Prepared in cooperation with the National Park Service

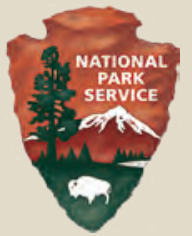

\title{
Occurrence and Distribution of Organic Wastewater Compounds in Rock Creek Park, Washington, D.C., 2007-08
}

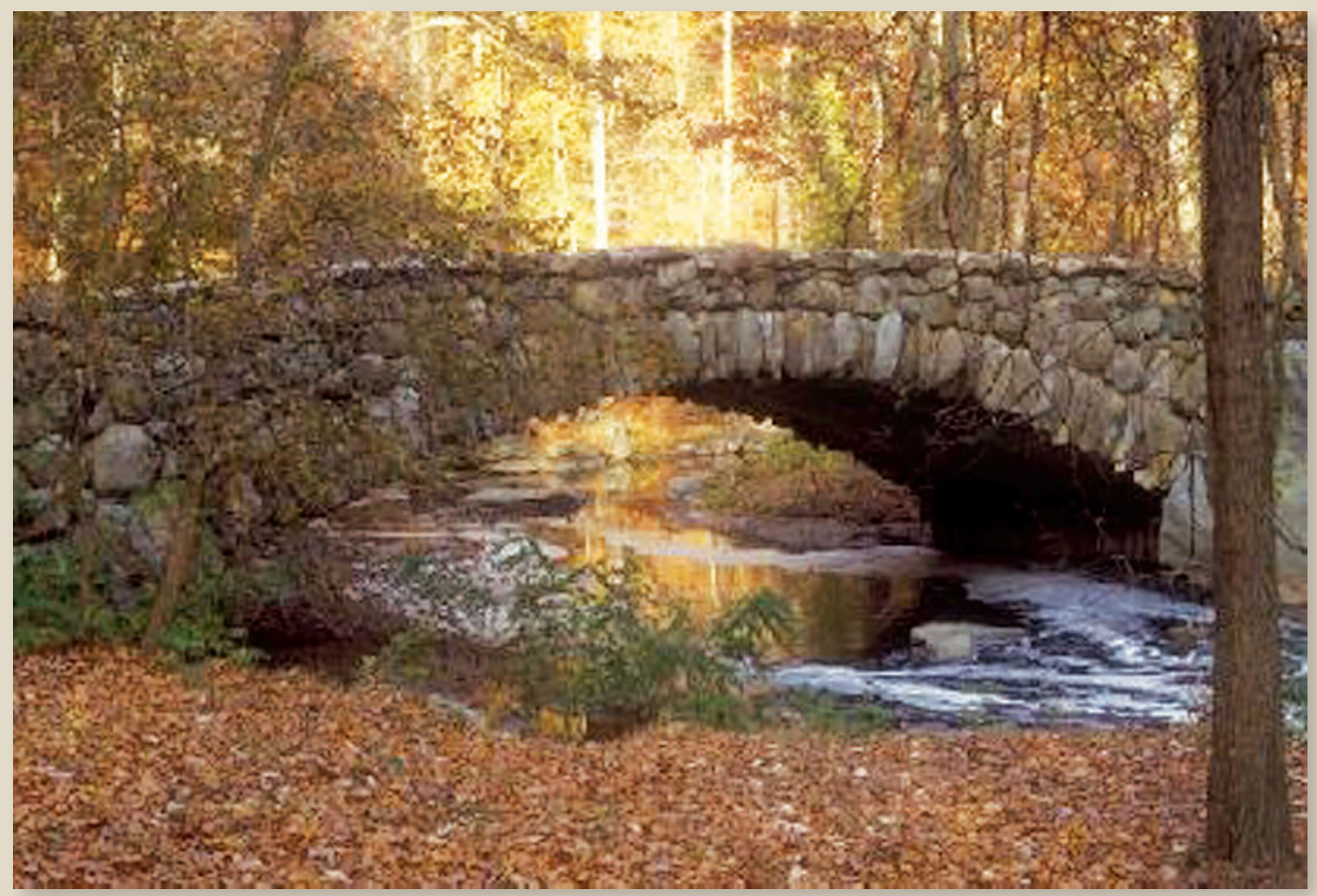

Scientific Investigations Report 2010-5162 
Cover. Boulder Bridge, Rock Creek Park, Washington, D.C. [Photograph by National Park Service.] 


\section{Occurrence and Distribution of Organic Wastewater Compounds in Rock Creek Park, Washington, D.C., 2007-08}

By Daniel J. Phelan and Cherie V. Miller

Prepared in cooperation with the

National Park Service

Scientific Investigations Report 2010-5162 


\section{U.S. Department of the Interior \\ KEN SALAZAR, Secretary \\ U.S. Geological Survey \\ Marcia K. McNutt, Director}

U.S. Geological Survey, Reston, Virginia: 2010

For more information on the USGS - the Federal source for science about the Earth, its natural and living resources, natural hazards, and the environment, visit http://www.usgs.gov or call 1-888-ASK-USGS

For an overview of USGS information products, including maps, imagery, and publications, visit http://www.usgs.gov/pubprod

To order this and other USGS information products, visit http://store.usgs.gov

Any use of trade, product, or firm names is for descriptive purposes only and does not imply endorsement by the U.S. Government.

Although this report is in the public domain, permission must be secured from the individual copyright owners to reproduce any copyrighted materials contained within this report.

Suggested citation:

Phelan, D.J., and Miller, C.V., 2010, Occurrence and distribution of organic wastewater compounds in Rock Creek Park, Washington, D.C., 2007-08: U.S. Geological Survey Scientific Investigations Report 2010-5162, 68 p. 


\section{Contents}

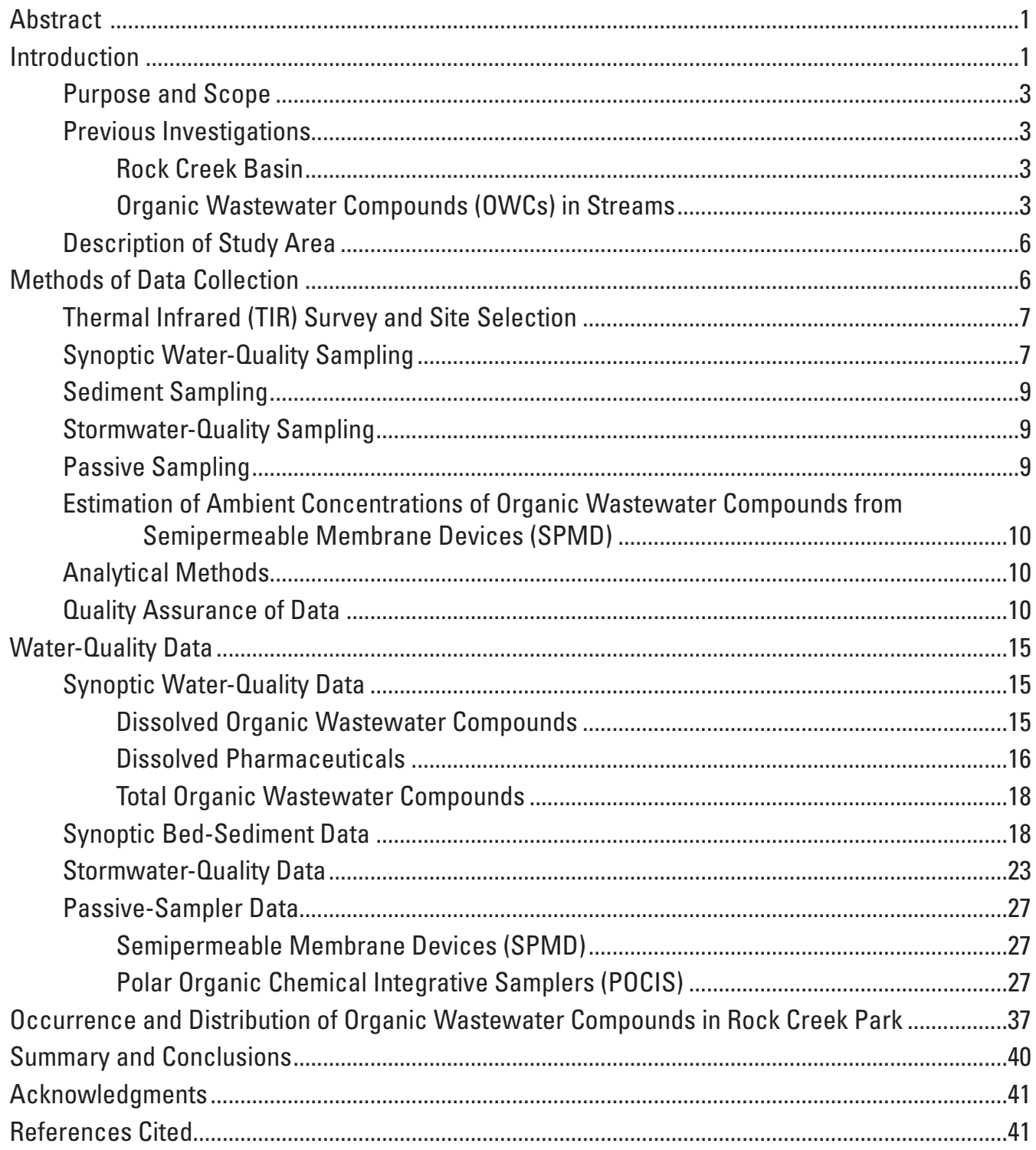


Appendix A: Selected images from thermal infrared flyover of Rock Creek Park, Washington, D.C., at dawn, January 31, 2007.

Appendix B: Organic wastewater compounds analyzed in filtered surface-water samples from Rock Creek Park, Washington, D.C., June 27-28, 2007. 48

Appendix C: Organic wastewater compounds for which surface-water samples were analyzed in unfiltered water in Rock Creek Park, Washington, D.C., June 27-28, 2007.

Appendix D: Organic wastewater compounds for which creek-bottom-sediment samples were analyzed in Rock Creek Park, Washington, D.C., June 27-28, 2007.

Appendix E: Concentrations of organic wastewater compounds in stormwater samples from Rock Creek at Joyce Road, Washington, D.C.

(station number 01648010), June and September 2008.

Appendix F: Concentrations of organic wastewater compounds from Semipermeable Membrane Devices (SPMD) in Rock Creek Park, Washington, D.C., July 2-29, 2008.

Appendix G: Concentrations of pesticides from Semipermeable Membrane Devices (SPMD) in Rock Creek Park, Washington, D.C., July 2-29, 2008.

\section{Figures}

1-3. Maps showing-

1. Location of Rock Creek drainage basin and Rock Creek Park study area, Washington, D.C...

2. Locations of surface-water sampling stations within the Rock Creek Park study area, Washington, D.C., 2007-08

3. Generalized location of areas that are served by a combined sewer system in Washington, D.C.

4-6. Graphs showing-

4. Long-term average discharge and daily mean discharge from October 2006 through September 2008 at Rock Creek at Sherrill Drive, Rock Creek Park, Washington, D.C.

5. Discharge and sample times from Rock Creek at Joyce Road, Washington, D.C., (A) June 27-28, 2008 and (B) September 6-7, 2008

6. Discharge and concentrations of total organic carbon (TOC), suspended sediment, caffeine, and DEET from Rock Creek at Joyce Road, Washington, D.C., (A) June 27-28, 2008 and (B) September 6, 2008 


\section{Tables}

1. Station numbers and names, and sample-collection dates for organic wastewater compounds from Rock Creek Park, Washington, D.C., 2007-08.

2. Concentrations of total organic carbon, and dissolved organic wastewater compounds detected in water from Rock Creek Park, Washington, D.C., June 27-28, 2007.

3. Summary of dissolved organic wastewater compounds detected at concentrations above method reporting levels in samples from Rock Creek Park, June 27-28, 2007

4. Concentrations of dissolved pharmaceuticals in water samples from Rock Creek Park, Washington, D.C., June 27-28, 2007

5. Summary of total organic wastewater compounds detected in water samples from Rock Creek Park, during base-flow synoptic, June 27-28, 2007

6. Concentrations of total organic wastewater compounds detected in water from Rock Creek Park, Washington, D.C., during base-flow synoptic, June 27-28, 2007.

7. Concentrations of organic wastewater compounds detected in creek bottom sediment, Rock Creek Park, Washington, D.C., during base-flow synoptic, June 27-28, 2007

8. Summary of dissolved-and total-organic-wastewater-compound concentrations in stormwater samples collected from Rock Creek at Joyce Road, Washington, D.C. (station number 01648010), June and September 2008.

9. Organic wastewater compounds that were detected in stormwater samples at Joyce Road that also were detected at each of the seven sediment-sampling sites

10. Concentrations of pharmaceuticals and antibiotics in stormwater samples collected from Rock Creek at Joyce Road, Washington, D.C., June 27 and September 6, 2008.

11. Estimated average water concentrations from the Semipermeable Membrane Devices (SPMD) deployed in Rock Creek Park, Washington, D.C., July 2 through 29, 2008

12. Normalized concentrations of organic wastewater compounds and pharmaceuticals detected in Polar Organic Chemical Integrative Samplers (POCIS) from five sites in Rock Creek Park, Washington, D.C., July 2 through 29,2008

13. Concentrations of pharmaceuticals and antibiotics from Polar Organic Chemical Integrative Samplers (POCIS) samples collected at two sites in Rock Creek Park, Washington, D.C., July 2 through 29, 2008 


\section{Conversion Factors and Datum}

\begin{tabular}{|c|c|c|}
\hline Multiply & By & To obtain \\
\hline \multicolumn{3}{|c|}{ Length } \\
\hline inch (in.) & 2.54 & centimeter $(\mathrm{cm})$ \\
\hline foot (ft) & 0.3048 & meter $(\mathrm{m})$ \\
\hline yard (yd) & 0.9144 & meter $(\mathrm{m})$ \\
\hline mile (mi) & 1.609 & kilometer $(\mathrm{km})$ \\
\hline \multicolumn{3}{|c|}{ Area } \\
\hline square foot $\left(\mathrm{ft}^{2}\right)$ & 0.09290 & square meter $\left(\mathrm{m}^{2}\right)$ \\
\hline square inch $\left(\mathrm{in}^{2}\right)$ & 6.452 & square centimeter $\left(\mathrm{cm}^{2}\right)$ \\
\hline square mile $\left(\mathrm{mi}^{2}\right)$ & 2.590 & square kilometer $\left(\mathrm{km}^{2}\right)$ \\
\hline \multicolumn{3}{|c|}{ Volume } \\
\hline gallon (gal) & 3.785 & liter (L) \\
\hline cubic foot $\left(\mathrm{ft}^{3}\right)$ & 0.02832 & cubic meter $\left(\mathrm{m}^{3}\right)$ \\
\hline \multicolumn{3}{|c|}{ Flow rate } \\
\hline cubic foot per second $\left(\mathrm{ft}^{3} / \mathrm{s}\right)$ & 0.02832 & cubic meter per second $\left(\mathrm{m}^{3} / \mathrm{s}\right)$ \\
\hline cubic foot per day $\left(\mathrm{ft}^{3} / \mathrm{d}\right)$ & 0.02832 & cubic meter per day $\left(\mathrm{m}^{3} / \mathrm{d}\right)$ \\
\hline gallon per minute (gal/min) & 0.06309 & liter per second (L/s) \\
\hline gallon per day (gal/d) & 0.003785 & cubic meter per day $\left(\mathrm{m}^{3} / \mathrm{d}\right)$ \\
\hline
\end{tabular}

Temperature in degrees Celsius $\left({ }^{\circ} \mathrm{C}\right)$ may be converted to degrees Fahrenheit $\left({ }^{\circ} \mathrm{F}\right)$ as follows:

$$
{ }^{\circ} \mathrm{F}=\left(1.8 \times{ }^{\circ} \mathrm{C}\right)+32
$$

Vertical coordinate information is referenced to the North American Vertical Datum of 1988 (NAVD 88).

Specific conductance is given in microsiemens per centimeter at 25 degrees Celsius $(\mu \mathrm{S} / \mathrm{cm}$ at $\left.25^{\circ} \mathrm{C}\right)$.

Concentrations of chemical constituents in water are given in either milligrams per liter (mg/L) or micrograms per liter $(\mu \mathrm{g} / \mathrm{L})$.

The term "water year" is defined as the 12-month period from 0ctober 1 of any given year through September 30 of the following year. The water year is designated by the calendar year in which it ends and which includes 9 of the 12 months. Thus, the year ending September 30, 1999 , is called the "1999" water year. 




\title{
Occurrence and Distribution of Organic Wastewater Compounds in Rock Creek Park, Washington, D.C., 2007-08
}

\author{
By Daniel J. Phelan and Cherie V. Miller
}

\section{Abstract}

The U.S. Geological Survey, and the National Park Service Police Aviation Group, conducted a high-resolution, low-altitude aerial thermal infrared survey of the Washington, D.C. section of Rock Creek Basin within the Park boundaries to identify specific locations where warm water was discharging from seeps or pipes to the creek. Twenty-three stream sites in Rock Creek Park were selected based on the thermal infrared images. Sites were sampled during the summers of 2007 and 2008 for the analysis of organic wastewater compounds to verify potential sources of sewage and other anthropogenic wastewater. Two sets of stormwater samples were collected, on June 27-28 and September 6, 2008, at the Rock Creek at Joyce Road water-quality station using an automated sampler that began sampling when a specified stage threshold value was exceeded. Passive-sampler devices that accumulate organic chemicals over the duration of deployment were placed in July 2008 at the five locations that had the greatest number of detections of organic wastewater compounds from the June 2007 base-flow sampling.

During the 2007 base-flow synoptic sampling, there were ubiquitous low-level detections of dissolved organic wastewater indicator compounds such as DEET, caffeine, HHCB, and organophosphate flame retardants at more than half of the 23 sites sampled in Rock Creek Park. Concentrations of DEET and caffeine in the tributaries to Rock Creek were variable, but in the main stem of Rock Creek, the concentrations were constant throughout the length of the creek, which likely reflects a distributed source. Organophosphate flame retardants in the main stem of Rock Creek were detected at estimated concentrations of 0.2 micrograms per liter or less, and generally did not increase with distance downstream. Overall, concentrations of most wastewater indicators in whole-water samples in the Park were similar to the concentrations found at the upstream sampling station at the Maryland/District of Columbia boundary. Polycyclic aromatic hydrocarbons were the dominant organic compounds found in the stormwater samples at the Joyce Road station. Polycyclic aromatic hydrocarbons were consistently found in higher concentrations either in sediment or in whole-water samples than in the dissolved samples collected during base-flow conditions at the 23 synoptic sites, or in the Joyce Road station stormwater samples.

\section{Introduction}

Rock Creek Park is located in north-central Washington, D.C., and is operated by the National Park Service (NPS) (fig. 1). Rock Creek may be affected by a decaying wastewater infrastructure that results in contamination from potentially leaking sewer lines that are exposed at stream crossings or along the banks of Rock Creek and its tributaries, or from sewer lines leaking into the local shallow, unconfined groundwater around the creek. A combined sewer system in part of Washington, D.C. also contributes sewage to Rock Creek when large storms contribute rainfall to the system that can overwhelm its capacity, resulting in sanitary-sewer discharges. Contamination from sewage sources by any mechanism is problematic to the health of the aquatic resources in the river and to the safety of local residents and park visitors, and therefore is of concern to the Park staff. In 2006, the U.S. Geological Survey (USGS) partnered with the NPS to conduct a study to investigate possible hydraulic connections between leaky sewer lines and the creek using thermal infrared (TIR) techniques to locate seeps, and active and passive waterquality sampling techniques to characterize the seeps that were identified. Water samples were collected and analyzed for the presence of organic wastewater compounds (OWCs) that can indicate the presence of untreated sewage. This is the third joint USGS-NPS study to investigate sources of impairment to Rock Creek in Washington, D.C. 


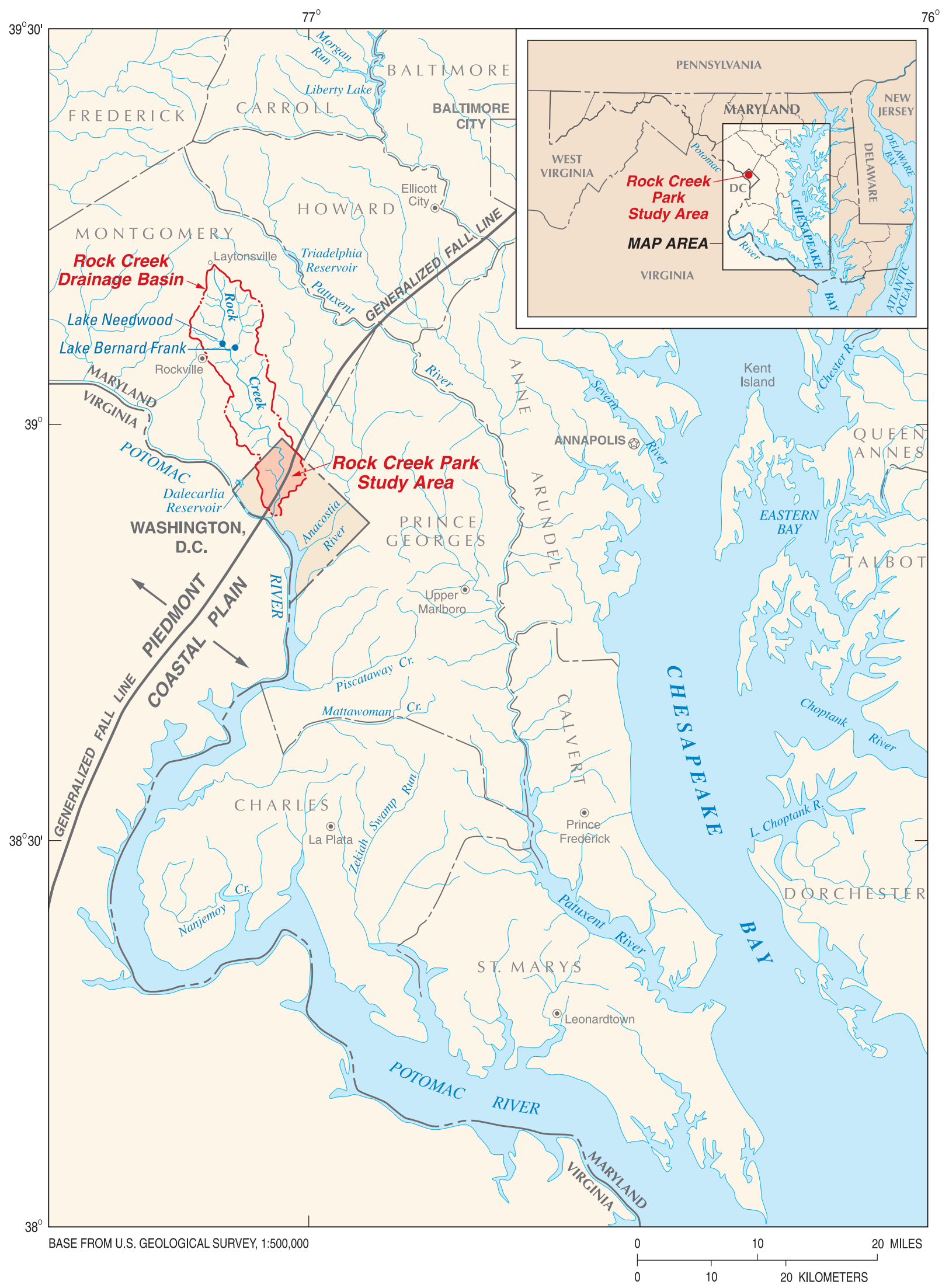

Figure 1. Location of Rock Creek drainage basin and Rock Creek Park study area, Washington, D.C. (from Anderson, 2002). 


\section{Purpose and Scope}

The purpose of this report is to describe the results of investigations of potentially leaky sewer lines or groundwater seeps in Rock Creek Park in Washington, D.C. from January 2007 through September 2008. The report describes the TIR technique used in January 2007 to locate areas where warm groundwater was seeping into the creek and identifies their origin, such as groundwater seeps, discharging pipelines, or leaky pipelines. On the basis of the TIR results, samples were collected in June 2007 at 23 sites in the basin and were analyzed for OWCs (fig. 2). Five of the sites with the highest number of detections of OWCs were selected for monitoring using passive sampling methods over a 4-week period in July 2008. Sequential samples were collected over two storm cycles in the summer of 2008 at the monitoring site at Joyce Road (fig. 2) and analyzed for concentrations of OWCs (antimicrobials, fragrances, surfactants, fire retardants, etc.).

\section{Previous Investigations}

This section describes previous investigations that were conducted at both local and national scales. The first section describes investigations in the Rock Creek Basin, and the second section presents the recent history of national studies on OWCs in streams.

\section{Rock Creek Basin}

One of the earliest published reports on the water quality of Rock Creek was by Sherman and Horner (1935), who documented contamination as indicated by biological oxygen demand (BOD) and coliform bacteria in the stream from the Maryland/Washington, D.C. boundary to the mouth at the Potomac River. On the basis of Sherman and Horner's recommendations, improvements to sewer infrastructures were instituted, and as documented by CH2M HILL (1977, 1979), stream conditions have improved, but the stream remains affected by contamination. Fecal-indicator bacteria and other indicators of sewage contamination persist, particularly in the lower reaches of the stream. In 1979, CH2M HILL conducted a survey of undocumented outfalls on the main stem and tributaries of Rock Creek, and documented a number of these outfalls that were discharging waters with elevated levels of fecal coliforms and chemical oxygen demand (COD). Concentrations of iron, lead, zinc, and mercury in bed sediment also were measured in that survey, but none of those concentrations exceeded any action levels for that period.

The effects of urbanization on streamflow and sediment transport in the Rock Creek and Anacostia River Basins of Montgomery County, Maryland from 1962-74 were described by York and Herb (1978). The USGS collected water- and sediment-quality samples and analyzed for pesticides and organic compounds within Rock Creek Park during 19992000 (Anderson and others, 2002). In Anderson's temporal assessment of water quality at one site on the main stem of Rock Creek, concentrations of four insecticides - chlorpyrifos, diazinon, carbaryl, and malathion - were found to exceed published guidelines for the protection of aquatic life year-round. Several major classes of chemicals also were found in samples of bed sediment from the three locations that were sampled on the main stem of Rock Creek. Most of the chemicals and compounds analyzed were detected in the bed sediment. Concentrations of 8 trace metals, 13 polycyclic aromatic hydrocarbons (PAHs), 7 organochlorine (OC) pesticides, total polychlorinated biphenyls (PCBs), and 1 phthalate compound were found to exceed published guidelines for the protection of aquatic life (U.S. Environmental Protection Agency, 1999; Canadian Council of Ministers of the Environment, 2007; International Joint Commission of the Unites States and Canada, 1989). Miller and others (2006) described the chemical and ecological health of white sucker, a benthic-feeding fish, during 2003-04 in the Rock Creek Basin of Washington, D.C., and found anecdotal evidence of contaminant effects on the fish.

\section{Organic Wastewater Compounds (OWCs) in Streams}

The USGS has pioneered new analytical techniques to measure OWCs in aquatic environments. Kolpin and others (2002) documented and compared new analytical methods and reported results for a reconnaissance of 95 OWCs in 139 streams across the United States. During 1999 and 2000, they focused on sites that were most likely to be influenced by upstream sources of wastewater, such as watersheds with intense urbanization and livestock production. The compounds most frequently detected in their study were coprostanol (a fecal steroid), cholesterol (a plant and animal steroid), DEET ( $N, N$-Diethyl-meta-toluamide, a broadly used insect repellant), caffeine (a stimulant produced in plants grown primarily in tropical regions and thus not found naturally in temperate zone streams), triclosan (a common antimicrobial disinfectant in hand soap and other household products), tris(2-chloroethyl)phosphate (a fire retardant), and 4-nonylphenol (a nonionic detergent metabolite). One or more OWCs were found in 80 percent of the streams sampled, but few concentrations exceeded drinking-water criteria or aquatic-life guidelines. Total summed concentrations of the OWCs commonly exceeded $1 \mu \mathrm{g} / \mathrm{L}$ (microgram per liter) and the maximum total concentration was $57.3 \mu \mathrm{g} / \mathrm{L}$, indicating that further study may be needed on the biological and human-health effects of mixtures of OWCs in drinking-water sources.

A follow-up study by Kolpin and others (2004) compared upstream and downstream concentrations of OWCs at 10 urban locations in Iowa during low-, normal-, and high-flow conditions. Their results indicated that the likely source of beta-sitosterol was decaying plant materials (from both natural sources and paper products). The anti-convulsive carbamazepine was the most commonly detected pharmaceutical 


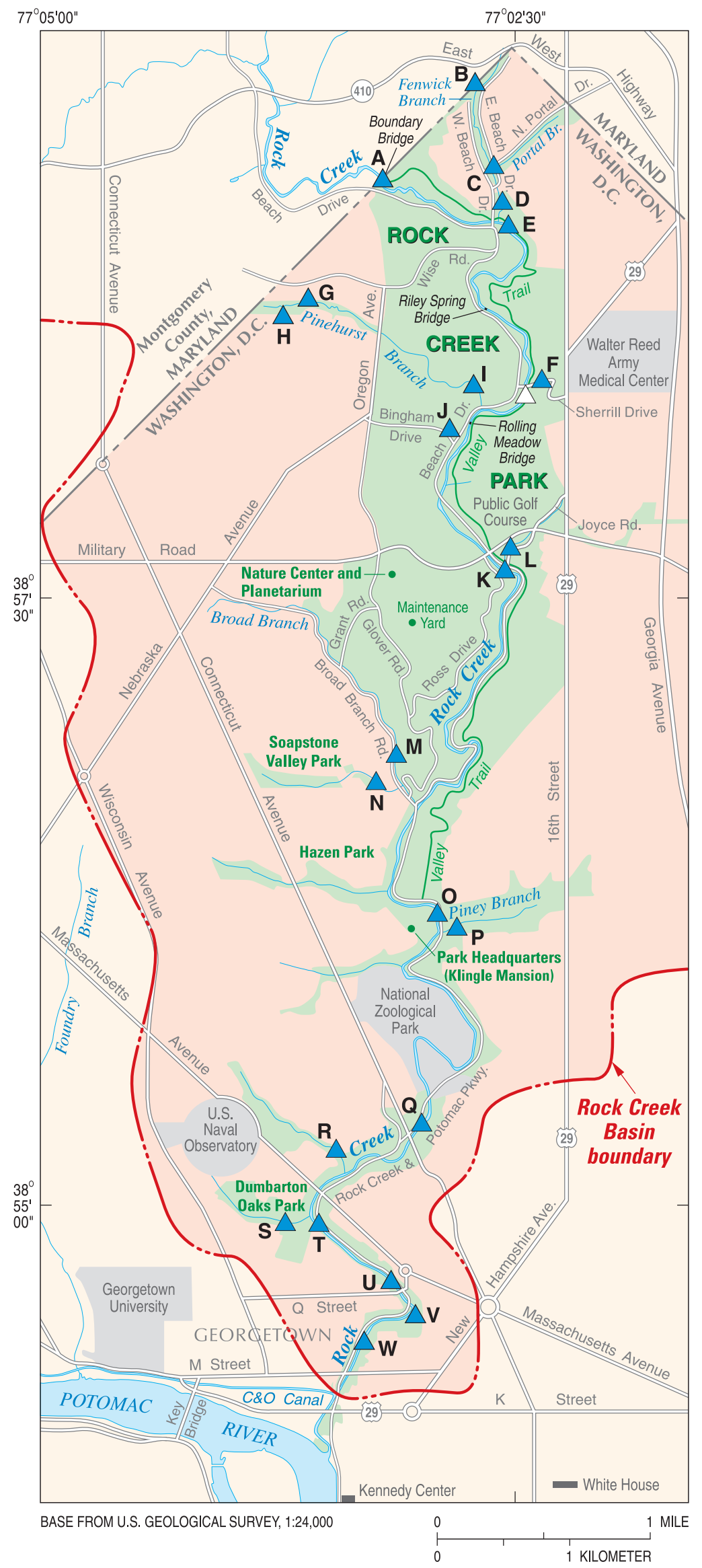

\begin{tabular}{|ccl|}
\hline $\begin{array}{c}\text { Map } \\
\text { letter }\end{array}$ & $\begin{array}{c}\text { Station } \\
\text { number }\end{array}$ & \multicolumn{1}{c|}{ Station name } \\
\hline A & 01647994 & Rock Creek at Maryland/D.C. boundary \\
B & 01647996 & Tributary to Fenwick Branch at Red Bud Ln. \\
C & 01647997 & Portal Branch at Fenwick Branch \\
D & 0164799789 & Fenwick Branch above Rock Creek \\
E & 0164799790 & Storm sewer to Rock Cr. below Fenwick Br. \\
F & 01648001 & Whittier Run above Rock Creek \\
G & 01648002 & Pinehurst Branch above Barnaby Street \\
H & 01648003 & Pinehurst Branch tributary near Barnaby St. \\
I & 01648005 & Pinehurst Branch at Beach Drive \\
J & 0164800550 & Rock Creek tributary near Bingham Drive \\
K & 01648010 & Rock Creek at Joyce Road \\
L & 01648011 & Luzon Branch at Joyce Road \\
M & 0164801540 & Broad Branch above Soapstone Valley \\
N & 0164801550 & Soapstone Valley tributary to Broad Branch \\
O & 01648100 & Rock Creek above Piney Branch \\
P & 01648200 & Piney Branch above Rock Creek \\
O & 01648300 & Rock Creek above Connecticut Avenue \\
R & 01648390 & Normanstone Creek above Rock Creek \\
S & 01648450 & Dumbarton Oaks tributary above Rock Cr. \\
T & 01648500 & Rock Creek below Dumbarton Oaks Park \\
U & 01649000 & Rock Creek at Q Street \\
V & 01649003 & Pipe inflow to Rock Creek below P Street \\
W & 01649010 & Rock Creek above M Street \\
\hline & & \\
\hline
\end{tabular}

\section{EXPLANATION}

ROCK CREEK PARK

ROCK CREEK PARK STUDY AREA

A SURFACE-WATER SAMPLING STATION AND MAP LETTER

$\triangle$ ROCK CREEK AT SHERRILL DRIVE GAGE (USGS STATION NUMBER 01648000)

Figure 2. Locations of surface-water sampling stations within the Rock Creek Park study area, Washington, D.C., 2007-08. 
compound, and urban contributions to OWCs at sites in their study decreased during higher flows likely due to dilution. They found a significant relation between the ratio of population over stream discharge to total concentrations of OWCs, indicating that an increase in population per unit of flow corresponded to an increase in the occurrence and concentrations of OWCs.

Glassmeyer and others (2005) conducted a study of a stream transect that passed by a wastewater-treatment plant outfall and found results of the occurrence of OWCs similar to those in the earlier studies by Kolpin and others (2002, 2004). Coprostanol/cholesterol ratios in effluent (0.66) and two downstream samples of the wastewater-treatment plant (WWTP) (0.55 and 0.48) were similar to those found in human fecal material, indicating that this ratio is a good indicator of human waste. Flame retardants and fecal and plant sterols were the most commonly detected compounds. Glassmeyer and others (2005) found that benzophenone, ethyl citrate, HHCB (galaxolide), tributyl phosphate, and triclosan were indicators of human waste-stream contamination because they were scarce or below detection levels upstream from the WWTPs, were found in almost all WWTP effluents, and were present in lower concentrations in downstream samples. An interesting approach in this study was a comparison of the ratios of ephemeral (easily degraded) compounds (HHCB and ATHN (tonalide), intermediately persistent ones (coprostanol and triclosan), and recalcitrant ones (carbamazepine and DEET). When ephemeral compounds were compared to more persistent compounds, there was a dramatic decrease in the ratios moving downstream from the WWTP, providing a further weight of evidence as to their source.

In another national study by USGS (Focazio and others, 2008), 25 groundwater and 49 surface-water sites that are sources of drinking water were sampled for the occurrence of 100 targeted OWCs. The five most frequently detected chemicals in surface water were cholesterol, metolachlor, cotinine, beta-sitosterol, and 1,7-dimethylxanthine, and the five most frequently detected chemicals in groundwater were trichloroethene (TCE), carbamazepine, bisphenol-A, 1,7-dimethylxanthine, and tris(2-chloroethyl)phosphate. Carbamazepine and DEET are not efficiently removed by commonly used wastewater-treatment processes, and carbamazepine was the most commonly detected pharmaceutical in both surface water and groundwater. Pesticides, fragrances and flavors, steroids, non-prescription drugs, plasticizers, flame retardants, and detergent metabolites were detected more frequently than prescription pharmaceutical compounds. Barnes and others (2008) also published results from a national reconnaissance of 47 groundwater sites that were susceptible to wastewater contamination, testing for 65 OWCs. Their most frequently detected compounds were DEET, bisphenol A, tris(2-chloroethyl)phosphate, sulfamethoxazole, and 4-octylphenol monoethoxylate. They observed that, in general, OWCs have a lower frequency of occurrence in groundwater than in surface water, and the number of detections tends to decrease with increasing well depth.
Barber and others (2006) measured inorganic and organic stream chemical loading along a land-use gradient in Boulder Creek, Colorado, and found that the most abundant OWCs were ethylenediaminetetraacetic acid (EDTA), nonylphenolethoxycarboxylic acids (NPEC), and coprostanol. They observed a steep increase in coprostanol, triclosan, caffeine, and nonylphenol below a WWTP, and found that the concentrations of gadolinium increased with the concentrations of OWCs and WWTP discharge. Concentrations of lithium, used as a mood stabilizer and for the treatment of bipolar disorder, also correlated positively to concentrations of OWCs and probably had a medical source. Concentrations of OWCs increased along the population and land-use gradients. Caffeine was a good indicator of population along the stream gradient, but triclosan was only detected in the headwaters and just below the WWTP.

Caffeine, HHCB, and nicotine derivatives have been used successfully in many applications as markers of wastewater contamination to surface and groundwaters (Buerge and others, 2003, 2006, 2008; Bradley and others, 2007; Weigel and others, 2004). The environmental occurrence of caffeine that is naturally present in many tropical plant species can largely be attributed to human-waste sources in temperate zones. Nicotine cannot be exclusively attributed to human waste, as it has natural plant sources, largely from the cultivation of tobacco in the Southeast and Mid-Atlantic regions of the United States. However, cotinine is a metabolite of nicotine produced in the mammalian liver, so it is a good indicator of wastewater. Bradley and others (2007) used microcosms to study the potential biotransformation and degradation of cotinine and caffeine in river sediments. They found substantial transformations of these compounds and determined that although their presence may be a strong indicator of wastewater sources, their absence cannot be interpreted as a lack of these sources.

Phillips and Chalmers (2009) used the occurrence of certain groups of chemicals to differentiate between combined sewer overflows (CSOs) and WWTP effluents in urban streams. Concentrations of chemicals that are removed or degraded in the wastewater-treatment processes (caffeine, TCPP, and cholesterol) increase during storm events due to CSOs that contribute untreated water during the storm. Concentrations of chemicals that are not effectively removed in the process are higher in the WWTP effluents and therefore are higher during base flow and are diluted during storm events. Chemicals that have other sources, such as agricultural pesticides, have maximum concentrations at sites distant from WWTP effluents and CSO outfalls. The number of PAHs detected and the concentrations of individual PAHs were generally higher in urban streams and related to CSO outfalls, probably reflecting contributions from street runoff. Concentrations of fluoranthene, methylnaphthalene, 2,6-dimethylnaphthalene, 2-methylnaphthalene, phenanthrene, and pyrene were similar. Other studies have recently directly linked urban loadings of PAHs to coal-tar parking-lot sealants, showing that this one source is by far the most prevalent in urban runoff (Van Metre and Mahler, 2005). 
Results from these and other studies have consistently found OWCs in many streams across the United States, often at locations that are near potential sources, and sometimes farther from wastewater influences. The concentrations are usually low, but not always. Pharmaceutical compounds are detected less frequently than other groups of OWCs, and generally are found closer to potential sources. Often multiple compounds are found in each sample, and the biological and health effects at ambient concentrations are relatively unknown. Many recent studies are focusing on detection and concentration behavior of OWCs, as they are processed through WWTPs and along stream gradients as well. As the chemical properties differ widely among OWCs, presence/ absence and changes in concentrations can be used as tracers of specific sources. Different OWCs can be very specific markers of the type of contamination, such as raw or treated sewage effluent.

\section{Description of Study Area}

The Rock Creek study area (fig. 1) is a heavily urbanized basin within the Potomac River Basin. The creek channel winds approximately $33 \mathrm{mi}$ (miles) from its source near Laytonsville, Maryland, to the Potomac River (CH2M Hill, 1979). Rock Creek and the Chesapeake and Ohio (C\&O) Canal converge $0.25 \mathrm{mi}$ upstream from the Potomac River (fig. 2). The C\&O Canal drains a small part of southern Montgomery County, Maryland, and discharges to Rock Creek. Therefore, for the purposes of this report, the Rock Creek Basin ends at its junction with the C\&O Canal. The Rock Creek Basin drains approximately $76.5 \mathrm{mi}^{2}$ (square miles) in both Maryland and Washington, D.C., of which approximately $18 \mathrm{mi}^{2}$ are within Washington, D.C. The NPS manages 2,118 acres within the Rock Creek Basin of Washington, D.C. (CH2M Hill, 1979; fig. 1).

Streamflow in Rock Creek has been measured at a USGS streamflow gaging station at Sherrill Drive (station number 01648000) from October 1929 through the present (2010) (fig. 2). The drainage area above the gage is $62.2 \mathrm{mi}^{2}$. The annual mean discharge at Sherrill Drive from 1930 through 2008 was $64.3 \mathrm{ft}^{3} / \mathrm{s}$ (cubic feet per second), and ranged from a maximum of $142 \mathrm{ft}^{3} / \mathrm{s}$ in 1972 to a minimum of $16.1 \mathrm{ft}^{3} / \mathrm{s}$ in 1931. Annual mean discharge for the 2007 water year (October 1, 2006-September 30, 2007) was $54.4 \mathrm{ft}^{3} / \mathrm{s}$, and annual mean discharge for the 2008 water year (October 1 , 2007-September 30, 2008) was $57.6 \mathrm{ft}^{3} / \mathrm{s}$ (U.S. Geological Survey, 2009). Runoff for Rock Creek was only slightly below average during the period of this study compared to the period of record, and runoff during the 2 years of this investigation was similar.

The Rock Creek Basin lies almost entirely within the upland section of the Piedmont Physiographic Province. The rocks are metamorphosed sedimentary and igneous rocks of Cambrian to Ordovician age that have been intensely folded and deformed so that there is negligible intergranular porosity
(Duigon and others, 2000). The primary types of bedrock in the basin are complex schists, tonalites, and granodiorites (Darton, 1950). The most detailed geologic investigation of the Rock Creek Basin in Washington, D.C. is by Fleming and others (1994).

Washington, D.C. is supplied with drinking water by the U.S. Army Corps of Engineers Washington Aqueduct, which withdraws water from the Potomac River. Many of the areas of Montgomery County in the Rock Creek Basin are supplied with water by the Washington Suburban Sanitary Commission (WSSC), which withdraws water from both the Potomac and Patuxent Rivers (fig. 1). There are no major water withdrawals from the Rock Creek Basin; however, there are small users, homeowners, and farms that use private wells for supplies in the northern reaches of the basin in Maryland. There are no WWTPs in the Rock Creek Basin in either Montgomery County or Washington, D.C.; however, some areas in Montgomery County are served by small or privately owned septic systems. Even though there are no public water withdrawals from the basin, or public-treated wastewater discharges to the basin, there is an unmeasureable net gain of water from outside the basin because all public water used in the basin is supplied from outside the basin. Not all of the water delivered to the basin discharges to the public wastewater systems (due to lawn watering, car washing, fire hydrant use, and leaky water and sewer lines).

About one third of the $60-\mathrm{mi}^{2}$ area of Washington, D.C. is served by a combined sewer system (CSS) that routes both rainwater and municipal sewage through the same pipes to the Blue Plains Wastewater Treatment Plant (fig. 3). When flow exceeds the maximum capacity of the CSS during storms, untreated wastewater discharges from the CSS to the creeks that eventually drain to the Potomac and Anacostia Rivers (District of Columbia Water and Sewer Authority, 2002). These releases or discharges are called CSOs and they can affect Rock Creek Park.

There are two flood-control reservoirs in the basin-Lake Needwood on Rock Creek, and Lake Bernard Frank on the North Branch of Rock Creek (fig. 1) - that have acted as sediment and nutrient traps since their construction in the 1960s (Duigon and others, 2000; Maryland-National Capital Park and Planning Commission, 1999). Both of these reservoirs are located in Montgomery County. Further information on the geology, hydrology, precipitation, and land-use patterns in the study area is given in Anderson and others (2002).

\section{Methods of Data Collection}

Prior to any water sampling, USGS and NPS personnel reviewed the design and layout of the combined stormwater/ wastewater system in Washington, D.C. to identify areas of sewer infrastructure that may discharge directly to Rock Creek. A thermal infrared (TIR) survey was conducted to identify locations where warm groundwater was entering the 


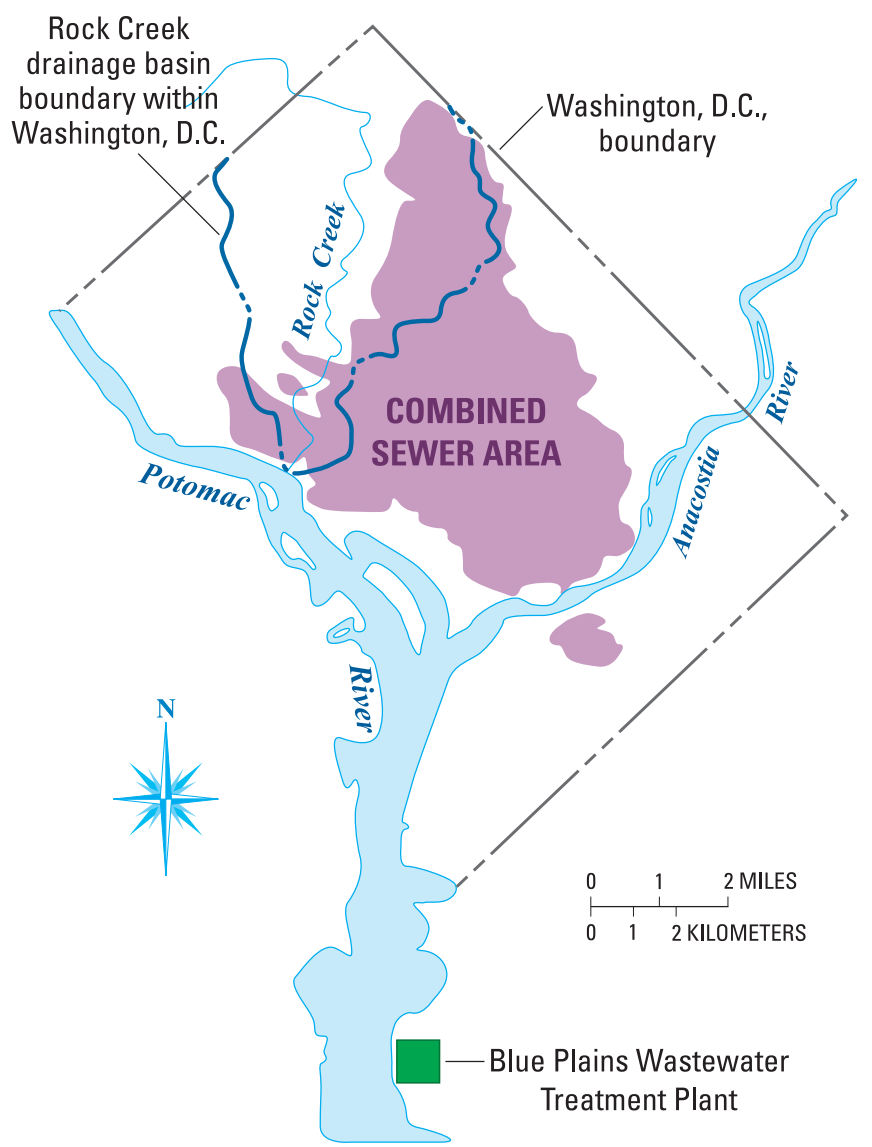

Figure 3. Generalized location of areas that are served by a combined sewer system in Washington, D.C. (modified from District of Columbia Water and Sewer Authority, 2002).

creek or its tributaries, and to determine if the source might be natural groundwater seeps, leaky water lines, or CSOs. Surface-water sampling sites were selected by the USGS and NPS on the basis of the results of the TIR survey. Sampling of these sites occurred in June 2007, and subsequent passive sampling occurred in 2008 based on the results of the base-flow sampling. The following sections describe the methods used to locate seeps and the selection of sampling sites.

\section{Thermal Infrared (TIR) Survey and Site Selection}

Aerial TIR imagery is an accurate, non-invasive screening tool for the identification of groundwater seeps or pipeline discharges over a large area. TIR imagery has been used as a remote sensing application to qualitatively and quantitatively assess temperature variation in natural systems, including groundwater discharge (Banks and others, 1996; Portnoy and others, 1998; Majcher and others, 2007).

The USGS worked with the National Park Service Police Aviation Group to conduct a high-resolution, low-altitude aerial TIR survey of the Washington, D.C. section of the Rock
Creek Basin and its tributaries within the park boundaries on January 31, 2007. Sources of error in TIR imagery in natural waters include reflective energy interference and thermal stratification (Majcher and others, 2007; Torgersen and others, 2001). TIR imagery does not differentiate between reflected and emitted thermal energy during daylight hours; therefore, solar interference can negatively affect the interpretation of images (Majcher and others, 2007). To minimize the undesired effects of reflection and the effect of solar heating of land or water surfaces during daylight, the TIR survey started just before dawn, and was completed while the creek and tributaries were still in shadows.

The helicopter and TIR camera are owned and operated by the National Park Service Police Aviation Group,

Washington, D.C. The TIR camera that was used was a FLIR model Star Safire 2 mounted under the nose of the helicopter. Data were downloaded from the helicopter data system and stored on DVDs.

Data from the TIR surveys helped identify specific locations where warm water was discharging to the creek. Many of the "warm spots" were the result of water flowing out from either storm-sewer outfalls or sections where small streams had been piped underground, causing localized warming of the discharge water. The identified warm spots were documented and reviewed by USGS and NPS hydrologists, and 23 sites were selected for sampling on the basis of those results. Examples of some of the TIR images are shown in Appendix A.

\section{Synoptic Water-Quality Sampling}

Surface-water samples were collected and analyzed for concentrations of OWCs during base-flow conditions in June 2007 at 23 sites in the basin (fig. 2). Water samples collected from all 23 sites were analyzed for dissolved OWCs and total organic carbon (TOC). Water and bed-sediment samples from seven of the sites also were analyzed for total OWCs (table 1).

Samples analyzed for dissolved and total OWCs were collected by dipping 1-L (liter) baked brown-glass bottles into the center of flow where the channel was narrow and the stream well mixed. Samples analyzed for TOC were collected by dipping a $250-\mathrm{mL}$ (milliliter) brown-glass bottle in the center of flow. All samples were shipped overnight to the USGS National Water Quality Laboratory (NWQL) in Denver, Colorado, on ice with no preservatives. Samples analyzed for dissolved constituents were filtered at the NWQL using a 0.7-micron glass-fiber filter and analyzed at the NWQL using polystyrene-divinylbenzene solid-phase extraction and capillary-column gas chromatography/mass spectrometry (GC/MS) (Zaugg and others, 2006). Samples analyzed for whole-water concentrations were analyzed at the NWQL using continuous liquid-liquid extraction and capillary-column GC/MS (Zaugg, Smith, and Schraeder, 2006). TOC samples were analyzed at the NWQL using high-temperature combustion method 5310B (Clesceri and others, 1999). 


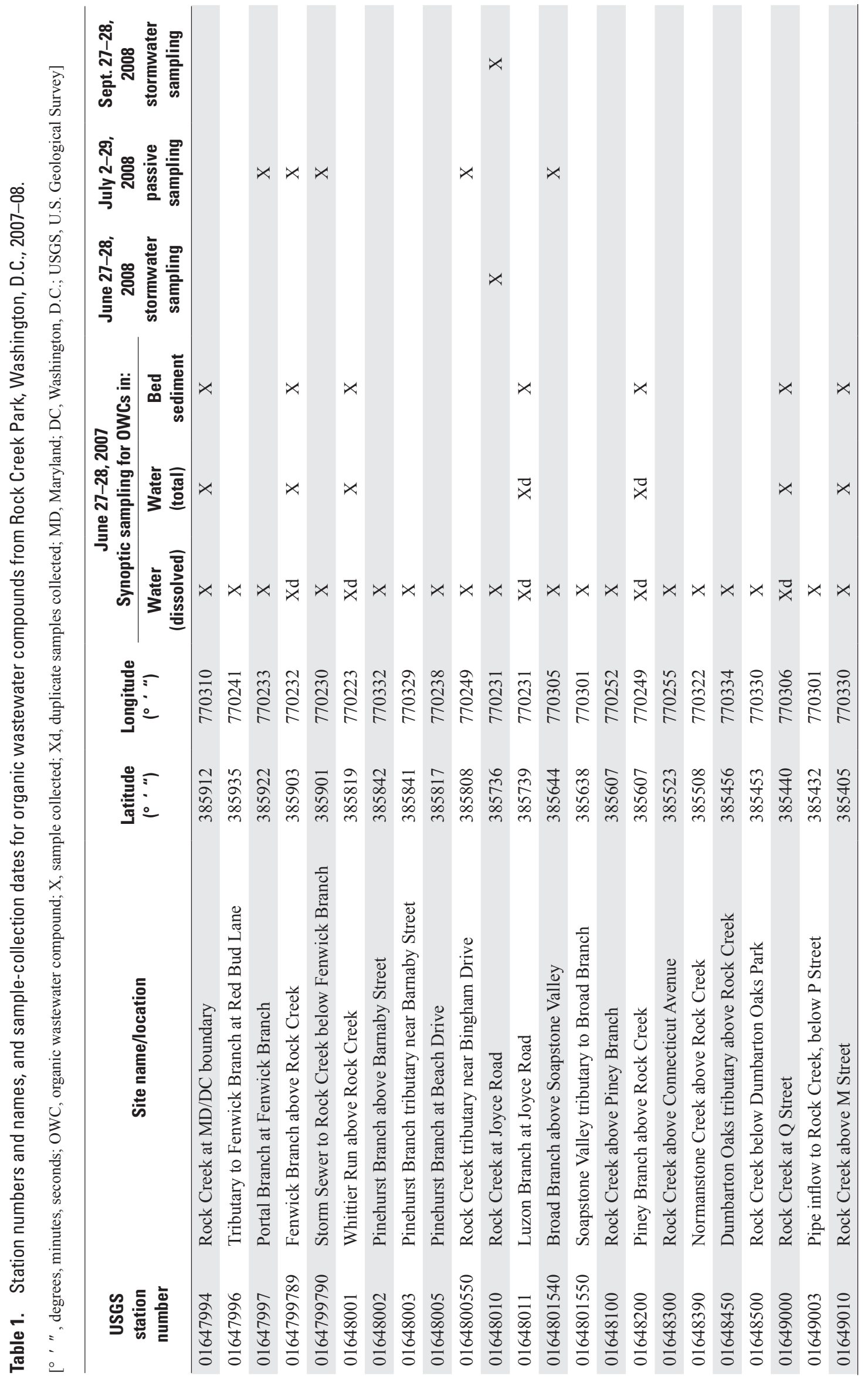




\section{Sediment Sampling}

Creek-bottom sediment samples were collected at seven sites and analyzed for concentrations of OWCs in the sediment (table 1). Sediment was scooped with clean stainless-steel trowels and placed in baked-glass jars. The goal in collecting bed samples is to capture primarily fine-grained sediments, on which organic compounds tend to adhere. At each of the seven sites, most sediment was primarily coarse sand to small gravel, with very little fine-grained material available due to the typical high-energy conditions of the stream channels. Samples were sent to the NWQL for analysis.

\section{Stormwater-Quality Sampling}

Stormwater samples were collected at the USGS gaging station at Rock Creek at Joyce Road (station number 01648010, fig. 2) using an automated refrigerated sampler (American Sigma 900Max) that began sampling when a specified stage threshold value was exceeded. Teflon-lined tubing was used between the creek and the sampler, and the peristaltic-pump tubing in the automated sampler was cleaned and sterilized between sampling events to prevent cross-contamination. Sets of three bottles per sample were collected at four different times during each storm. One of the three bottles was a sterile bottle for analysis of bacteria that was performed at the USGS office in Baltimore, Maryland. The other two bottles per set were composited and analyzed for either total or dissolved OWCs.

\section{Passive Sampling}

The potential for high variability in concentrations of OWCs in surface water exists if there are intermittent or ongoing releases from leaky sewer lines, CSOs, or shifts in sources during storm events. Passive samplers can accumulate the contaminants of interest over a period of weeks and are more likely to detect evidence of periodic or episodic releases than discrete sampling.

The two types of passive samplers used in this study were the pharmaceutical type of Polar Organic Chemical Integrative Samplers (POCIS) (Alvarez and others, 2004) and the Semipermeable Membrane Devices (SPMD) (Huckins and others, 2002). The POCIS are designed to sample watersoluble (polar or hydrophilic) organic chemicals from aqueous environments. The POCIS consists of a sorbent material between two microporous polyethersulfone membranes and samples chemicals from the dissolved phase (Alvarez and others, 2004, 2009). Sampling of compounds by the POCIS is integrative, and analyte concentrations are reported as accumulated concentrations over the period of deployment of the samplers. After deployment, the samplers were shipped to the Environmental Sampling Technologies (EST) lab in St. Joseph, Missouri, and the chemicals were extracted into methanol, then shipped to the NWQL for analysis. The NWQL performed a solvent exchange into methylene chloride prior to analysis.

The SPMD are designed to sample lipid- or fat-soluble (nonpolar or hydrophobic) semivolatile organic chemicals from water and air. The SPMD consists of a neutral, highmolecular-weight lipid [greater than 600 Daltons (Da)] such as triolein, which is encased in a thin-walled [50-100 $\mu \mathrm{m}$ (micrometers)] layflat polyethylene membrane tube. The nonporous membrane allows the nonpolar chemicals to pass through to the lipid where the chemicals are concentrated. These devices are designed to mimic the bioconcentration processes of living organisms and organic matter, which results in elevated contaminant concentrations after exposure to trace hydrophobic organic contaminants in aquatic environments (Alvarez and others, 2009). After deployment, the samplers were shipped to the EST lab and the chemicals were extracted using a dialytic extraction step into methylene chloride. Following dialysis, all sequestered chemicals are in the organic solvent (Huckins and others, 2002).

As both polar and non-polar compounds were detected in the June 2007 synoptic sampling, both types of passive samplers were required to ensure that all of the compounds of interest would be detected by the proper sampling device. Both passive samplers were developed by the USGS Columbia Environmental Research Center (CERC) in Columbia, Missouri, and are marketed for general use solely by EST of St. Joseph, Missouri.

POCIS and SPMD samplers were deployed at the five sites that had the highest number of detections and sum of concentrations during the June 2007 synoptic sampling effort. The samplers were deployed on July 2, 2008, and retrieved on July 29, 2008, at the following five sites (fig. 2):

\begin{tabular}{|c|c|c|c|}
\hline $\begin{array}{c}\text { U.S. } \\
\text { Geological } \\
\text { Survey } \\
\text { station } \\
\text { number }\end{array}$ & $\begin{array}{l}\text { Site name/ } \\
\text { location }\end{array}$ & $\begin{array}{l}\text { Number of } \\
\text { dissolved } \\
\text { compounds } \\
\text { detected }\end{array}$ & $\begin{array}{c}\text { Sum of con- } \\
\text { centrations } \\
\text { that were } \\
\text { greater than } \\
\text { estimated } \\
\text { concentrations } \\
\text { (micrograms } \\
\text { per liter) }\end{array}$ \\
\hline 01647997 & $\begin{array}{l}\text { Portal Branch at } \\
\text { Fenwick Branch }\end{array}$ & 16 & 2.2 \\
\hline 0164799789 & $\begin{array}{c}\text { Fenwick Branch } \\
\text { above Rock } \\
\text { Creek }\end{array}$ & 12 & 0.9 \\
\hline 0164799790 & $\begin{array}{l}\text { Storm Sewer outfall } \\
\text { to Rock Creek } \\
\text { below Fenwick } \\
\text { Branch }\end{array}$ & 21 & 0.7 \\
\hline 0164800550 & $\begin{array}{l}\text { Rock Creek } \\
\text { tributary near } \\
\text { Bingham Drive }\end{array}$ & 23 & 4.2 \\
\hline 0164801540 & $\begin{array}{c}\text { Broad Branch above } \\
\text { Soapstone Valley }\end{array}$ & 15 & 3.5 \\
\hline
\end{tabular}


The SPMD and POCIS samplers were constructed according to established procedures described in Alvarez and others (2007) and Huckins and others (2006). SPMD samplers were shipped from EST to the USGS Baltimore office in sealed steel cans on ice, and the units were kept on ice until deployment. POCIS devices were shipped from EST in sealed steel cans, but were not refrigerated. After retrieval, the devices were shipped overnight in the sealed steel containers to EST, and the SPMD were shipped on ice. The EST lab extracted the chemicals using a dialytic extraction step into methylene chloride. Following dialysis, all sequestered chemicals are in the organic solvent (Huckins and others, 2002). EST extracted the compounds into ampules and shipped the ampules to the NWQL for analysis of OWCs. Extractions from POCIS samples from the sites at Rock Creek at Bingham Drive and Fenwick Branch above Rock Creek were split at the EST lab, and a part of the split sample was sent to the USGS Organic Geochemistry Research Group Laboratory (OGRL) in Lawrence, Kansas, for analysis for antibiotics.

\section{Estimation of Ambient Concentrations of Organic Wastewater Compounds from Semipermeable Membrane Devices (SPMD)}

Average ambient concentrations of selected chemicals can be estimated from SPMD and POCIS integrative sampler concentrations using multiple assumptions for chemical equilibrium and physical processes. The regression models for concentrations from SPMD have been worked out by Alvarez and others $(2004,2007,2009)$ and their spreadsheet calculator software was used in this study to approximate the average ambient stream concentrations (picograms per liter) from the total cumulative sampler concentrations (nanograms per SPMD). Alvarez and others (2004) found that the uptake of chemicals into the SPMD can be assumed to be linear for up to 1 month for non-polar compounds $\left(\mathrm{K}_{\mathrm{OW}} \geq 5.0\right)$, and given that the devices in the current study were deployed for a 4-week period, the assumption of linear uptake was used here. POCIS samplers target more hydrophilic compounds, so the conversion for ambient concentrations from POCIS samplers was not made. Ambient concentrations are assumed not to be depleted as the samplers were deployed in flowing water. Alvarez and others (2007) developed regression models to estimate the sampling rates and SPMD-water partition coefficients $\left(\mathrm{K}_{\mathrm{SW}}\right)$ for PCBs, PAHs, and non-polar pesticides, and used these relations in their spreadsheet calculator.

\section{Analytical Methods}

A USGS report (Zaugg and others, 2006) describes the analytical methods used by the NQWL for the analysis of organic wastewater from filtered water. Water samples are filtered at the lab and then are extracted by vacuum through disposable solid-phase cartridges that contain polystyrene-divinylbenzene resin. Cartridges are dried with nitrogen gas, and then sorbed compounds are re-eluted with dichloromethane-diethyl ether (4:1) and determined by capillary-column GC/MS. Recoveries of the target chemicals in reagent-water samples fortified at $4 \mu \mathrm{g} / \mathrm{L}$ (micrograms per liter) averaged 74 percent \pm 7 percent relative standard deviation for all method compounds (Zaugg and others, 2006).

Analytical methods used by the NWQL for the analysis of organic wastewater from whole water are described in Zaugg, Smith, and Schroeder (2006). Wastewater compounds in whole-water samples are extracted using continuous liquid-liquid extractors and methylene chloride solvent, and then determined by capillary-column GC/MS. Recoveries in reagent-water samples fortified at $0.5 \mu \mathrm{g} / \mathrm{L}$ averaged 72 percent \pm 8 percent relative standard deviation. The concentrations of 21 compounds were always reported as estimated because method recovery was less than 60 percent (Zaugg, Smith, and Schroeder, 2006).

Stormwater samples and two POCIS samples were analyzed for concentrations of antibiotics and some pharmaceuticals by the USGS OGRL. The analytical method was modified from a liquid chromatography/tandem mass spectrometry (LC/MS/MS) version of the on-line solid-phase extraction (OLSPE) LC/MS method in Meyer and others (2007). Individual antibiotic compounds were analyzed using multiple reaction monitoring (MRM). The method reporting levels (MRLs) ranged from 0.005 to $0.01 \mu \mathrm{g} / \mathrm{L}$ for all analytes except ibuprofen and sulfadiazine, which were $0.1 \mu \mathrm{g} / \mathrm{L}$. POCIS and SPMD extracts were analyzed at the NWQL by GC/MS.

\section{Quality Assurance of Data}

One field blank was collected and analyzed during the synoptic sampling of June 2007 for dissolved and total OWCs to measure potential background contamination due to samplecollection methods. The field blank result included a detection of one dissolved compound, DEET, at an estimated concentration of $0.006 \mu \mathrm{g} / \mathrm{L}$. The lowest estimated detection of DEET in any environmental sample was roughly 4 times the concentrations found in the blank, indicating only a minor interference caused by either the analysis or the sampling process. There were no other detections or estimated concentrations for any other analyte in the total OWC field blank.

Duplicate samples for dissolved OWCs were collected at 5 of the 23 sites during the synoptic sampling in June 2007 to determine reproducibility of results. In the duplicate OWC samples, only one compound (Fyrol CEF) from one duplicate pair was detected above the MRL, and that compound was detected in both samples, at concentrations of 0.9 and 1.0 $\mu \mathrm{g} / \mathrm{L}$ (table 2), indicating good reproducibility. There were 37 duplicate pairs that had estimated concentrations below MRLs in both samples for a given compound. There were 11 pairs that had an estimated concentration given for one sample, where the associated sample was listed as a "less than" value; however, all of these results were in agreement ("less than 
0.5 " compared to an estimated concentration of $0.1 \mu \mathrm{g} / \mathrm{L}$ ). One duplicate pair was collected for TOC, and the results were 2.1 and $2.4 \mu \mathrm{g} / \mathrm{L}$, also indicating good reproducibility.

At the five sites, there were 49 pairs of OWCs where there was a detection of a given compound in either one or both of the associated duplicates. Of those 49 detections, all of the comparable results were in agreement either by being within $0.1 \mu \mathrm{g} / \mathrm{L}$ of each other when a detection occurred in both samples, or by the detected concentration being within the range of the detection limit of the associated sample (an estimated concentration of $0.05 \mu \mathrm{g} / \mathrm{L}$ compared to a "less than" $0.2 \mu \mathrm{g} / \mathrm{L}$ ).

Duplicate samples for total OWCs were collected at two of the seven sites during the synoptic sampling in June 2007 for OWCs. In the first duplicate pair, nine compounds had estimated detections for both samples, and two compounds had an estimated value for one sample, but not the other. In the second pair, six compounds had estimated detections in both samples, and three had an estimated value for one sample, but not the other. In both duplicate sets, where there were estimated values for one sample and not the other, all pairs except for one were in agreement $(<1.6$ compared to an estimated value of $0.4 \mu \mathrm{g} / \mathrm{L}$ for 5 -methyl-1H-benzotriazole). The exception had an estimated concentration of $1.2 \mu \mathrm{g} / \mathrm{L}$ compared to a "less than" $0.8 \mu \mathrm{g} / \mathrm{L}$. Because no compound had detections above the MRL in either of the duplicate samples for wholewater samples, no comparison could be made to determine relative percent differences.

Stormwater samples were collected from the Rock Creek at Joyce Road sampling station using a refrigerated automatic sampler, and analyzed for TOC, suspended sediment, and OWCs during storms in June and September 2008. An equipment blank was collected from the Joyce Road automatic sampler prior to the June 2008 stormwater sampling to determine if any crossover contamination for TOC or OWCs was caused by the sample lines between the creek and the sampler. A field blank and a field duplicate were collected during the September 2008 sampling. The only detection in the equipment blank was for TOC at a concentration of 0.25 $\mathrm{mg} / \mathrm{L}$ (milligrams per liter), at roughly one-sixth of the lowest concentration in any of the environmental samples. Two OWCs were detected in the field blank: DEET (at $0.02 \mu \mathrm{g} / \mathrm{L}$ ), and tris(2-butoxyethyl)phosphate was detected at an estimated concentration of $0.24 \mu \mathrm{g} / \mathrm{L}$. The low concentration of DEET found in the blank was not enough to qualify the field concentrations; however, the concentration of tris(2-butoxyethyl) phosphate detected in the blank at a concentration of at least half the concentrations in the field samples brings detected concentrations for that compound into question. (Those concentrations are qualified in data tables later in the report with a "v" indicating blank contamination.)

There were two sets of storm samples collected with the automatic sampler at Joyce Road-on June 27-28 and September 6, 2008. During the September 6 sampling, one pair of duplicate samples was analyzed for dissolved OWCs, and one pair of duplicate samples was analyzed for both dissolved and total OWCs. For the duplicate samples, there were 58 data pairs where there was a value for both samples. Of those 58 data pairs, 38 had the same "less than" values for both analyses. There were 14 pairs where there were detections in both samples. Of those 14 pairs, 11 had both concentrations as estimated values (below the MRL), but each concentration was within $0.03 \mu \mathrm{g} / \mathrm{L}$ of the concentration in the respective duplicate. Three of the 14 pairs had concentrations above the MRL in both samples, and each concentration was within $0.02 \mu \mathrm{g} / \mathrm{L}$ of the concentration in the respective duplicate. There were five duplicate pairs where there was an estimated detection in one sample, but not in the other; however, in each of the five pairs, all were in agreement (for example, an estimated concentration of $0.53 \mu \mathrm{g} / \mathrm{L}$ compared to a "less than" $1.0 \mu \mathrm{g} / \mathrm{L}$ ).

The SPMD samples included two blanks, a field blank, and a "day zero" blank that was prepared at the EST lab, kept in a freezer, and sent to the NWQL for analysis along with the environmental samples. The SPMD field blank was opened at each of the five sites for the same amount of time that each deployed SPMD was open to the air, during both deployment and retrieval of the devices. This procedure is required because the SPMD devices are much more susceptible to absorbing compounds from the air than the POCIS devices. Because the field blank was subjected to 5 times the exposure as any of the deployed devices (same amount of time at five sites), the concentration in the environmental samples was compared to one-fifth of the concentration in the field blank to estimate the amount of atmospheric absorbance from each sampler. Field concentrations that are less than 10 times the concentrations in the blanks are qualified with a " $\mathrm{v}$ " before the concentrations shown in tables and appendixes indicating potential interference. Compounds that were frequently detected in SPMD blanks were diethylphthalate, 1-methylnapthalene, 2-6 dimethylnaphthalene, 2-methylnaphthalene, diethylhexylphthalate, and naphthalene. These compounds also were found in SPMD samples from this study.

An extraction blank was generated during the processing of the POCIS, consisting of the same sorbent material that was used for the field-deployed units. The extraction blank was sealed in a glass ampule, kept in a freezer, and sent to the lab along with the environmental samples. The extraction blank was analyzed using the same method that was used for the field units. Any detection in the extraction blank during the construction or analysis of the material would cause the environmental samples to be qualified as having blank contamination. Eight compounds were detected in the extraction blank. Environmental samples in which these eight compounds were detected, and in which there were substantial concentrations in the extraction blank, are qualified in data tables as having blank contamination.

Surrogate compounds are injected into a sample at the laboratory to determine how much of a known concentration in a sample is detected by the instrument. The concentration is reported as the percent recovered of the original injected compounds. Acceptable percent recoveries for reporting 


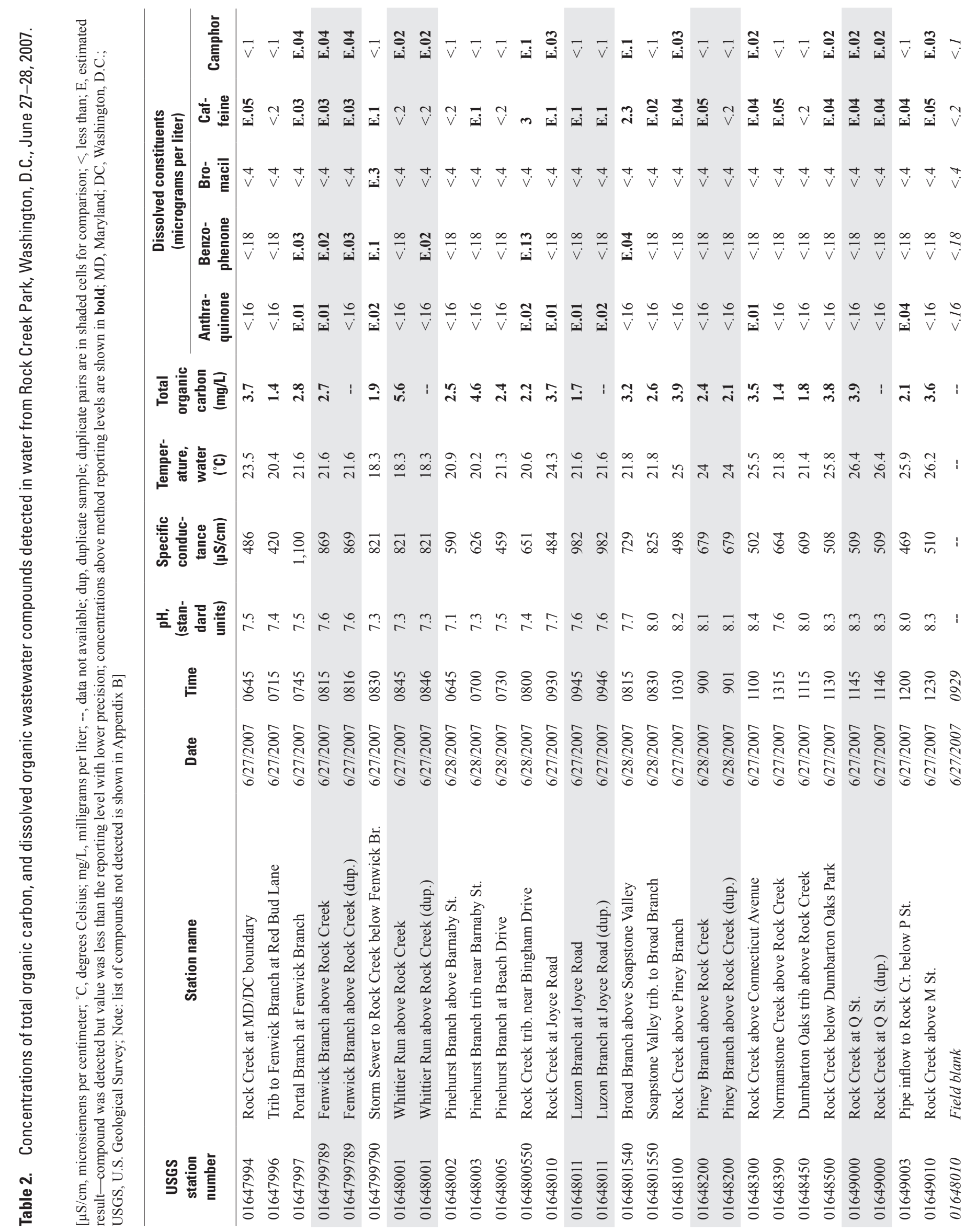




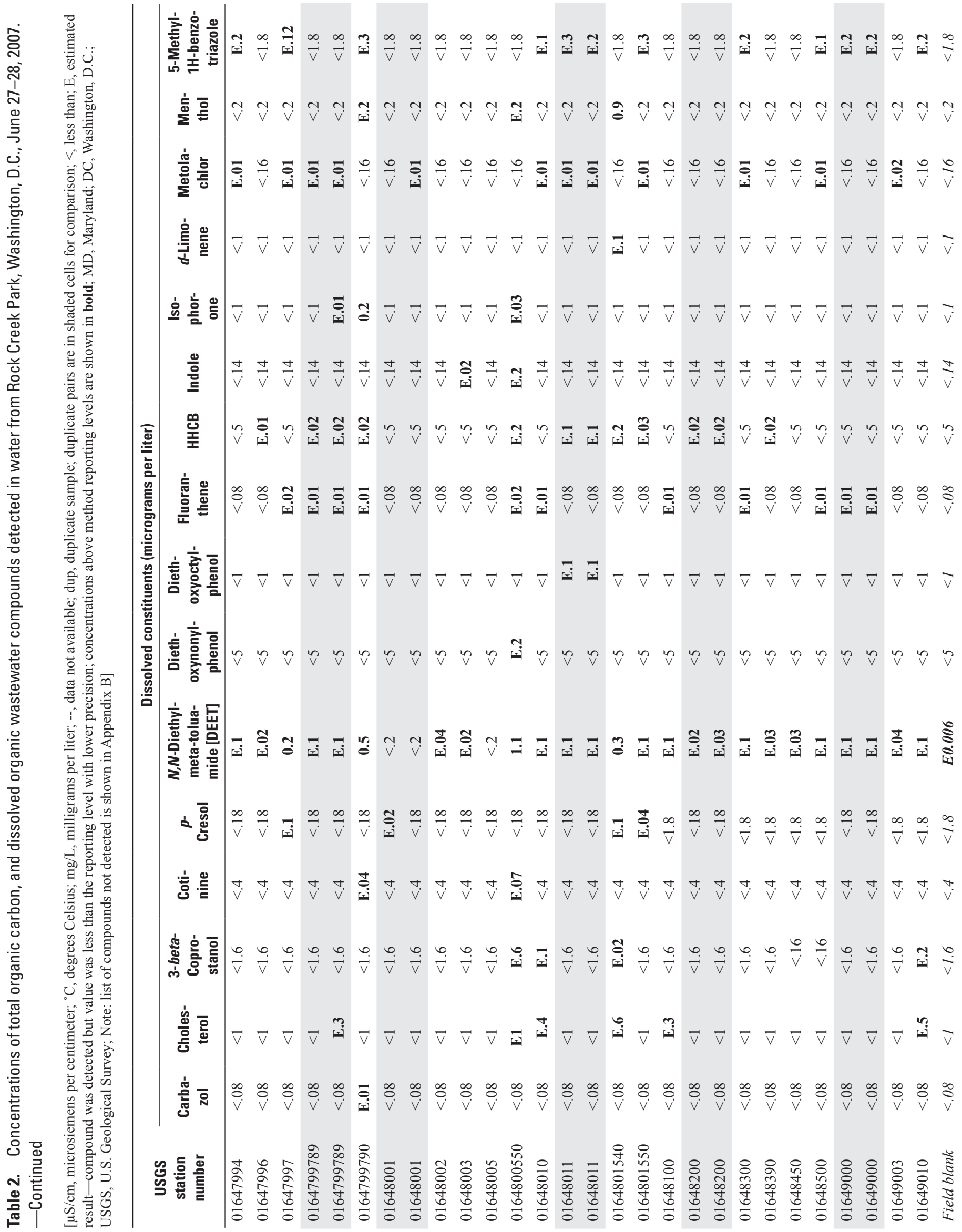




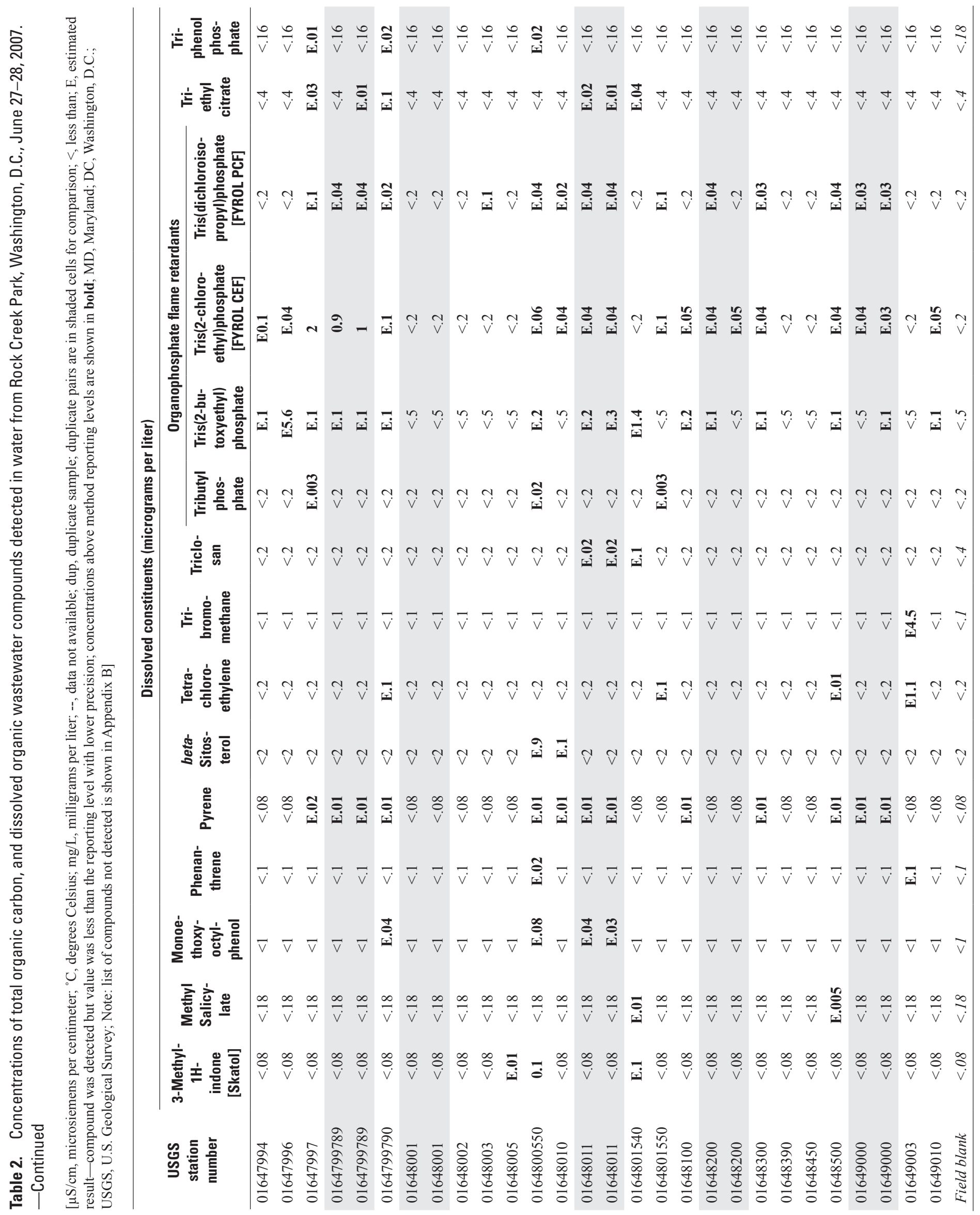


quantified values typically range from about 50 to 125 percent depending on the surrogate, but bisphenol A-d3 had the lowest acceptable recovery at 5 percent. When percent recoveries are out of acceptable ranges, concentrations of compounds that are associated with the specific surrogate compounds are flagged as "R-deleted" in data tables. During this investigation, there were unacceptable ranges of analytical recoveries for dissolved bisphenol A. Therefore, results for bisphenol A and pentachloroethane were deleted from the data tables.

\section{Water-Quality Data}

Results from the analysis of the June 2007 synoptic water-quality and streambed sediment sampling, the stormwater-quality sampling from Rock Creek at Joyce Road, and the passive samplers are presented in the following sections. Data are presented in tables within each section, and in appendixes at the end of the report. A graph showing the long-term average discharge from 1929-2008 and daily mean discharge for water years 2007-08 from the gage on Rock Creek at Sherrill Drive is shown in figure 4 . The time periods for each of the sampling events described in the following sections are also included in figure 4 to show streamflow conditions during each sampling event.

\section{Synoptic Water-Quality Data}

Surface-water samples were collected at the 23 sites (fig. 2) on June 27-28, 2007 during base-flow conditions, and analyzed for dissolved OWCs, dissolved pharmaceuticals, and TOC. Seven of the sites were on the main channel of Rock Creek, and 16 sites were on tributaries. Additional water samples were collected at seven sites and analyzed for total concentrations of OWCs. Bottom sediment samples were collected at the same seven sites as those sampled for total concentrations, and analyzed for concentrations of OWCs in the sediment (table 1). Samples were sent to the NWQL for analysis.

\section{Dissolved Organic Wastewater Compounds}

Water samples were filtered and analyzed at the lab for concentrations of 66 different dissolved OWCs. Thirty compounds were detected at least at one site; concentrations of those 30 compounds are listed in table 2. A list of all 66 compounds that were analyzed, and which compounds were detected or not detected, is presented in Appendix B. Six dissolved OWCs had concentrations above the MRL and those results are summarized in table 3 . There were no detections or estimated concentrations in the field blank.
The MRL is defined by the NWQL as the smallest measured concentration of a substance that can be reliably quantified by use of a given analytical method. It is the "less than" value reported when an analyte is not detected. The "E" remark code is used to signify that a measured concentration is estimated by the NWQL. A wide variety of conditions can justify invoking the "E" remark (Childress and others, 1999). In this report, data values qualified with the "E" remark are typically below the MRL, but above the long-term method detection limit (LT-MDL), and are coded as estimated because of lower precision in these values. All MRLs ranged from 0.08 to $1.4 \mu \mathrm{g} / \mathrm{L}$, with the exception of one compound (diethoxynonylphenol) that had a MRL of $5 \mu \mathrm{g} / \mathrm{L}$ (table 2).

The three compounds detected at more than half the sites were caffeine, DEET, and Fyrol CEF. Caffeine is a natural stimulant and diuretic used throughout the world. DEET is a common insect repellant. Fyrol CEF [tris(2-chloroethyl) phosphate] is used as a flame retardant in plastics, and in the construction of both flexible and rigid foams.

The number of detections found at each site ranged from 0 to 24 compounds (table 2) out of 66 compounds that were analyzed (Appendix B). The five sites (fig. 2) with the greatest number of detections along with the number of detections at each site were:

\begin{tabular}{|c|c|c|}
\hline $\begin{array}{c}\text { U.S. } \\
\text { Geological } \\
\text { Survey } \\
\text { station } \\
\text { number }\end{array}$ & $\begin{array}{l}\text { Site name/ } \\
\text { location }\end{array}$ & $\begin{array}{c}\text { Number of } \\
\text { detections of } \\
\text { organic wastewater } \\
\text { compounds }\end{array}$ \\
\hline 0164800550 & $\begin{array}{l}\text { Rock Creek tributary near } \\
\text { Bingham Drive }\end{array}$ & 24 \\
\hline 0164799790 & $\begin{array}{l}\text { Storm sewer to Rock Creek } \\
\text { below Fenwick Branch }\end{array}$ & 21 \\
\hline 01647997 & $\begin{array}{l}\text { Portal Branch at Fenwick } \\
\text { Branch }\end{array}$ & 16 \\
\hline 0164801540 & $\begin{array}{l}\text { Broad Branch above } \\
\text { Soapstone Valley }\end{array}$ & 15 \\
\hline 0164799789 & $\begin{array}{l}\text { Fenwick Branch above } \\
\text { Rock Creek }\end{array}$ & 14 \\
\hline
\end{tabular}

These five sites were selected for the placement of passive POCIS and SPMD samplers to allow time-weighted measurements in July 2008, a month that included several storms. Of the sites on the main stem of Rock Creek within Rock Creek Park, the number of detections of dissolved OWCs in the synoptic survey was highest at the Joyce Road site (13 detections), where the USGS operates a gaging station that includes a refrigerated automatic stream sampler. Downstream from Joyce Road, stations on the main stem Rock Creek had from 8 to 12 detections of OWCs. 


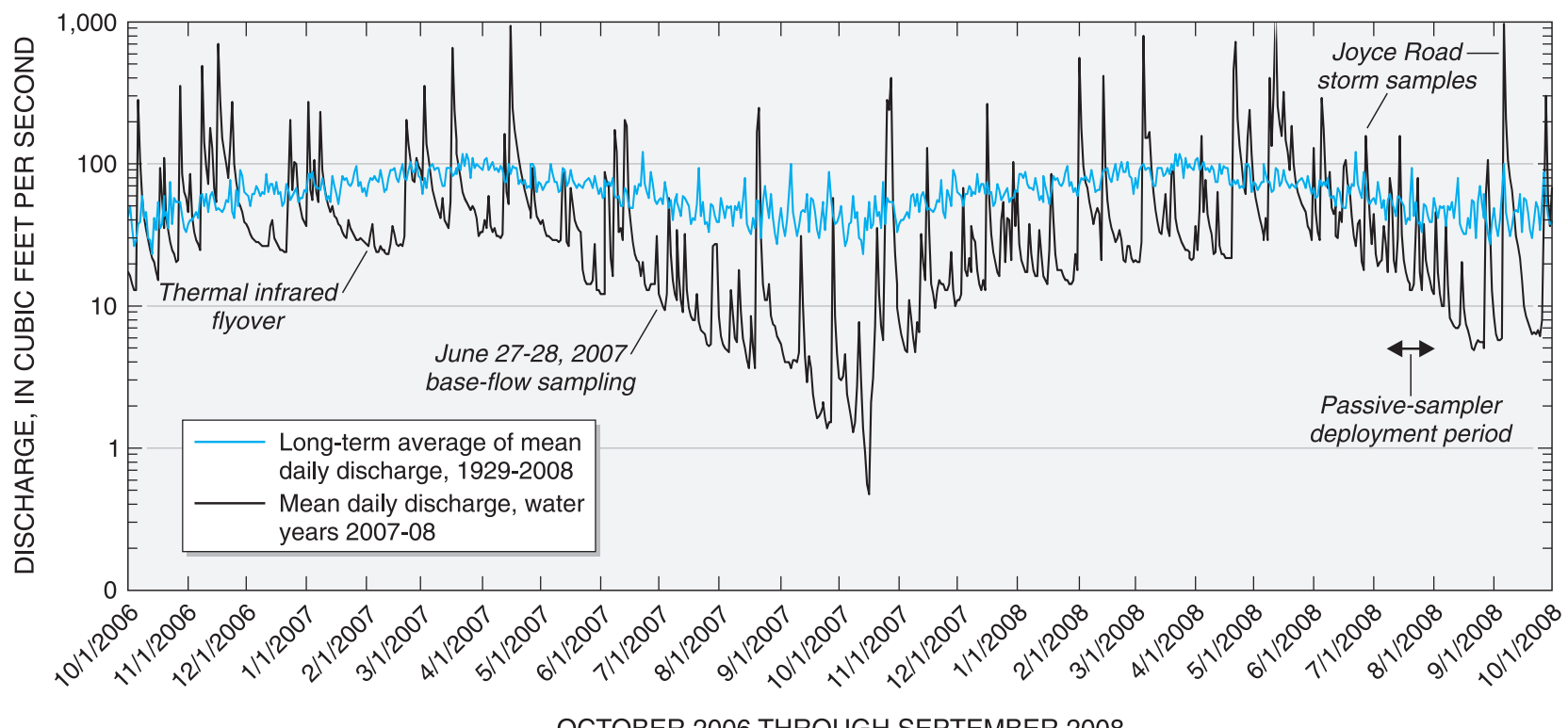

Figure 4. Long-term average discharge and daily mean discharge from October 2006 through September 2008 at Rock Creek at Sherrill Drive, Rock Creek Park, Washington, D.C.

Table 3. Summary of dissolved organic wastewater compounds detected at concentrations above method reporting levels in samples from Rock Creek Park, June 27-28, 2007.

$[\mu \mathrm{g} / \mathrm{L}$, micrograms per liter; see table 2 for details and results by site $]$

\begin{tabular}{|c|c|c|c|c|c|}
\hline Compound name & $\begin{array}{c}\text { Common } \\
\text { compound uses }\end{array}$ & $\begin{array}{c}\text { Maximum } \\
\text { concentration } \\
(\mu \mathrm{g} / \mathrm{L})\end{array}$ & $\begin{array}{l}\text { Number of sites } \\
\text { with detections } \\
\text { above the method } \\
\text { reporting level }\end{array}$ & $\begin{array}{l}\text { Number of sites } \\
\text { with detections } \\
\text { below the method } \\
\text { reporting level }\end{array}$ & $\begin{array}{c}\text { Method } \\
\text { reporting level } \\
(\mu \mathrm{g} / \mathrm{L})\end{array}$ \\
\hline $\begin{array}{l}N, N \text {-Diethyl-meta-toluamide } \\
\quad \text { [DEET] }\end{array}$ & Insect repellant & 1.1 & 3 & 17 & 0.2 \\
\hline Isophorone & Solvent & 0.2 & 1 & 2 & 0.1 \\
\hline 3-Methyl-1H-indone [Skatol] & Fragrance & 0.1 & 1 & 2 & 0.08 \\
\hline
\end{tabular}

\section{Dissolved Pharmaceuticals}

Water samples were collected from each of the 23 sites (fig. 2) for analysis of a suite of nine common pharmaceuticals at the USGS NWQL (table 4). Of those nine compounds, the compounds butalbital and oxycodone were the only compounds detected at estimated concentrations $(0.2 \mu \mathrm{g} / \mathrm{L})$ that were below the MRL of $0.4 \mu \mathrm{g} / \mathrm{L}$. Butalbital is a barbiturate that is often combined with aspirin and acetaminophen by manufacturers to form other medications. Oxycodone is an active ingredient in widely prescribed pain medications. Each of these medications was detected only at the Rock Creek tributary near Bingham Drive (station 0164800550), the sampling station with the greatest number of detections of dissolved OWCs, which is not in a region that is served by a CSS system (fig 3). POCIS and SPMD samplers were placed at this site in July 2008 on the basis of results from dissolved pharmaceuticals and OWCs; these results are described in the Passive-Sampler Data section of this report. 


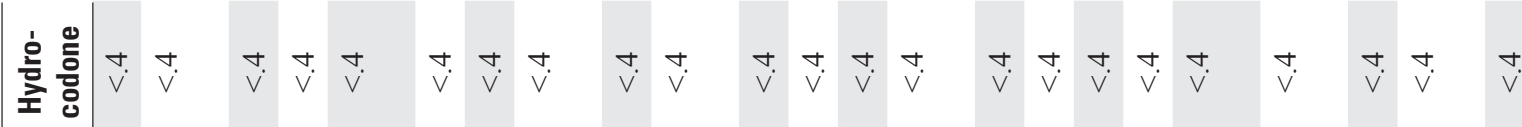

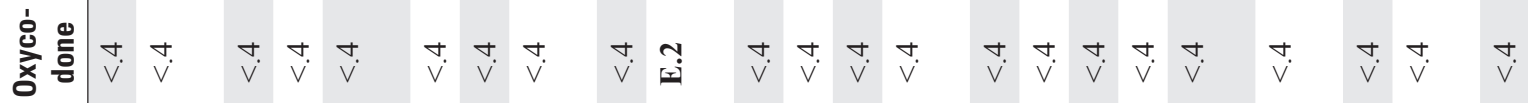
竞

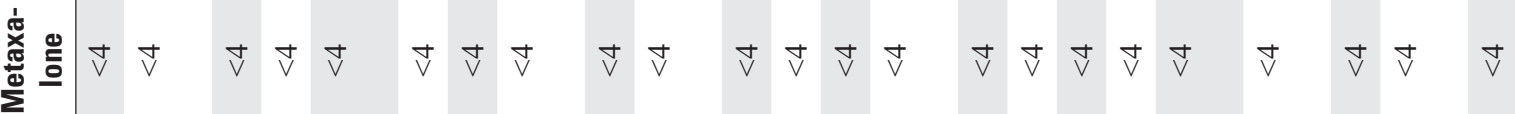

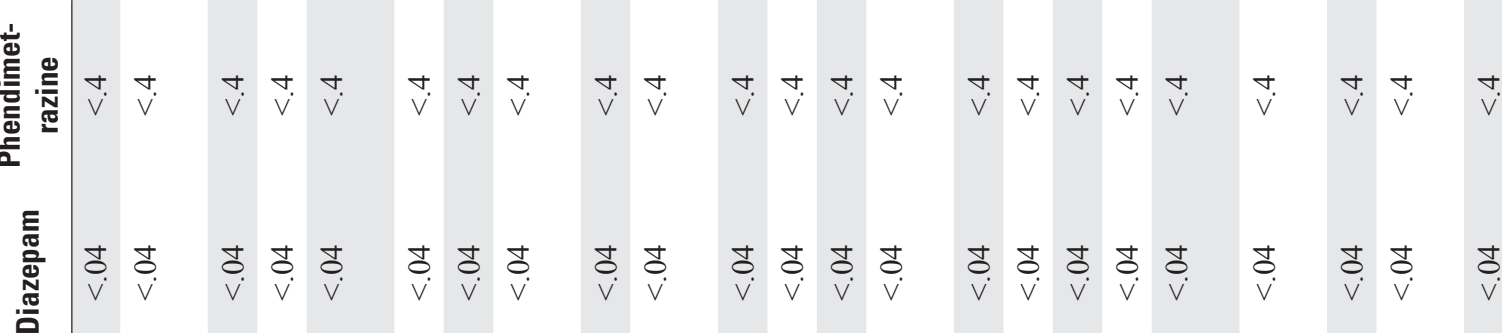

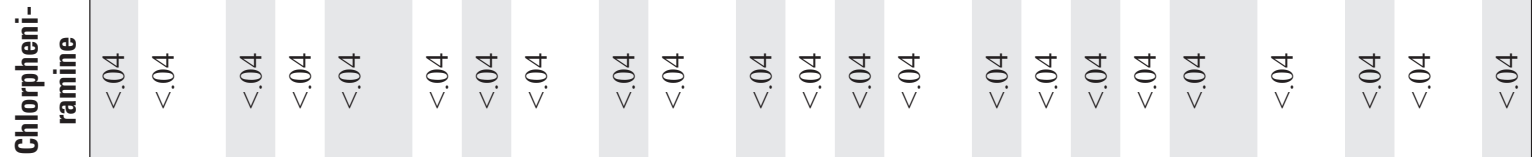

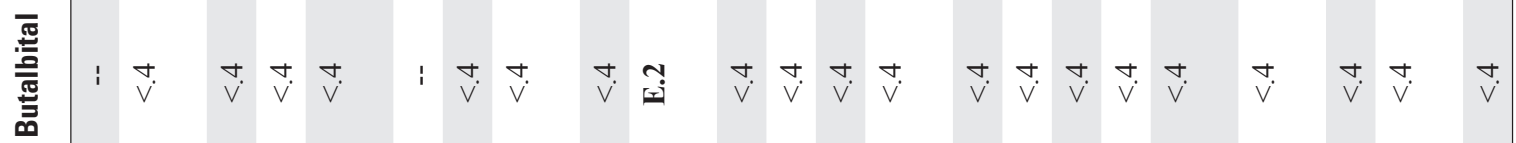

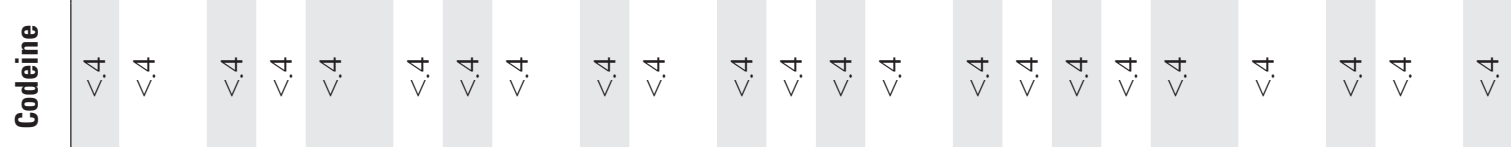

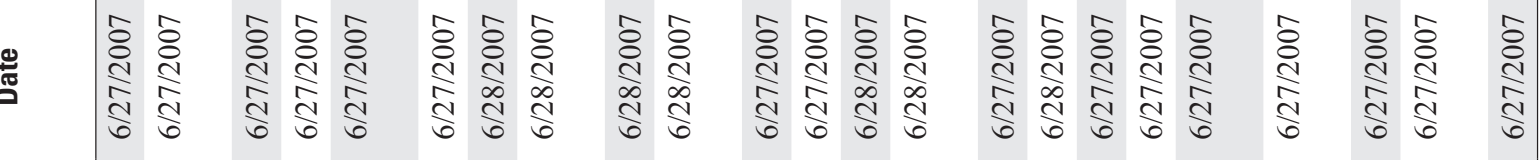

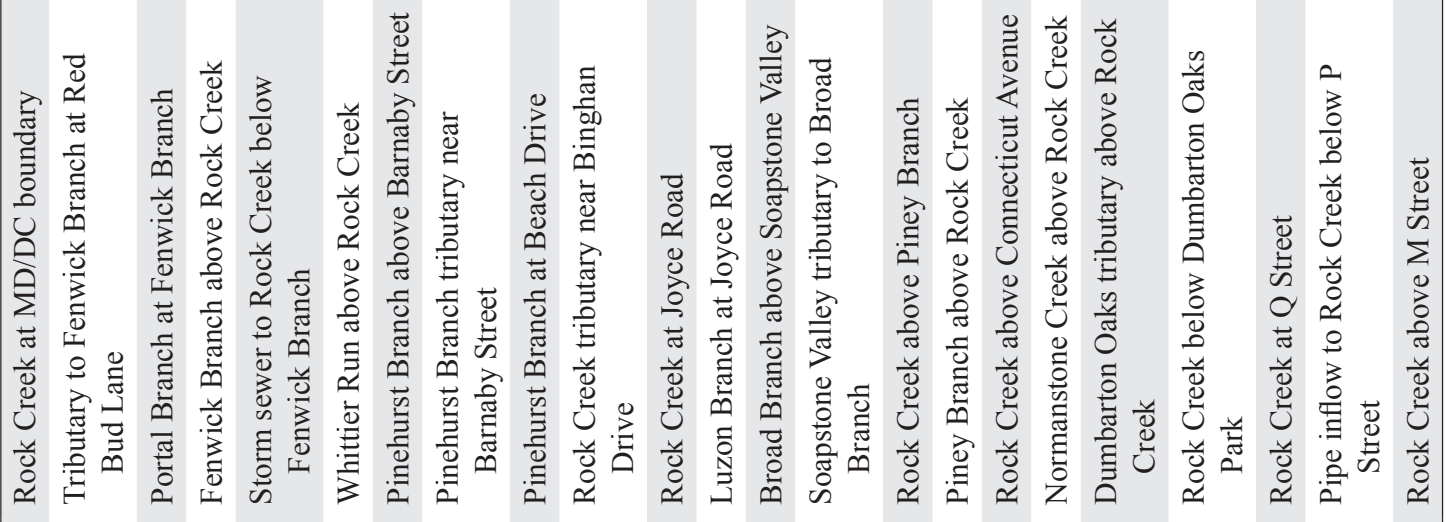




\section{Total Organic Wastewater Compounds}

Whole-water samples to be analyzed for total concentrations of organic wastewater compounds were collected at 7 of the 23 sites that were sampled for dissolved OWCs. Three of the seven sites were on the main stem of Rock Creek, and the other four were on tributaries. Duplicate samples from two of the seven sites were collected and analyzed. One field blank was collected for analysis for total OWCs. Analyses of wholewater samples are more likely to detect OWCs that are carried on fine-grained and colloidal material than analyses of filteredwater samples, but are limited by generally higher reporting levels than for dissolved concentrations.

Analyses were performed for the presence of 69 compounds, and 20 of these compounds were detected at one or more sites. A summary of the number of detections by analyte is shown in table 5. All results for the 20 detected compounds by station are shown in table 6 . A list of all compounds that were analyzed for, including compounds that were not detected, is shown in Appendix C.

Of the 20 detected compounds, the concentration of only one was above the MRL (diethylphthalate, $0.6 \mu \mathrm{g} / \mathrm{L}$, at the upstream site at the MD/DC boundary). Diethylphthalate is a plasticizer and industrial solvent and is used in many applications including cosmetics and personal-care products, food packaging, and other plastics. Results for the other 19 OWCs were all estimated values near or below the MRL and are qualified. MRLs ranged from 0.2 to $3.2 \mu \mathrm{g} / \mathrm{L}$, with 43 of the 69 compounds having a MRL of $0.2 \mu \mathrm{g} / \mathrm{L}$. Compounds detected in these samples were from a wide range of sources including plasticizers, herbicides, flame retardants, wood preservatives, disinfectants, anti-corrosives, fragrances, and fecal indicators.

Fifteen of the 20 compounds detected in the wholewater analyses also were detected in the unfiltered samples. Concentrations of DEET, organophosphate flame retardants, and $\mathrm{HHCB}$, a common fragrance in cosmetics and detergents, were similar between the dissolved and whole-water analyses, indicating that these were primarily in the dissolved phase. Five compounds were detected in the whole-water samples but not detected in the filtered samples. These compounds were atrazine and 1,4-dichlorobenzene (pesticides), 3,4-dichlorophenyl isocyanate and diethylphthalate (plasticizers), and pentachlorophenol (wood preservative). On the main stem of Rock Creek, the number of detections of wastewater compounds in whole-water samples actually decreased slightly with distance downstream from the upstream site at the MD/ DC boundary.

\section{Synoptic Bed-Sediment Data}

Samples of creek-bottom sediments were collected at seven sites in the study area on June 27-28, 2007 (fig. 2), and analyzed for concentrations of OWCs. Some organic compounds are less soluble than others, and may reside in the particulate phase in aquatic environments; therefore, bed sediments (particularly fine-grained sediments) may act as reservoirs for these compounds. Creek-bottom samples were collected with the intention of gathering primarily fine-grained sediments; however, because of the relatively high-energy hydrologic environment at the seven stations, there was very little fine-grained material available for collection. Samples were collected from small pools within about 50 yards upstream or downstream from the water-quality sampling sites in order to collect enough fine-grained bed sediment suitable for analysis.

Bed sediments were analyzed for 56 OWCs (Appendix D), of which 22 compounds were detected at at least one site (table 7). The following OWCs were detected in the sediment at each of the seven sites:

\begin{tabular}{|c|c|c|}
\hline Compound & Category & Uses \\
\hline Anthracene & $\mathrm{PAH}^{1}$ & dyes, insecticides, wood preservative \\
\hline Anthraquinone & PAH & dyes, bird repellant \\
\hline Benzo[a]pyrene & РAH & $\begin{array}{l}\text { formed from incomplete combustion } \\
\text { of organic materials }\end{array}$ \\
\hline Carbazole & $\mathrm{OWC}^{2}$ & insecticide, dyes, lubricants \\
\hline Fluoranthene & PAH & asphalt and coal tar \\
\hline Indole & OWC & $\begin{array}{l}\text { used in perfumes and fragrances, } \\
\text { and found in coal tar }\end{array}$ \\
\hline Phenanthrene & PAH & $\begin{array}{l}\text { component of tar, diesel fuel, dyes, } \\
\text { drugs, explosives }\end{array}$ \\
\hline Pyrene & PAH & asphalt and coal tar \\
\hline
\end{tabular}

Fluoranthene, phenanthrene, and pyrene were three of the four compounds detected at the highest overall concentrations in bed sediment at each of the seven sites. This suite of compounds was found at all seven sites, and all are PAHs that are commonly found in asphalts, indicating that asphalt may be a likely source given the urban nature of much of the Rock Creek Basin (Van Metre and Mahler, 2005). The fourth compound was benzo[a]pyrene, a PAH that is a combustion byproduct commonly found in urban environments (Van Metre and Mahler, 2005). Two other PAH compounds that were found in sediment at each site, but at generally lower concentrations, were anthracene and carbazole, each of which has a range of sources.

Selected PAHs in bed sediment were sampled by Miller and others (2006) at Peirce Mill and by Anderson and others (2002) at three stations in the Park, one of which was very close (within 100 yards) to one of the seven stations sampled during this study (Rock Creek at Q Street). Four PAH compounds found in the study byAnderson and others (2002) that also were analyzed in this investigation were anthracene, benzo[a]pyrene, fluoranthene, and pyrene. A comparison of concentrations for those four compounds at Rock Creek at 


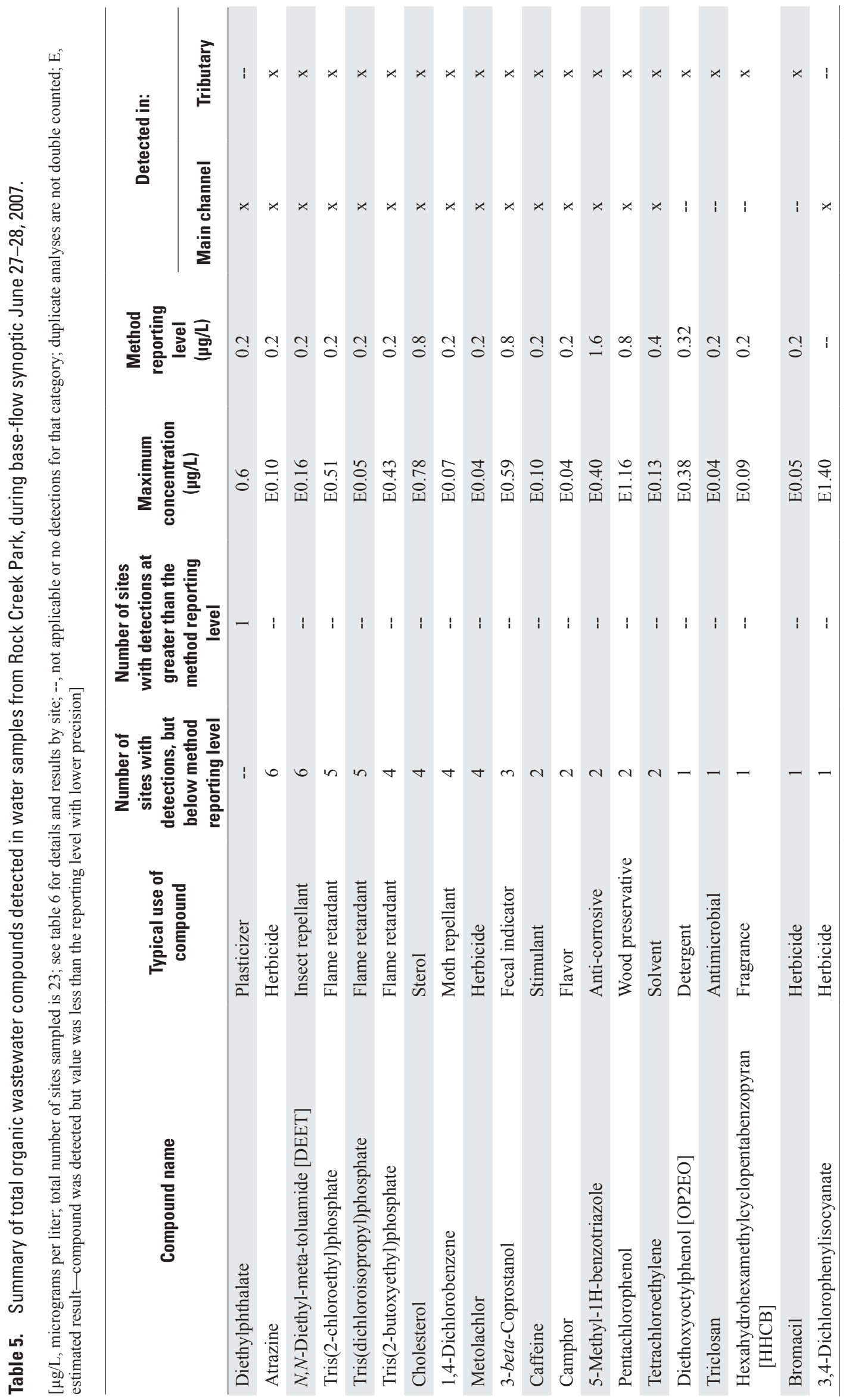




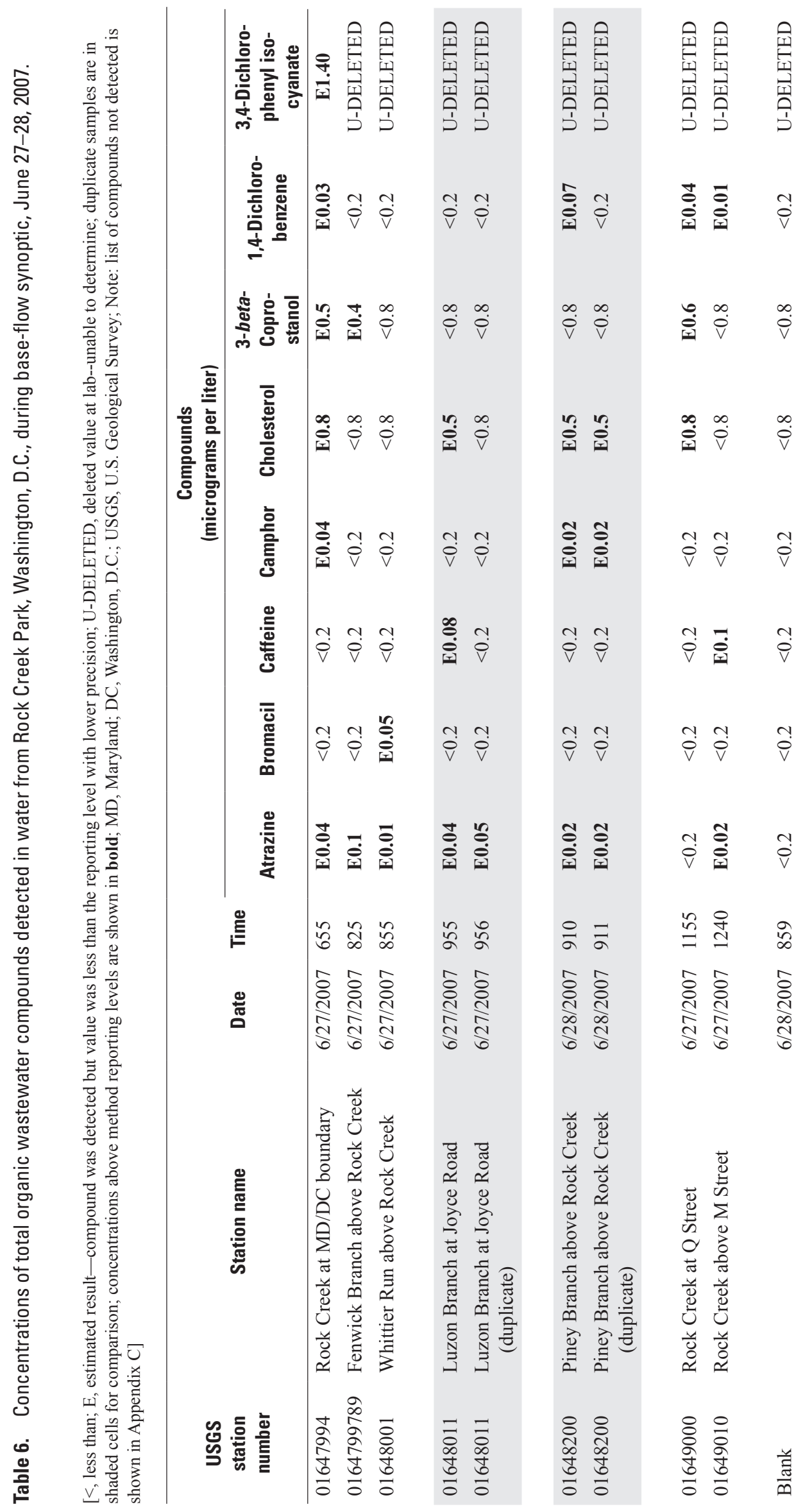




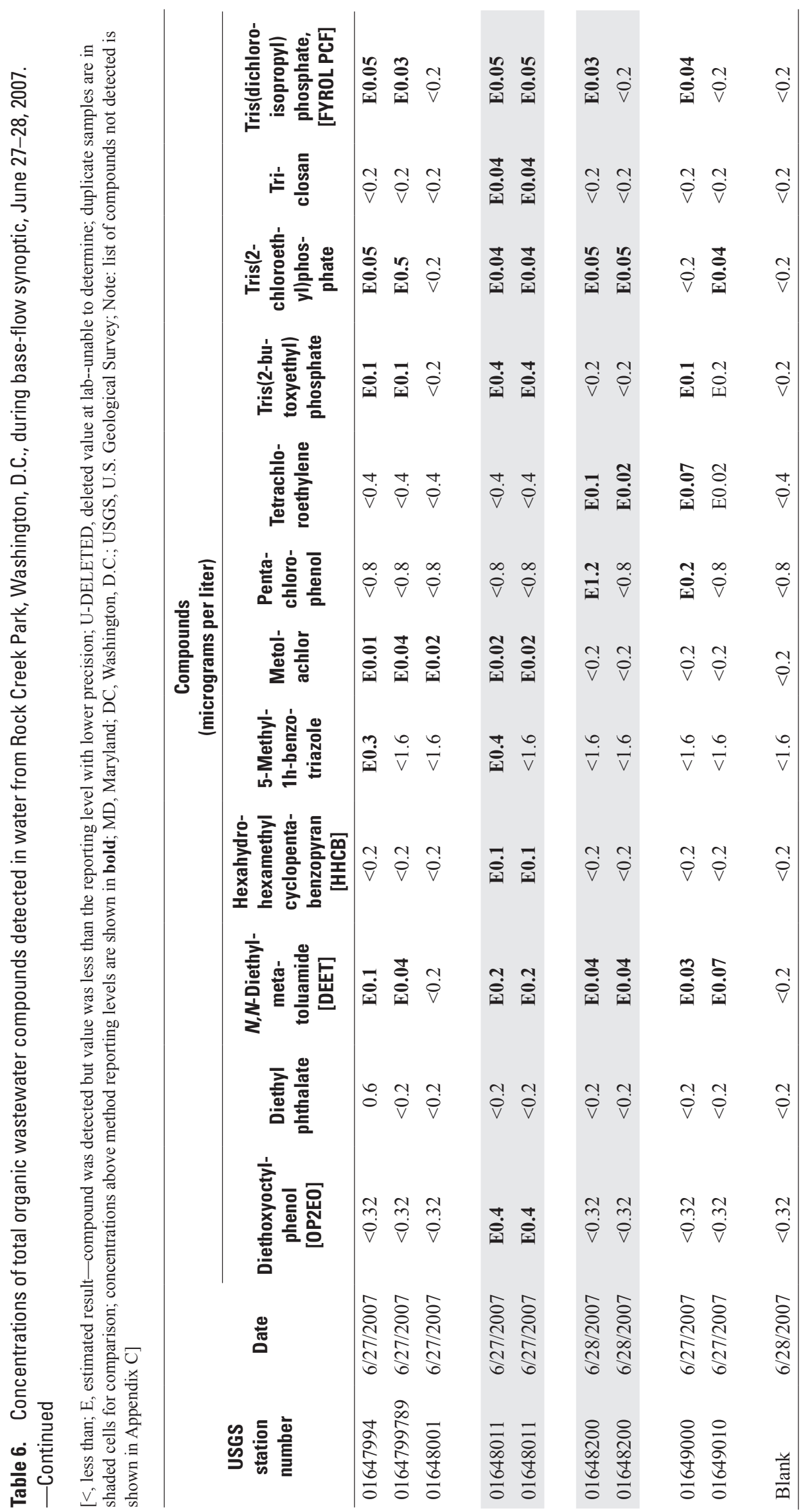




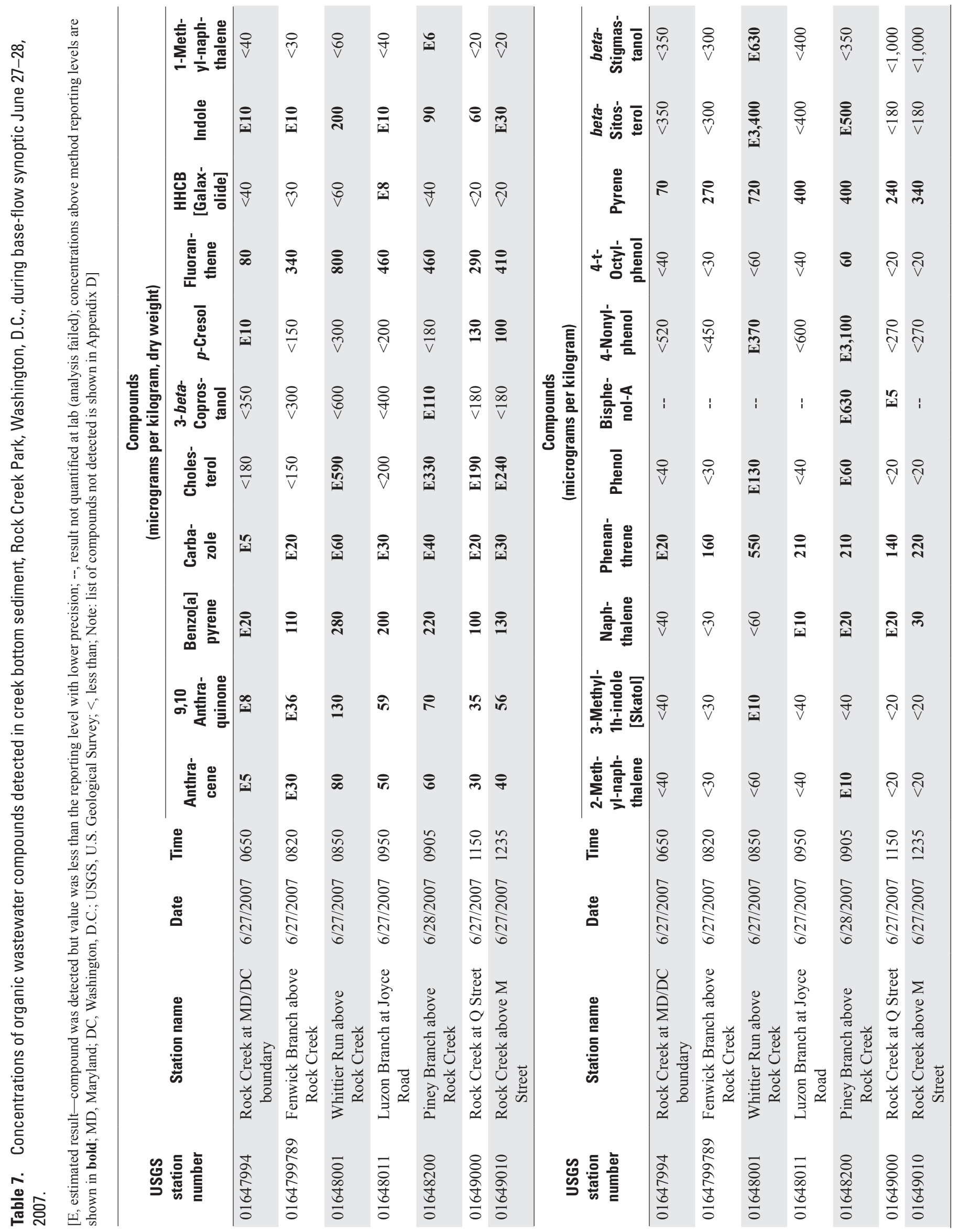


Q Street between the Anderson study and this investigation showed that concentrations of each of the four compounds for this investigation (sampled in June 2007) were all less than one-fifth of the concentrations found in the Anderson study (sampled in August 1999). However, concentrations were not normalized to TOC, so comparisons may not be valid.

\section{Stormwater-Quality Data}

Two series of stormwater samples were collected at the Rock Creek at Joyce Road gaging station (fig. 2) using an automated sampler (American Sigma 900Max) that began sampling when a specified stage threshold value was exceeded. The first set of six samples was collected on June 27-28, 2008, when the discharge at Joyce Road increased from $12 \mathrm{ft}^{3} / \mathrm{s}$ to $736 \mathrm{ft}^{3} / \mathrm{s}$ in a period of 5 hours (fig. 5a). Four of the six samples were analyzed for dissolved OWCs, and three were analyzed for total OWCs. Two of the six were analyzed for both dissolved and total OWCs. All six were analyzed for bacteria and TOC, and five were analyzed for suspended sediment. Results of the analysis for OWC concentrations in the Joyce Road stormwater samples are shown in Appendix E.

The second set of samples was collected on September 6, 2008, when the discharge increased from $8 \mathrm{ft}^{3} / \mathrm{s}$ to $1,970 \mathrm{ft}^{3} / \mathrm{s}$ over 20 hours during tropical storm Hanna (fig. 5b). During the September 2008 sampling, four sets of samples were selected to be analyzed for bacteria, TOC, and OWCs based on the discharge.

Most OWC analyses were performed on filtered water, as the analyses for dissolved OWCs generally had lower detection limits. A comparison was made between the number of detections found in all of the dissolved and total OWC stormwater samples collected. Not counting duplicate or blank analyses, between the two storms, there were eight environmental samples analyzed for concentrations of dissolved OWCs, and four samples analyzed for concentrations of total OWCs, and the distribution of the results is shown below:

\begin{tabular}{lcc}
\hline \multicolumn{1}{c}{ Sample type } & $\begin{array}{c}\text { Total } \\
\text { number of } \\
\text { results with } \\
\text { “E” values" }\end{array}$ & $\begin{array}{c}\text { Total number } \\
\text { of results with } \\
\text { detections } \\
\text { above the MRL }\end{array}$ \\
\hline $\begin{array}{l}\text { From eight filtered (dissolved) } \\
\text { samples }\end{array}$ & 91 & 22 \\
\hline $\begin{array}{l}\text { From four unfiltered (whole-water) } \\
\text { samples }\end{array}$ & 73 & 16 \\
\hline 1 "E” values are estimated concentrations typically below the minimum \\
reporting level (MRL).
\end{tabular}

\footnotetext{
1 "E" values are estimated concentrations typically below the minimum reporting level (MRL).
}

Although the filtered samples had generally lower MRLs, the samples that were analyzed for total concentrations had a greater number of detections, including both estimated concentrations and concentrations above the MRLs. The greater number of detections is likely due to mobilization and suspension of sediments during higher flows. Bed sediments may represent a substantial pool of OWCs that are periodically mobilized by flows with sufficient shear stresses. The majority of detected OWCs were present at estimated concentrations below the MRLs in both filtered and whole-water analyses. Concentrations of OWCs in the stormwater samples and a list of all the OWCs analyzed are shown in Appendix E. A summary of the compounds detected in the stormwater samples and their detection frequencies are shown in table 8.

Of the OWCs that were detected in the storm samples from the Joyce Road station, seven of the dissolved OWCs and seven of the total OWCs that were detected also were detected in each of the seven samples from bottom sediment (table 7), indicating that these compounds are prevalent throughout much of the basin, and may be more indicative of the effects of storm runoff over urban areas than runoff from CSOs or leaky sewer lines. The compounds are listed in table 9.

Two water samples from each of the two storms at the Joyce Road station were analyzed for dissolved antibiotics and pharmaceuticals by the USGS OGRL. Of the 33 pharmaceutical compounds that were analyzed for each of the 4 storm samples, only 1 compound was detected, just above the detection level (table 10). Carbamazepine was detected at $0.006 \mu \mathrm{g} / \mathrm{L}$, just slightly above the detection level of 0.005 $\mu \mathrm{g} / \mathrm{L}$. Carbamazepine is an anticonvulsant drug used to treat epilepsy, bipolar disorder, and ADHD, and it reduces abnormal excitement in the brain. The presence of the compound was confirmed by the analyst after the analysis of that sample as a routine internal lab duplicate. The OGRL also reported that carbamazepine is one of the most widely detected compounds in surface water in the emerging contaminant studies that they have conducted (Julie Dietze, USGS, written commun., March 2009).

Stormwater samples from the Joyce Road site were analyzed for Escherichia coli (E. coli) and total coliform bacteria and the results are presented in Appendix E. These data show high concentration ranges that are typical of other urban sites in the Washington, D.C. metropolitan area [USGS stations Paint Branch (01649190), Northeast Branch Anacostia River (01649500), and Northwest Branch Anacostia River (01651000)] where the USGS currently conducts storm- and base-flow water-quality sampling. E. coli are present in the intestines of humans and animals, and their presence in high concentrations usually indicates the presence of untreated or poorly treated wastewater in the environment. Exposure to E. coli can cause infections or disease in humans. Maximum concentrations occurred during the peak flow of storm events. 


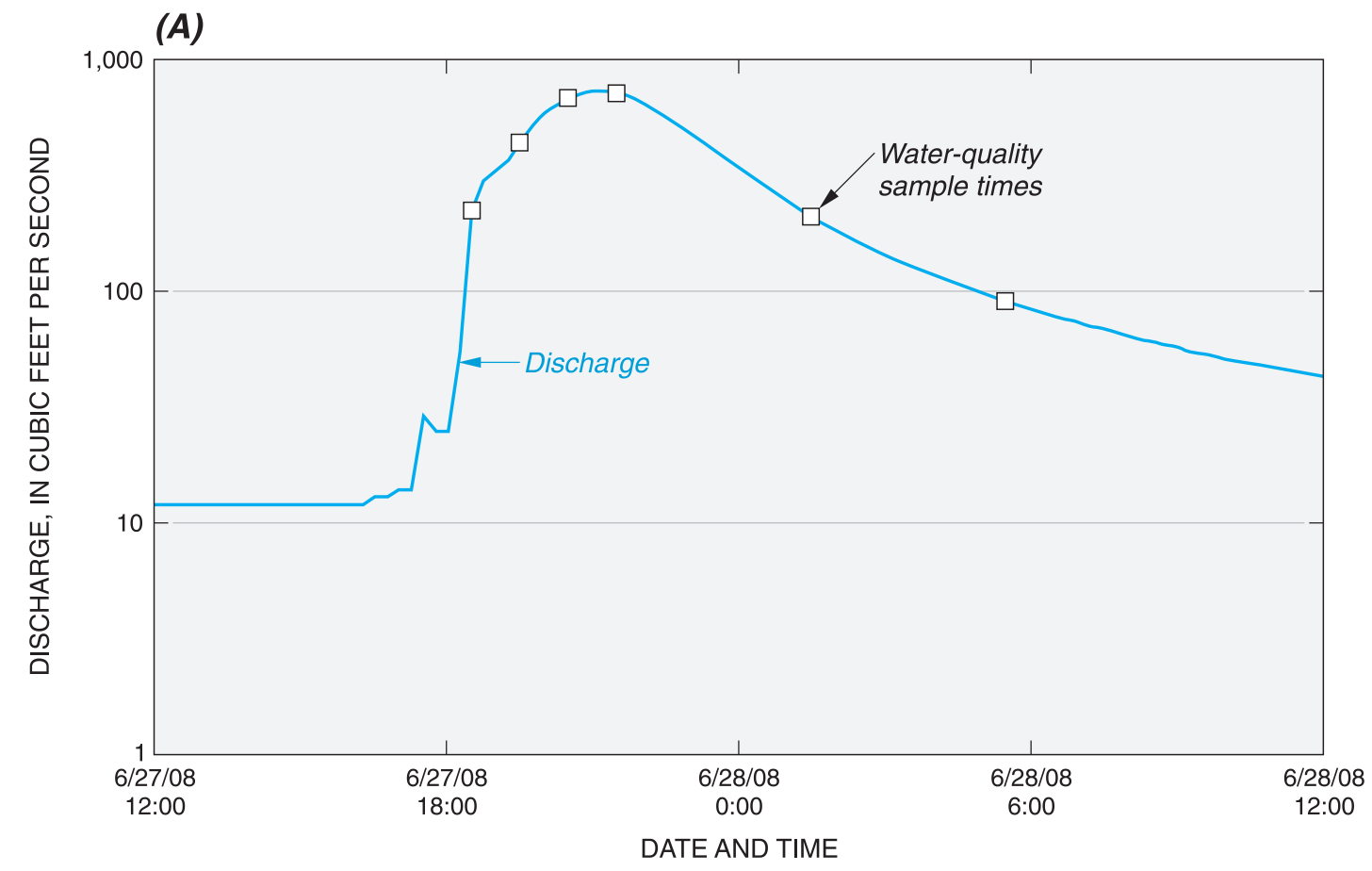

(B)

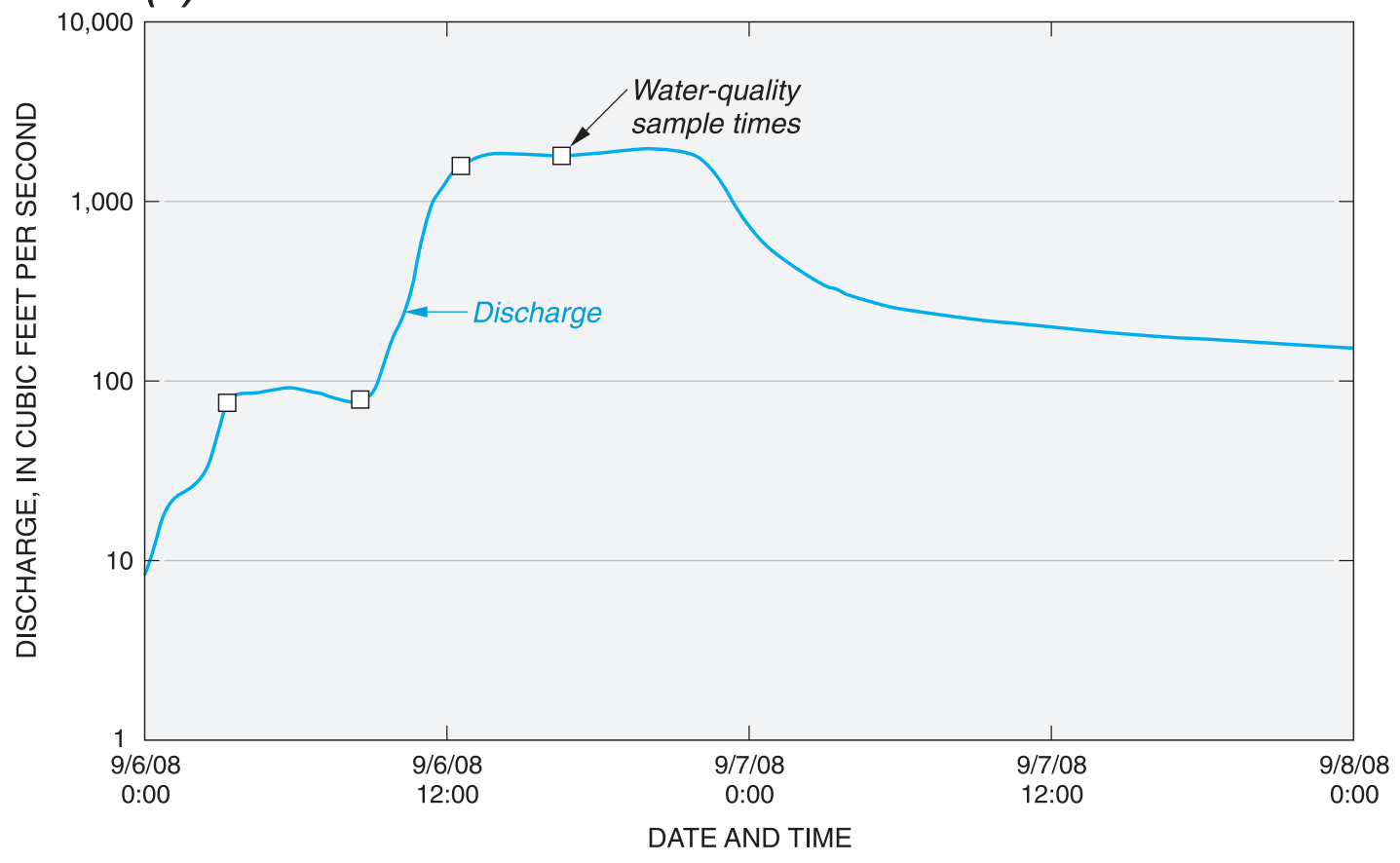

Figure 5. Discharge and sample times from Rock Creek at Joyce Road, Washington, D.C., (A) June 27-28, 2008 and (B) September 6-7, 2008. 
Table 8. Summary of dissolved-and total-organic-wastewater-compound concentrations in stormwater samples collected from Rock Creek at Joyce Road, Washington, D.C. (station number 01648010), June and September 2008.-Col

$[\mu \mathrm{g} / \mathrm{L}$, micrograms per liter; E, estimated result—compound was detected but value was less than the reporting level with lower precision; $\mathrm{v}$, a substantial amount of the compound was detected in an associated blank and may not be a valid detection; duplicate samples were not double counted; Note: compounds are listed in order of rank by total number of detections]

\begin{tabular}{|c|c|c|c|c|c|}
\hline $\begin{array}{l}8 \text { Sets of samples collected for } \\
\text { filtered analysis }\end{array}$ & $\begin{array}{l}\text { Number of } E \\
\text { values }\end{array}$ & $\begin{array}{c}\text { Number of } \\
\text { concentrations } \\
\text { above method } \\
\text { reporting levels }\end{array}$ & $\begin{array}{l}\text { Total number of } \\
\text { detections }\end{array}$ & $\begin{array}{l}\text { Maximum value } \\
(\mu \mathrm{g} / \mathrm{L})\end{array}$ & $\begin{array}{c}\text { Number of } \\
\text { sampled } \\
\text { sediment sites } \\
\text { with detections }\end{array}$ \\
\hline \multicolumn{6}{|c|}{ Results from filtered (dissolved) analyses ${ }^{1}$} \\
\hline$N, N$-Diethyl-meta-toluamide [DEET] & $1^{4}$ & 8 & 8 & 0.56 & 0 \\
\hline 9,10-Anthraquinone & 8 & 0 & 8 & E0.13 & 7 \\
\hline Camphor & 0 & 8 & 8 & E0.069 & 0 \\
\hline Caffeine & 0 & 8 & 8 & 0.53 & 0 \\
\hline Fluoranthene & 8 & 0 & 8 & E0.027 & 7 \\
\hline Isophorone & 8 & 0 & 8 & E0.054 & 0 \\
\hline Pyrene & 8 & 0 & 8 & E0.022 & 7 \\
\hline Tris(2-chloroethyl)phosphate & 6 & 2 & 8 & E0.14 & 0 \\
\hline Tris(dichloroisopropyl)phosphate & 8 & 0 & 8 & E0.15 & 0 \\
\hline Triphenylphosphate & 6 & 0 & 6 & E0.051 & 0 \\
\hline Benzophenone & 4 & 0 & 4 & E0.066 & 0 \\
\hline 3-beta Coprostanol & 3 & 0 & 3 & E0.55 & 7 \\
\hline 5-Methyl-1H-benzotriazole & 3 & 0 & 3 & E0.37 & 0 \\
\hline Carbazole & 3 & 0 & 3 & E0.032 & 7 \\
\hline Cholesterol & 3 & 0 & 3 & E0.92 & 7 \\
\hline Metolachlor & 3 & 0 & 3 & E0.025 & 0 \\
\hline Phenanthrene & 3 & 0 & 3 & E0.024 & 7 \\
\hline Triethylcitrate & 3 & 0 & 3 & E0.030 & 0 \\
\hline Cotinine & 2 & 0 & 2 & E0.11 & 0 \\
\hline Naphthalene & 2 & 0 & 2 & E0.025 & 4 \\
\hline Tribromomethane & 2 & 0 & 2 & E0.013 & 0 \\
\hline 4-tert-Octylphenol monoethoxylate & 1 & 0 & 1 & E0.072 & 0 \\
\hline beta-Stigmastanol & 1 & 0 & 1 & E0.99 & 1 \\
\hline Bisphenol A & 1 & 0 & 1 & E0.12 & 2 \\
\hline $\begin{array}{l}\text { Hexahydrohexamethylcyclopentabenzopyran } \\
\text { [HHCB] }\end{array}$ & 1 & 0 & 1 & E0.013 & 1 \\
\hline Tetrachloroethene & 1 & 0 & 1 & E0.011 & 0 \\
\hline Tris(2-butoxyethyl)phosphate & $9 v$ & 0 & 0 & E0.46 & 0 \\
\hline
\end{tabular}


Table 8. Summary of dissolved- and total-organic-wastewater-compound concentrations in stormwater samples collected from Rock Creek at Joyce Road, Washington, D.C. (station number 01648010), June and September 2008.-Continued

$[\mu \mathrm{g} / \mathrm{L}$, micrograms per liter; E, estimated result—compound was detected but value was less than the reporting level with lower precision; $\mathrm{v}, \mathrm{a}$ substantial amount of the compound was detected in an associated blank and may not be a valid detection; duplicate samples were not double counted; Note: compounds are listed in order of rank by total number of detections]

\begin{tabular}{|c|c|c|c|c|c|}
\hline $\begin{array}{l}4 \text { Sets of samples analyzed for } \\
\text { unfiltered analysis }\end{array}$ & $\begin{array}{l}\text { Number of } E \\
\text { values }\end{array}$ & $\begin{array}{c}\text { Number of } \\
\text { concentrations } \\
\text { above method } \\
\text { reporting levels }\end{array}$ & $\begin{array}{l}\text { Total number of } \\
\text { detections }\end{array}$ & $\begin{array}{l}\text { Maximum value } \\
(\mu \mathrm{g} / \mathrm{L})\end{array}$ & $\begin{array}{c}\text { Number of } \\
\text { sampled } \\
\text { sediment sites } \\
\text { with detections }\end{array}$ \\
\hline \multicolumn{6}{|c|}{ Results from whole-water analyses ${ }^{2}$} \\
\hline Caffeine & 1 & 3 & 4 & 0.56 & 0 \\
\hline 3,4-Dichlorophenyl isocyanate & 4 & 0 & 4 & E2.6 & 0 \\
\hline Anthracene & 4 & 0 & 4 & E0.96 & 7 \\
\hline Anthraquinone & 2 & 2 & 4 & 0.048 & 7 \\
\hline Benzo[a]pyrene & 2 & 2 & 4 & 0.77 & 7 \\
\hline beta-Sitosterol & 4 & 0 & 4 & E4 & 2 \\
\hline Carbazole & 4 & 0 & 4 & E0.13 & 7 \\
\hline Cholesterol & 4 & 0 & 4 & E2.70 & 4 \\
\hline Fluoranthene & 0 & 4 & 4 & 1.42 & 7 \\
\hline Pentachlorophenol & 4 & 0 & 4 & E0.63 & 0 \\
\hline Phenanthrene & 2 & 2 & 4 & 0.49 & 7 \\
\hline Pyrene & 1 & 3 & 4 & 1.17 & 7 \\
\hline Tris(2-butoxyethyl)phosphate & 3 & 1 & 4 & E0.054 & 0 \\
\hline Tris(2-chloroethyl)phosphate & 4 & 0 & 4 & E0.14 & 0 \\
\hline Tris(dichloroisopropyl)phosphate & 4 & 0 & 4 & E0.11 & 0 \\
\hline Atrazine & 3 & 0 & 3 & E0.11 & 0 \\
\hline Camphor & 3 & 0 & 3 & E0.11 & 0 \\
\hline Triphenylphosphate & 3 & 0 & 3 & E0.059 & 0 \\
\hline Triclosan & 2 & 0 & 2 & E0.13 & 0 \\
\hline 2 Methylnaphthalene & 1 & 0 & 1 & E0.016 & 1 \\
\hline 5-Methyl-1H-benzotriazole & 1 & 0 & 1 & E0.36 & 0 \\
\hline Benzophenone & 1 & 0 & 1 & E0.10 & 0 \\
\hline beta-Stigmastanol & 1 & 0 & 1 & E1.06 & 1 \\
\hline bis (2-ethylhexyl)phthalate & 1 & 0 & 1 & E1.18 & 0 \\
\hline Bisphenol A & 1 & 0 & 1 & E0.28 & 2 \\
\hline$N, N$-Diethyl-meta-toluamide [DEET] & 0 & 1 & 1 & 0.63 & 0 \\
\hline Diethylphthalate & 0 & 1 & 1 & 0.34 & 2 \\
\hline para-Cresol & 1 & 0 & 1 & E0.10 & 3 \\
\hline Isophorone & 1 & 0 & 1 & E0.062 & 0 \\
\hline Phenol & 1 & 0 & 1 & E0.085 & 2 \\
\hline
\end{tabular}

${ }^{1}$ See table 2 for concentrations by site and detection levels.

${ }^{2}$ See table 6 for concentrations by site and detection levels.

${ }^{3}$ Seven sites were sampled for concentrations of organic wastewater compounds in bottom sediments in June 2007.

This column compares presence of the compounds in bottom sediments to presence in stormwater samples.

See table 7 for concentrations in bottom sediment samples.

${ }^{4}$ Low concentration detected in blank but does not affect the reported concentration. 
Table 9. Organic wastewater compounds that were detected in stormwater samples at Joyce Road that also were detected at each of the seven sediment-sampling sites.

\begin{tabular}{ll}
\hline $\begin{array}{c}\text { Compounds detected } \\
\text { at Joyce Road in } \\
\text { filtered samples }\end{array}$ & $\begin{array}{c}\text { Compounds detected } \\
\text { at Joyce Road in } \\
\text { unfiltered samples }\end{array}$ \\
\hline 9,10 -Anthraquinone & Anthracene \\
Carbazole & Anthraquinone \\
Cholesterol & Benzo[a]pyrene \\
3-beta Coprostanol & Carbazole \\
Fluoranthene & Fluoranthene \\
Phenanthrene & Phenanthrene \\
Pyrene & Pyrene \\
\hline
\end{tabular}

\section{Passive-Sampler Data}

Combined sets of SPMD and POCIS passive samplers were placed at the five sites that had the highest number of compounds detected during the June 2007 synoptic sampling in Rock Creek Park. The samplers were deployed on July 2, 2008, and retrieved on July 29, 2008.

The POCIS samplers were designed to sample watersoluble (polar/hydrophilic) organic chemicals from aqueous environments whereas the SPMD samplers were designed to sample lipid- or fat-soluble (nonpolar/hydrophobic) semivolatile organic chemicals from water and air. For most chemicals over a 4-week deployment period, the SPMD and POCIS act as integrative samplers, allowing for the detection of very low levels of compounds that might be in the water. Results from the laboratories are expressed in nanograms per ampule of extracted material and are used primarily as screening tools to determine the presence of OWCs and their relative concentrations. Results for SPMD (table 11) have been converted to estimated ambient concentrations in units of pictograms per liter for most compounds based on modeling developed by Alaverez and others (2009). The raw concentrations in units of nanograms per ampule are in Appendixes F and G. The model was not applicable to POCIS samplers so results have not been converted to estimated ambient concentrations.

\section{Semipermeable Membrane Devices (SPMD)}

Samples from the SPMD were analyzed for suites of OWCs and PAHs (Appendix F) and pesticides

(Appendix G). Estimated ambient concentrations are in table 11 and raw concentrations for the samplers are in the appendixes. Of the OWCs and PAHs detected in the SPMD, anthracene, anthraquinone, benzo[a]pyrene, carbazole, fluoranthene, phenanthrene, and pyrene also were found in the stormwater samples at Joyce Road and in each of the creek-bottomsediment samples (table 9), indicating widespread distribution in the Park. Two indicators of wastewater, acetophenone and total para-nonylphenol, were detected in the SPMD

(Appendix F), but were not detected in the sediment or other water samples. Acetophenone (used as a fragrance in soaps and detergents) was detected at each of the five passive-sampler sites. Para-nonylphenol is a detergent metabolite that was only found in the storm-sewer outfall below Fenwick Branch.

Pesticides detected in the SPMD were dieldrin, benfluralin, dacthal, ethion, pendimethalin, and trifluralin (Appendix G), with concentrations of dieldrin roughly 2 to 3 orders of magnitude higher than concentrations of other pesticides. The highest concentration of dieldrin was at the stormsewer-outfall site below Fenwick Branch; however, there was no lab result for dieldrin at the tributary near Bingham Drive for comparison.

A model was used to estimate concentrations in the water based on the concentrations in the extract in the ampules and the partitioning coefficient for each detected compound. The model was developed by USGS CERC and uses a spreadsheet called the SPMD Calculator, version 5 (updated 11/18/2007), based on calculations developed by Huckins and others (2006), and described by Alvarez and others (2009). Not all concentrations can be estimated by use of the model, as it is not valid for compounds with very high or very low partitioning coefficients; however, this is generally not an issue as these compounds are not readily sampled by the SPMD. Estimated average water concentrations in picograms per liter are presented in table 11 .

\section{Polar Organic Chemical Integrative Samplers (POCIS)}

The EST laboratory in St. Joseph, Missouri, extracted the compounds from the sorbent materials into ampules and shipped the ampules to the NWQL for analysis of pesticides and OWCs. Two of the five sets of samples were split, and a portion of the split was sent to the USGS OGRL in Lawrence, Kansas, for analysis for antibiotics. The results from the NWQL analyses are shown in table 12 . The results from the OGRL are shown in table 13.

Twenty-two different pesticides were detected at at least one of the five POCIS sites between two different laboratory schedules (table 12), with the greatest number of pesticides detected at Broad Branch above Soapstone Valley (19 pesticides between the two lab schedules). More than half of the pesticides detected at that site had higher concentrations than those at the other four sites (table 12). The site with the next greatest number of detections was Fenwick Branch above Rock Creek (17 pesticides). Of the 22 pesticides detected, 3 also were detected in the SPMD samplers (dacthal, dieldrin, and trifluralin-Appendix G); however, these three pesticides were detected at more sites in the SPMD samples than in the POCIS samples. Three pesticides (benfluralin, ethion, and pendimethalin) were detected in SPMD samples at one or two of the five sites, but were not detected in the POCIS samples. 


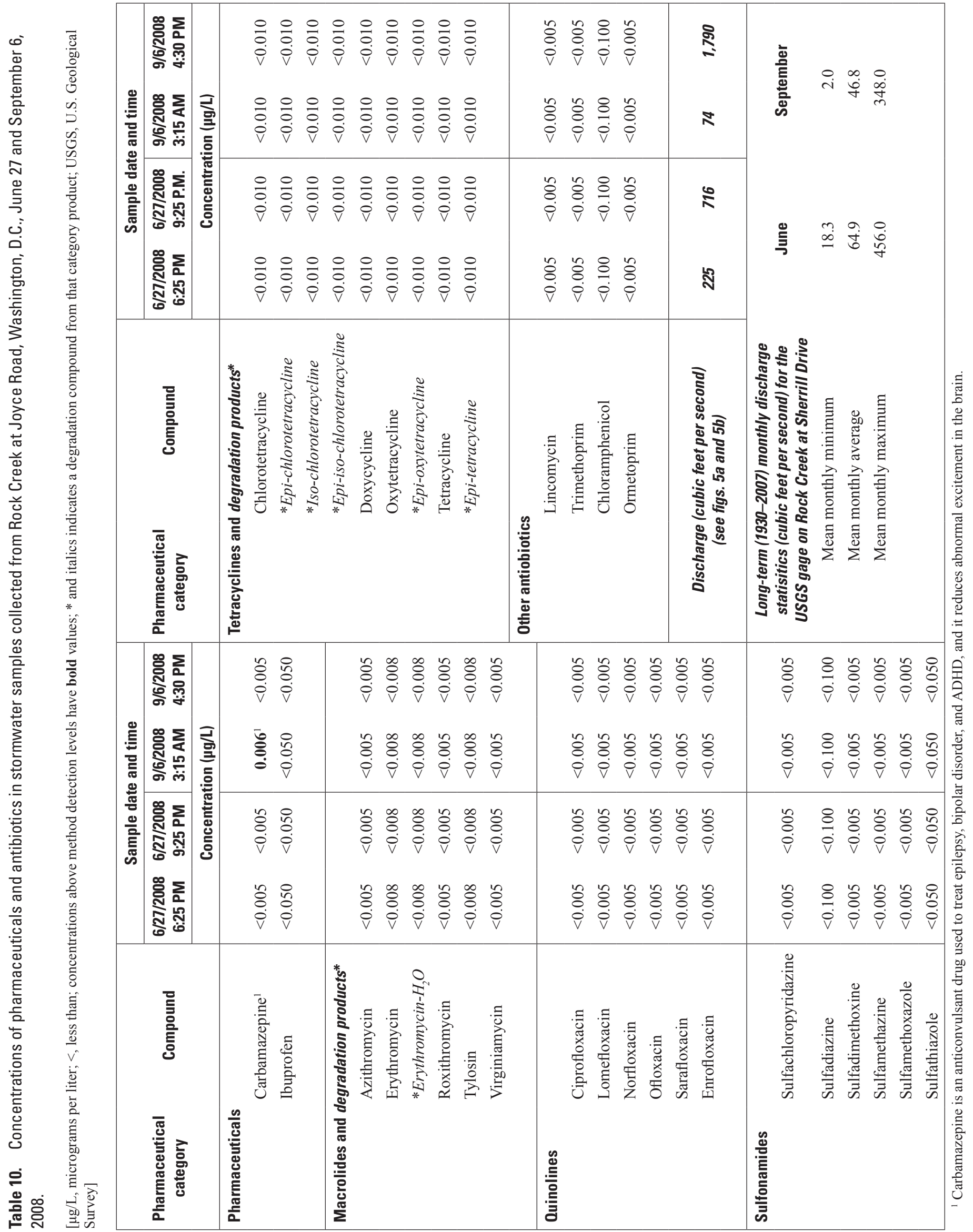


Table 11. Estimated average water concentrations from the Semipermeable Membrane Devices (SPMD) deployed in Rock Creek Park, Washington, D.C., July 2 through 29, 2008.

[pg/L, picograms per liter; PAH, polycyclic aromatic hydrocarbon; an 'E' before a value indicates an estimated concentration near the detection limit for that compound; a " $\mathrm{v}$ " in place of a concentration indicates that the value is questionable because of lab or field contamination; a " $\mathrm{v}$ " in front of a concentration indicates that as much as one third of the concentration may be due to blank contamination; U-DELETED indicates failure of analysis at the lab; results from U.S. Geological Survey National Water Quality Laboratory (NWQL)]

\begin{tabular}{|c|c|c|c|c|c|c|c|}
\hline & & \multicolumn{6}{|c|}{ Stations where Semipermeable Membrane Devices (SPMD) were deployed } \\
\hline & & $\begin{array}{c}\text { Max } \\
\text { estimated } \\
\text { average } \\
\text { water } \\
\text { concentra- } \\
\text { tion in field } \\
\text { blank }^{1}\end{array}$ & $\begin{array}{l}\text { Portal } \\
\text { Branch } \\
\text { at } \\
\text { Fenwick } \\
\text { Branch } \\
\text { (01647997) }\end{array}$ & $\begin{array}{c}\text { Fenwick } \\
\text { Branch } \\
\text { above } \\
\text { Rock } \\
\text { Creek } \\
\text { (0164799789) }\end{array}$ & $\begin{array}{c}\text { Storm sewer } \\
\text { to Rock } \\
\text { Creek below } \\
\text { Fenwick } \\
\text { Branch } \\
\text { (0164799790) }\end{array}$ & $\begin{array}{c}\text { Rock } \\
\text { Creek } \\
\text { tributary } \\
\text { near } \\
\text { Bingham } \\
\text { Drive } \\
(0164800550) \\
\end{array}$ & $\begin{array}{c}\text { Broad } \\
\text { Branch } \\
\text { above } \\
\text { Soapstone } \\
\text { Valley } \\
(0164801540)\end{array}$ \\
\hline Organochlorine pesticides & Possible or common uses & \multicolumn{6}{|c|}{ Estimated average water concentrations (pg/L) } \\
\hline Benfluralin & Herbicide & 0 & 0 & 26 & 0 & 0 & 25 \\
\hline Dacthal & Herbicide & 0 & 21 & 18 & 0 & 17 & E19 \\
\hline Pendimethalin & Herbicide & 0 & 0 & 0 & 0 & 722 & 0 \\
\hline Trifluralin & \multirow[t]{2}{*}{ Herbicide } & \multirow[t]{2}{*}{0} & \multirow[t]{2}{*}{98} & \multirow[t]{2}{*}{33} & \multirow[t]{2}{*}{46} & \multirow[t]{2}{*}{26} & \multirow[t]{2}{*}{27} \\
\hline $\begin{array}{l}\text { PAHs and related } \\
\text { heterocyclic compounds }\end{array}$ & & & & & & & \\
\hline Anthracene & PAH & 0 & 1,190 & 730 & 1,030 & E264 & E487 \\
\hline Anthraquinone & $\begin{array}{l}\text { Dyes for textiles, bird } \\
\text { repellant }\end{array}$ & 0 & 110,000 & 76,400 & 88,100 & $\mathrm{E} 19,500$ & 27,900 \\
\hline Benzo[a]pyrene & $\begin{array}{l}\text { PAH, formed from incom- } \\
\text { plete combustion of } \\
\text { organic materials }\end{array}$ & 0 & 911 & 537 & 563 & E159 & E295 \\
\hline Fluoranthene & PAH, asphalt, and coal tar & 10 & 48,000 & 24,680 & 27,400 & 2,380 & 8,560 \\
\hline $\begin{array}{l}\text { Hexahydrohexamethyl- } \\
\text { cyclopentabenzopyran } \\
\text { [HHCB] }\end{array}$ & $\begin{array}{l}\text { Fabric softener, soaps, } \\
\text { shampoos }\end{array}$ & 25 & 2,630 & v427 & 1,540 & B & v953 \\
\hline Para-nonylphenol-total & $\begin{array}{l}\text { Nonionic detergent } \\
\text { metabolite }\end{array}$ & 0 & 0 & 0 & $\mathrm{E} 2,660$ & 0 & 0 \\
\hline Polybromodiphenyl ether & Flame retardant & 0 & 0 & 0 & E280 & 0 & E256 \\
\hline Phenanthrene & $\begin{array}{l}\text { PAH, component of tar, } \\
\text { diesel fuel, dyes, drugs, } \\
\text { explosives }\end{array}$ & 64 & 15,500 & 8,480 & 13,600 & $\mathrm{E} 3,100$ & 4,240 \\
\hline Pyrene & PAH, asphalt, and coal tar & 0 & 38,800 & 18,200 & 20,500 & 2,490 & 9,560 \\
\hline Triclosan & Disinfectant, antimicrobial & 0 & 0 & 0 & 2,590 & 0 & 686 \\
\hline Triphenyl phosphate & $\begin{array}{l}\text { Plasticizer, roofing paper, } \\
\text { flame retardant }\end{array}$ & 0 & E165 & 0 & 0 & 0 & 0 \\
\hline
\end{tabular}


Table 11. Estimated average water concentrations from the Semipermeable Membrane Devices (SPMD) deployed in Rock Creek Park, Washington, D.C., July 2 through 29, 2008.-Continued

[pg/L, picograms per liter; PAH, polycyclic aromatic hydrocarbon; an 'E' before a value indicates an estimated concentration near the detection limit for that compound; a " $\mathrm{v}$ " in place of a concentration indicates that the value is questionable because of lab or field contamination; a " $\mathrm{v}$ " in front of a concentration indicates that as much as one third of the concentration may be due to blank contamination; U-DELETED indicates failure of analysis at the lab; results from U.S. Geological Survey National Water Quality Laboratory (NWQL)]

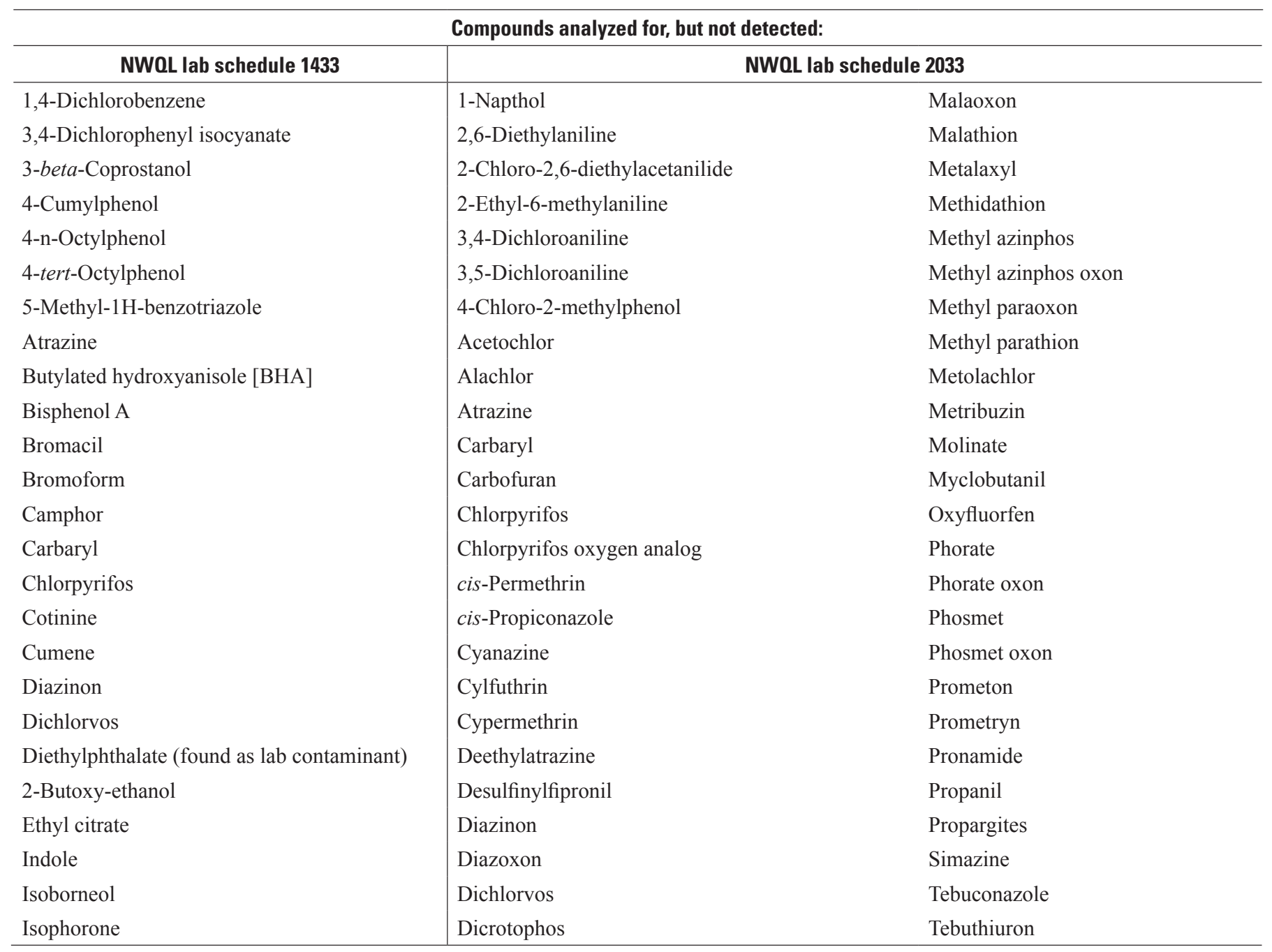


Table 11. Estimated average water concentrations from the Semipermeable Membrane Devices (SPMD) deployed in Rock Creek Park, Washington, D.C., July 2 through 29, 2008.-Continued

[pg/L, picograms per liter; PAH, polycyclic aromatic hydrocarbon; an 'E' before a value indicates an estimated concentration near the detection limit for that compound; a " $\mathrm{v}$ " in place of a concentration indicates that the value is questionable because of lab or field contamination; a " $\mathrm{v}$ " in front of a concentration indicates that as much as one third of the concentration may be due to blank contamination; U-DELETED indicates failure of analysis at the lab; results from U.S. Geological Survey National Water Quality Laboratory (NWQL)]

\begin{tabular}{|c|c|c|c|}
\hline \multicolumn{4}{|c|}{ Compounds analyzed for, but not detected: } \\
\hline NWOL lab schedule 1433 & \multicolumn{3}{|c|}{ NWQL lab schedule 2033} \\
\hline Isoquinoline & Dimethoate & Tefluthrin & Compounds with blank \\
\hline Menthol & Disulfoton & Terbufos & contamination: \\
\hline Metalaxyl & Disulfoton sulfone & Terbufos-O-analog sulfone & 1-Methylnaphthalene \\
\hline Methyl salicylate & Fndosulfan I & Terbuthylazine & 2-6-Dimethylnaphthalene \\
\hline Metolor. & 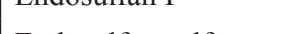 & 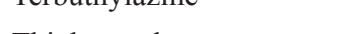 & 2-Methylnaphthalene \\
\hline Metolachlor & Endosulfan sulfate & Thiobencarb & Diethylhexylphthalate \\
\hline$N, N$-diethyl-meta-toluamide [DEET] & Eptam [EPTC] & trans-Permethrin & Naphthalene \\
\hline total NP1EO & Ethion monoxon & trans-Propiconazole & The model does not work for these \\
\hline total NP2EO & Ethoprop & Tribufos & compounds: \\
\hline OP1EO & Fenamiphos & & Acetophenone \\
\hline OP2EO & Fenamiphos sulfone & & beta-Sitosterol \\
\hline para-Cresol & Fenamiphos sulfoxide & & Phenol \\
\hline Pentachlorophenol & Fipronil & & \\
\hline Prometon & Fipronil degradate & & \\
\hline Skatol & Fipronil sulfide & & \\
\hline Stigmastanol & Fipronil sulfone & & \\
\hline Tetrachloroethylene & Fonofos & & \\
\hline Tonalide $[\mathrm{AHTN}]$ & Hexazinone & & \\
\hline Tris(2-chloroethyl)phosphate & Iprodione & & \\
\hline Tris(dichlorisopropyl)phosphate & Isofenphos & & \\
\hline Tributyl phosphate & lambda Cyhalothrin & & \\
\hline
\end{tabular}

Notes:

Concentrations from the lab originally were given in nanograms per amplule of extracted media. Estimates of concentrations in the streams used the SPMD Calculator version 5 created by the U.S. Geological Survey, Columbia Environmental Research Center, Columbia, MO, updated 11/18/2007.

Original concentrations in nanograms per ampule are given in Appendixes F and G.

Discharge measurements were taken at the deployment (July 2) and at the removal (July 29, 2008) of the SPMD.

$1,000,000$ picograms per liter equals 1 microgram per liter. 
Table 12. Normalized concentrations of organic wastewater compounds and pharmaceuticals detected in Polar Organic Chemical Integrative Samplers (POCIS) from five sites in Rock Creek Park, Washington, D.C., July 2 through 29, 2008.-

[POCIS, polar organic chemical integrative sampler; "E" qualifier based on coelution with an interfering compound; "<" qualifier based on interference for that compound (if the compound was there, it would, at least, be below that level.); " $v$ " before a concentration indicates the compound was detected in a blank; results from U.S. Geological Survey National Water Quality Laboratory (NWQL); nd, not detected; ng, nanograms; --, not available]

\begin{tabular}{|c|c|c|c|c|c|c|}
\hline & $\begin{array}{l}\text { Extraction } \\
\text { blank }\end{array}$ & $\begin{array}{c}\text { Portal Branch } \\
\text { above } \\
\text { Fenwick } \\
\text { Branch }\end{array}$ & $\begin{array}{c}\text { Fenwick } \\
\text { Branch } \\
\text { above Rock } \\
\text { Creek }\end{array}$ & $\begin{array}{c}\text { Storm sewer } \\
\text { to Rock } \\
\text { Creek below } \\
\text { Fenwick } \\
\text { Branch }\end{array}$ & $\begin{array}{c}\text { Rock Creek } \\
\text { tributary at } \\
\text { Bingham } \\
\text { Drive }\end{array}$ & $\begin{array}{c}\text { Broad } \\
\text { Branch } \\
\text { above } \\
\text { Soapstone } \\
\text { Valley }\end{array}$ \\
\hline ANALYTES & \multicolumn{6}{|c|}{ Normalized concentration (ng/POCIS) $)^{1}$} \\
\hline NWOL Schedule 2033-Detected Compounds & & & & & & \\
\hline \multicolumn{7}{|l|}{ PESTICIDES } \\
\hline Atrazine & nd & 93.3 & 32.5 & 52.4 & 9.4 & 22.8 \\
\hline 4-Chloro-2-methylphenol & nd & nd & nd & nd & 4.8 & nd \\
\hline Dacthal & nd & 1.2 & 2.1 & nd & nd & 1.9 \\
\hline Deethylatrazine & nd & 117 & 38.6 & 181 & 7.7 & 26.0 \\
\hline Desulfinylfipronil $1^{2}$ & nd & 4.7 & 7.2 & nd & nd & 7.3 \\
\hline 3,4-Dichloroaniline & nd & 28.0 & 6.6 & 618 & $<4.4$ & 10.9 \\
\hline Dieldrin & nd & nd & 7.2 & nd & nd & 8.9 \\
\hline Fipronil & nd & 25.4 & 23.2 & $<28.7$ & nd & 64.5 \\
\hline Fipronil sulfide & nd & 6.4 & 10.2 & nd & $<8.9$ & 11.4 \\
\hline Fipronil sulfone ${ }^{2}$ & nd & $<9$ & 10.9 & nd & 9.7 & E 17.3 \\
\hline Metolachlor & nd & 33.3 & 18.5 & nd & $<6.66$ & 11.1 \\
\hline Myclobutanil & $<3.4$ & nd & 11.3 & nd & 8.9 & 14.4 \\
\hline 1-Napthol & $<3.5$ & 56.3 & 9.7 & 282 & 15.7 & 10.9 \\
\hline Simazine & nd & 47.7 & 19.1 & $<40.6$ & nd & 16.2 \\
\hline Tebuconazole & nd & nd & nd & 70.7 & nd & 73.5 \\
\hline Tebuthiuron & nd & nd & nd & 1,420 & nd & nd \\
\hline Propiconazole, cis + trans & nd & nd & nd & nd & nd & 33.2 \\
\hline Trifluralin & nd & 3.7 & 6.1 & nd & nd & 4.6 \\
\hline \multicolumn{7}{|l|}{$\begin{array}{l}\text { NWOL Schedule 1433-Detected Organic } \\
\text { Wastewater Compounds }\end{array}$} \\
\hline \multicolumn{7}{|l|}{ DETERGENTS AND DEGRADATES } \\
\hline Nonylphenol monoethoxylate [NP1EO]-total & nd & nd & nd & E408 & nd & E213 \\
\hline Nonylphenol diethoxylate [NP2EO]-total & nd & nd & nd & $\mathrm{E} 2,490$ & nd & E815 \\
\hline Octylphenyl monoethoxylate [OP1EO] & nd & nd & nd & E125 & nd & E50 \\
\hline Octylphenyl diethoxylalte [OP2EO] & nd & 89.3 & nd & 292 & nd & nd \\
\hline para-Nonylphenol-total & nd & E202 & $\mathrm{E} 258$ & 646 & E237 & E306 \\
\hline 4-tert-Octylphenol & nd & 61.3 & E37.9 & E107 & E37.1 & nd \\
\hline \multicolumn{7}{|l|}{ ORGANOPHOSPHATE ESTERS } \\
\hline Tris(2-chloroethyl)phosphate & nd & 328 & 194 & E104 & E33.1 & 83.0 \\
\hline Tris(dichlorisopropyl)phosphate & nd & 60.3 & E78 & nd & nd & E52 \\
\hline Tributyl phosphate & nd & nd & nd & E96.2 & nd & nd \\
\hline Triphenyl phosphate & nd & nd & nd & nd & nd & E11.7 \\
\hline
\end{tabular}


Table 12. Normalized concentrations of organic wastewater compounds and pharmaceuticals detected in Polar Organic Chemical Integrative Samplers (POCIS) from five sites in Rock Creek Park, Washington, D.C., July 2 through 29, 2008. - Continued

[POCIS, polar organic chemical integrative sampler; "E" qualifier based on coelution with an interfering compound; "<" qualifier based on interference for that compound (if the compound was there, it would, at least, be below that level.); "v" before a concentration indicates the compound was detected in a blank; results from U.S. Geological Survey National Water Quality Laboratory (NWQL); nd, not detected; ng, nanograms; --, not available]

\begin{tabular}{|c|c|c|c|c|c|c|}
\hline & $\begin{array}{l}\text { Extraction } \\
\text { blank }\end{array}$ & $\begin{array}{l}\text { Portal Branch } \\
\text { above } \\
\text { Fenwick } \\
\text { Branch }\end{array}$ & $\begin{array}{c}\text { Fenwick } \\
\text { Branch } \\
\text { above Rock } \\
\text { Creek }\end{array}$ & $\begin{array}{l}\text { Storm sewer } \\
\text { to Rock } \\
\text { Creek below } \\
\text { Fenwick } \\
\text { Branch }\end{array}$ & $\begin{array}{c}\text { Rock Creek } \\
\text { tributary at } \\
\text { Bingham } \\
\text { Drive }\end{array}$ & $\begin{array}{c}\text { Broad } \\
\text { Branch } \\
\text { above } \\
\text { Soapstone } \\
\text { Valley }\end{array}$ \\
\hline ANALYTES & \multicolumn{6}{|c|}{ Normalized concentration (ng/POCIS) ${ }^{1}$} \\
\hline $\begin{array}{l}\text { NWQL Schedule 1433-Detected Organic } \\
\text { Wastewater Compounds-Continued }\end{array}$ & & & & & & \\
\hline FRAGRANCE/FLAVORANTS & & & & & & \\
\hline Acetophenone & nd & 610 & 352 & 263 & 253 & 401 \\
\hline Benzophenone & E16.3 & vE41.3 & vE46.9 & nd & vE34.8 & vE45.8 \\
\hline $\begin{array}{l}\text { Hexahydrohexamethylcyclopentabenzopyran } \\
\text { [HHCB }]\end{array}$ & nd & E18.2 & nd & E35.3 & nd & E17.5 \\
\hline 3-Methyl-1H-indole [Skatol] & nd & nd & E6.7 & nd & E9.9 & E8.4 \\
\hline Tonalide [AHTN] & nd & E4.6 & nd & nd & nd & E6 \\
\hline \multicolumn{7}{|l|}{ PESTICIDES } \\
\hline Anthraquinone & nd & 79.3 & E66 & E86.0 & nd & E47.1 \\
\hline Atrazine & nd & 87.3 & E42.3 & nd & nd & nd \\
\hline Bromacil & nd & nd & nd & E312 & nd & nd \\
\hline Indole & nd & E45 & E44.5 & E133 & 119.3 & E74 \\
\hline Metolachlor & nd & $\mathrm{E} 32.8$ & E16.7 & nd & nd & nd \\
\hline$N, N$-Diethyl-meta-toluamide [DEET] & nd & 145 & 135 & 272 & E68.7 & 278 \\
\hline \multicolumn{7}{|l|}{ POLYCYCLIC AROMATIC HYDROCARBONS } \\
\hline Anthracene & nd & 69.0 & E47.5 & E29.4 & E18.9 & E30.7 \\
\hline Carbazole & nd & E15.9 & nd & nd & nd & nd \\
\hline Fluoranthene & nd & E15.9 & E12.4 & nd & E9.9 & E18.9 \\
\hline 1-Methylnapthalene ${ }^{3}$ & E2.4 & $\mathrm{vE} 10.3$ & vE5.5 & nd & $\mathrm{vE} 12.1$ & nd \\
\hline 2-Methylnapthalene 3 & E4.4 & vE16.4 & vE9.5 & vE9.48 & vE24.5 & vE6.7 \\
\hline Naphthalene ${ }^{3}$ & E7.9 & vE20.1 & nd & vE19.5 & vE44.6 & vE35.4 \\
\hline Phenanthrene & E11.5 & vE31.2 & vE29.1 & vE18.5 & vE29 & vE44.7 \\
\hline Pyrene & nd & E12.2 & nd & nd & E7.5 & E14.8 \\
\hline \multicolumn{7}{|l|}{ PHARMACEUTICALS } \\
\hline Caffeine & nd & 114.7 & E98 & 257 & nd & 89.5 \\
\hline Cocaine & -- & E22.7 & E14.7 & E25.2 & nd & nd \\
\hline Methyl salicylate & nd & E51.7 & E33.9 & E58.5 & E103 & nd \\
\hline \multicolumn{7}{|l|}{ STEROLS } \\
\hline 3-beta-Coprostanol & nd & nd & nd & nd & nd & E197 \\
\hline beta-Sitosterol & nd & nd & nd & nd & nd & E510 \\
\hline Cholesterol & nd & E563 & E727 & E934 & $\mathrm{E} 1,590$ & $\mathrm{E} 1,460$ \\
\hline Stigmastanol & nd & nd & nd & nd & nd & E319 \\
\hline
\end{tabular}


Table 12. Normalized concentrations of organic wastewater compounds and pharmaceuticals detected in Polar Organic Chemical Integrative Samplers (POCIS) from five sites in Rock Creek Park, Washington, D.C., July 2 through 29, 2008.—Continued

[POCIS, polar organic chemical integrative sampler; "E" qualifier based on coelution with an interfering compound; "<" qualifier based on interference for that compound (if the compound was there, it would, at least, be below that level.); " $v$ " before a concentration indicates the compound was detected in a blank; results from U.S. Geological Survey National Water Quality Laboratory (NWQL); nd, not detected; ng, nanograms; --, not available]

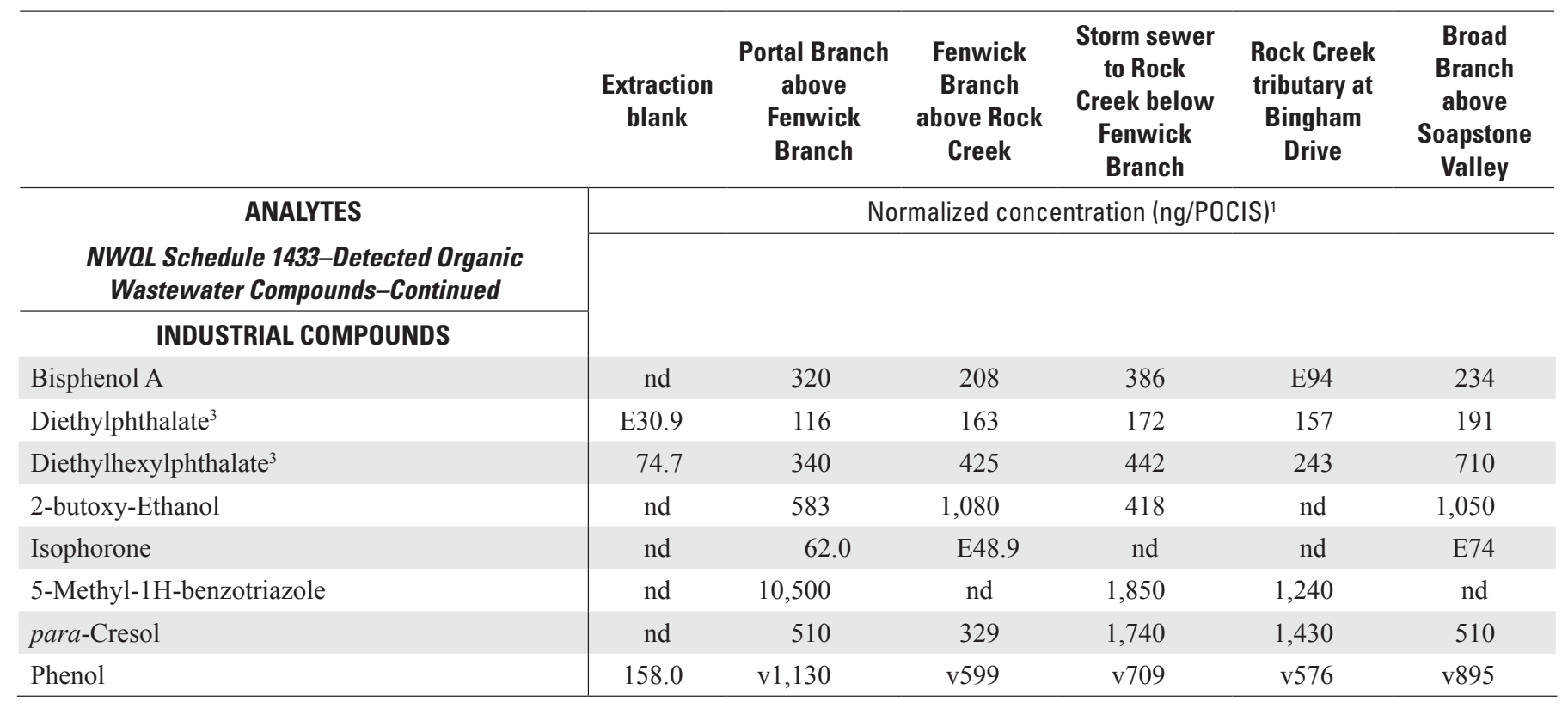


Table 12. Normalized concentrations of organic wastewater compounds and pharmaceuticals detected in Polar Organic Chemical Integrative Samplers (POCIS) from five sites in Rock Creek Park, Washington, D.C., July 2 through 29, 2008. - Continued

[POCIS, polar organic chemical integrative sampler; "E" qualifier based on coelution with an interfering compound; " $<$ " qualifier based on interference for that compound (if the compound was there, it would, at least, be below that level.); "v" before a concentration indicates the compound was detected in a blank; results from U.S. Geological Survey National Water Quality Laboratory (NWQL); nd, not detected; ng, nanograms; --, not available]

\begin{tabular}{|c|c|c|c|}
\hline \multicolumn{4}{|c|}{ ANALYTES NOT DETECTED } \\
\hline NWOL Schedule 1433 & \multicolumn{2}{|c|}{ NWOL Schedule 2033} & Pharmaceuticals \\
\hline Benzo[a]pyrene & Acetochlor & Hexazinone & Butalbital \\
\hline Butylated hydroxyanisole (BHA) & Alachlor & Iprodione & Carisoprodol \\
\hline Bromoform & Benfluralin & Isofenphos & Chloroxylenol \\
\hline Camphor & Carbaryl & Lambda-cyhalothrin & Chlorpheniramine \\
\hline Carbaryl & Carbofuran & Malaoxon & Codeine \\
\hline Chlorpyrifos & 2-Chloro-2,6-diethylacetanilide & Malathion & Diazepan \\
\hline Cotinine & Chlorpyrifos & Metalaxyl & Hydrocodone \\
\hline Cumene & Chlorpyrifos oxygen analog & Methidathion & Methadone \\
\hline Diazinon & cis-Permethrin & Methyl azinphos & Methocarbamol \\
\hline 1,4-Dichlorobenzene & Cyanazine & Methyl azinphos oxon & Metoxalone \\
\hline 3,4-Dichlorophenyl isocyanate & Cylfuthrin & Methyl paraoxon & Oxycodone \\
\hline Dichlorvos & Cypermethrin & Methyl parathion & Phendimetrizine \\
\hline 2,6-Dimethylnapthalene & Diazinon & Metribuzin & \\
\hline d-Limonene & Diazoxon & Molinate & \\
\hline Ethyl citrate & 3,5-Dichloroaniline & Oxyfluorfen & \\
\hline Isoborneol & Dichlorvos & Pendimethalin & \\
\hline Isoquinoline & Dicrotophos & Phorate & \\
\hline Menthol & 2,6-Diethylaniline & Phorate oxon & \\
\hline Metalaxyl & Dimethoate & Phosmet & \\
\hline PBDPE4-2 & Disulfoton & Phosmet oxon & \\
\hline Pentachlorophenol & Disulfoton sulfone & Prometon & \\
\hline 4-Cumylphenol & Endosulfan I & Prometryn & \\
\hline 4-n-Octylphenol & Endosulfan sulfate & Pronamide & \\
\hline Prometon & Eptam [EPTC] & Propanil & \\
\hline Tetrachloroethylene & Ethion & Propargites & \\
\hline Triclosan & Ethion monoxon & Tefluthrin & \\
\hline & Ethoprop & Terbufos & \\
\hline & 2-Ethyl-6-methylaniline & Terbufos-oxygen-analog sulfone & \\
\hline & Fenamiphos & Terbuthylazine & \\
\hline & Fenamiphos sulfone & Thiobencarb & \\
\hline & Fenamiphos sulfoxide & trans-Permethrin & \\
\hline & Fipronil degradate & Tribufos & \\
\hline & Fonofos & & \\
\hline
\end{tabular}

\footnotetext{
${ }^{1}$ Normalized concentrations describe concentration per site. Three POCIS were deployed at each site. At two sites, one or two POCIS were broken and unusable. The extraction process concentrates all analytes from all POCIS into one ampule to be analyzed. If three membranes at one site were extracted, and compared to one POCIS at another site, given equal concentrations in the source water, the site with three intact membranes would have three times the concentration of the site with one intact POCIS. Therefore, each site was normalized by dividing the concentration per ampule by the number of intact POCIS at each site.

${ }^{2}$ Recovery of lab spikes was low; indicates concentrations potentially lower than actual.

${ }^{3}$ These compounds are commonly found in the Semipermeable Membrane Devices (SPMD) that were deployed adjacent to the POCIS and are likely the source of the associated blank contamination.
} 


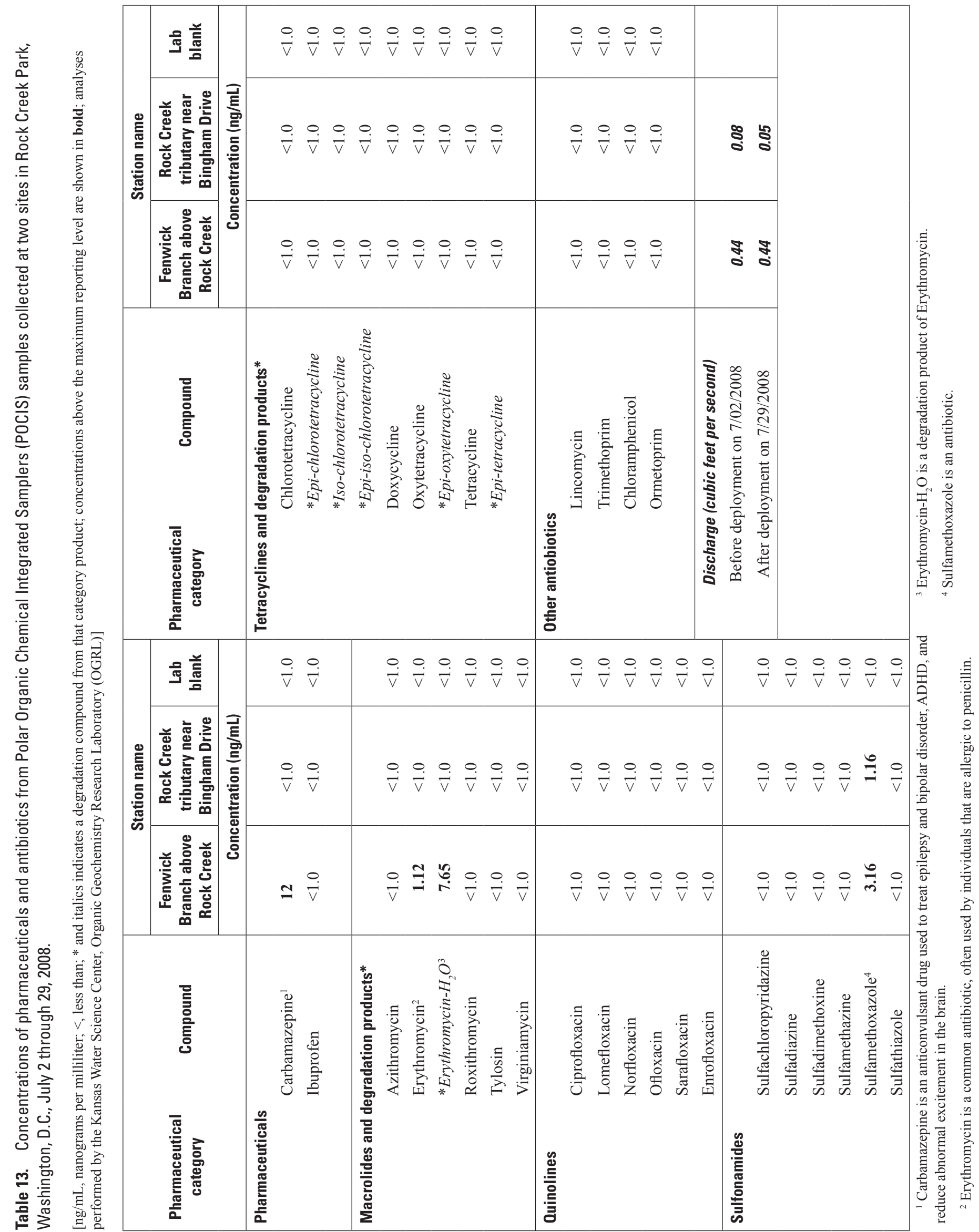




\section{Occurrence and Distribution of Organic Wastewater Compounds in Rock Creek Park}

The 23 sites that were sampled in June 2007 during base-flow conditions were selected on the basis of the results of the TIR data from an overflight in January 2007, in cooperation with NPS personnel who were familiar with the Park infrastructure. The TIR data showed areas where warmer water was discharging to the creek potentially from either groundwater seeps, culverts, or leaky sewer lines. No leaky sewer lines were identified by the TIR data; however, discharge from some open pipes and a storm-sewer outfall was observed. Storm samples were collected from Rock Creek at Joyce Road using an automated sampler during storms in June and September 2008. The POCIS and SPMD passive samplers were placed at the five locations that had the greatest number of detections of OWCs based on results from the 23 base-flow samples. The number of detections was the primary criterion for locating the passive samplers because nearly all concentrations were estimated concentrations near or below detection limits, and using the total concentrations at each site would not represent a valid summation of the concentrations. The five sites selected for the passive-sampler placement were located in the north and west parts of the Park, not in areas to the east and south that were closer to areas affected by the combined CSS system (fig. 3); however, one of the five sites (storm sewer outfall to Rock Creek below Fenwick Branch-fig. 2) was a large (approximately 6-feet diameter) storm drain that was reportedly not connected to the CSO system, but had both physical evidence (gray-colored water discharging during base flow) and chemical evidence (results from synoptic sampling) that it released wastewater-affected runoff into Rock Creek.

During the June 27-28, 2007 base-flow synoptic sampling, there were ubiquitous detections at estimated concentrations of dissolved OWC indicators such as DEET, caffeine, HHCB, and organophosphate flame retardants at more than half of the 23 sites sampled in Rock Creek Park (table 2). Concentrations of DEET and caffeine in the tributaries were variable, but in the main stem of Rock Creek, the concentrations were essentially the same throughout the length of the creek, indicating no increase in concentrations with distance downstream. HHCB was detected in 10 of the tributaries, but not at the main stem Rock Creek sites. Organophosphate flame retardants also were commonly detected in tributaries at concentrations less than $1 \mu \mathrm{g} / \mathrm{L}$, but some samples had concentrations up to $5.6 \mu \mathrm{g} / \mathrm{L}$ (tributary to Fenwick Branch at Red Bud Lane, table 2). Concentrations of organophosphate flame retardants in the main stem Rock Creek were detected at estimated concentrations of $0.2 \mu \mathrm{g} / \mathrm{L}$ or less (table 2), and generally did not increase with distance downstream.

Samples collected at 7 of the 23 sites for whole-water analysis (tables 3 and 6) showed similar patterns for the presence of DEET and organophosphate flame retardants, but caffeine and HHCB were detected in whole water from only 1 or 2 of the 7 sites. Cholesterol and coprostanol (both indicators of OWCs) were detected more often in the whole-water samples than in the dissolved samples, but at similar concentrations. Overall, most wastewater indicators in whole-water samples in the Park had concentrations similar to those found at the upstream sampling station at the MD/DC boundary, indicating that water quality remained constant with distance downstream in the Park. The occurrence of these chemicals during base-flow conditions indicates that there are sources of wastewater coming into the stream; the presence of caffeine may indicate the presence of untreated sewage (Phillips and Chalmers, 2009).

Creek-bottom sediments were collected for analysis of concentrations of OWCs from the same seven sites from which whole-water samples were collected (table 7). The main compounds found in samples collected from bed sediments were PAHs and these occurred at concentrations that were similar to those found in earlier studies in Rock Creek (Anderson and others, 2002; Miller and others, 2006). Cholesterol was found in most of the samples, likely partitioning there preferentially due to its hydrophobicity. There were some detections of OWCs in the creek-bottom sediments, including HHCB and nonylphenol, but no spatial patterns in their occurrence were discerned.

Concentrations of organic compounds in dissolved and whole-water samples were compared to water-quality guidelines for the protection of aquatic life (Canadian Council of Ministers of the Environment (CCME), 2007; U.S. Environmental Protection Agency, 2009). Guidelines or criteria do not currently exist for many of the OWCs; however a few of the CCME guidelines were exceeded, mainly in unfiltered storm samples, and included those for dichlorophenols $(0.2 \mu \mathrm{g} / \mathrm{L})$, benzo[a]pyrene $(0.015 \mu \mathrm{g} / \mathrm{L})$, phenanthrene $(0.4$ $\mu \mathrm{g} / \mathrm{L})$, and pyrene $(0.025 \mu \mathrm{g} / \mathrm{L})$. CCME guidelines for the protection of aquatic life are given in parentheses for each compound, and results for stormwater sampling are presented in Appendix E. Concentrations of OWCs for sediment sampling were similar to concentrations found during previous sampling events (Anderson and others, 2002; Miller and others, 2006), but were not compared because TOC, necessary to normalize values for the comparison, was not measured on sediment in the current study.

The SPMD and POCIS passive-sampling devices consistently collected numerous indicators of wastewater including caffeine, plastic degradates and byproducts of plastic manufacturing, perfumes, detergents and detergent degradates, pesticides, and pharmaceuticals. Some of the compounds were similar to those found in the water samples and indicate that there are likely low-level sources of wastewater entering the stream, particularly at the storm-sewer outfall below Fenwick Branch. The presence of agricultural herbicides such as atrazine, metolachlor, trifluralin, and the atrazine metabolite deethylatrazine, indicates common usage within the basin. Simazine also was found, but this chemical is used for 
agriculture as well as non-selective weed control on roadsides, and thus may have multiple sources. Some of the pesticides found are indicative of more mixed domestic and turf usage, such as the herbicide dacthal (DCPA); fipronil, which is used for flea and tick control on animals; and fungicides, such as propiconazol and myclobutanil. Organophosphate flame retardants, and particularly tris(2-chlorethyl)phosphate, were found consistently in the SPMD samplers. These compounds, along with the nonyl- and octylphenols compounds, are indicators of wastewater. The station with the highest accumulated concentrations was the storm-sewer outfall below Fenwick Branch, indicating that there is a reasonable likelihood that this outfall is a source of wastewater contamination.

The storm samples collected with the automatic sampler at Joyce Road showed generally higher concentrations of OWCs during the second storm (September 6, 2008) than during the first storm (June 27-28, 2008), probably because the September storm had a higher peak discharge $\left(1,970 \mathrm{ft}^{3} / \mathrm{s}\right)$ than the June storm $\left(736 \mathrm{ft}^{3} / \mathrm{s}\right.$, Appendix E). Many of the same OWCs found in base-flow samples and in passive samplers were also found during the two storm events, with some exceptions, within errors, at similar concentrations.

Anthraquinone, an animal/bird repellant often used to control geese on golf courses, was detected in all but the first dissolved June storm samples, at 8 of the 23 base-flow sites, in bottom sediment at the 7 bed-sediment sites, in 4 of 5 POCIS samples, and in 5 of 5 SPMD samples. The overall toxicological risk from human exposure to anthraquinone is currently considered negligible by the U.S. Environmental Protection Agency (USEPA) (http://www.epa.gov/pesticides/ biopesticides/ingredients/factsheets/factsheet_122701.htm).

Atrazine is an herbicide that was detected in whole-water samples at six of the seven sites where whole-water samples were collected at estimated concentrations of up to $0.05 \mu \mathrm{g} / \mathrm{L}$, but it was not detected in any of the dissolved synoptic samples. Sampling by Anderson and others (2002) showed similar concentrations at two of three surface-water sites in the Park, with no detection at the third site. The herbicide was detected in at least 20 percent of samples collected from the Potomac River at Washington, D.C., during 2003-05 (Brayton and others, 2007) at concentrations of up to $1.75 \mu \mathrm{g} / \mathrm{L}$. Metolachlor is another commonly used herbicide that was detected at 10 of the 23 synoptic sites in filtered samples, and at 4 of the 7 sites in whole-water samples, at concentrations similar to those found by Anderson and others (2002). Both herbicides were detected in the storm samples from Joyce Road in most of the June samples, but they were not detected in the September storm samples. Typically, these pesticides are applied in the spring and early summer and concentrations in surface waters peak in the summer (Ator and others, 2004). Atrazine was detected at all five of the passive-sampler sites (table 12), and metolachlor was detected at four of the five passive-sampler sites in July 2008.

Carbaryl is an insecticide that was detected at three surface-water sites in the Park in 2000 (Anderson and others,
2002) at concentrations above water-quality criteria for the protection of aquatic life; however, it was not detected in any of the base-flow samples, stormwater samples, or samples from the passive samplers during this investigation, possibly indicating a reduction in local usage of this compound and the degradation of environmental residues.

Caffeine, an indicator of wastewater effluent, and DEET, an insect repellant, were detected at most of the base-flow sampling sites and in all of the stormwater samples at Joyce Road, indicating the presence of compounds that are ubiquitous in the hydrologic system. Dissolved concentrations of caffeine and DEET in the two sets of storm samples are shown in figures $6 \mathrm{a}$ and $6 \mathrm{~b}$, along with the associated discharge and concentrations of TOC and suspended sediment. The concentration curves for suspended sediment and TOC generally follow the discharge curve. Dissolved concentrations of caffeine and DEET during the June 2008 storm generally rose through the storm (fig. 6a); however, during the September 2006 storm, which had a discharge peak roughly twice that of the June storm, concentrations of caffeine and DEET peaked before the discharge peak, then gradually decreased as discharge remained high (fig. 6b, Appendix E), possibly reflecting differences between the intensities of these two storms.

DEET is a recalcitrant OWC that persists in the environment longer than many of the other OWCs (Focazio and others, 2008; Glassmeyer and others, 2005; Stackelberg and others, 2007). It also persists through the sewage-treatment process and can often be found in treated effluents. Caffeine is more easily degraded by wastewater-treatment processes and thus is more indicative of untreated waste in close proximity to sources of OWCs. During both storms, the concentration of DEET peaked early and stayed elevated over the course of the storms, not showing any dilution effect from the stormwater. This observation indicates storage of this compound in bed sediments that are stirred up and transported during the storms as well as the addition of new sources during surface runoff. The peak in the concentration of caffeine was delayed, not rising during the initial rising limb of the hydrograph. During the smaller June 2008 storm, the concentration of caffeine stayed elevated throughout the storm, but during the September 2008 storm, the concentration decreased later in the storm as higher flow volumes from storm runoff diluted the stream water. A possible scenario for this observation would be sewer lines that leak slowly during base flow but, as storms build up head in the shallow unconfined water table, some of the residuals are flushed into the stream. In larger storms, after this initial residual is flushed out, and the stream water becomes diluted with runoff, then the concentration of caffeine declines. HHCB was generally not found in the storm samples, except for one low-level detection at the leading edge of the September storm. Like caffeine, this is a very easily degraded compound, and would have been expected to follow similar patterns, but perhaps was not found due to differences in detection limits.

Carbazole, a heterocyclic organic compound, has a wide variety of uses and was detected in the bed sediments at each 
(A)

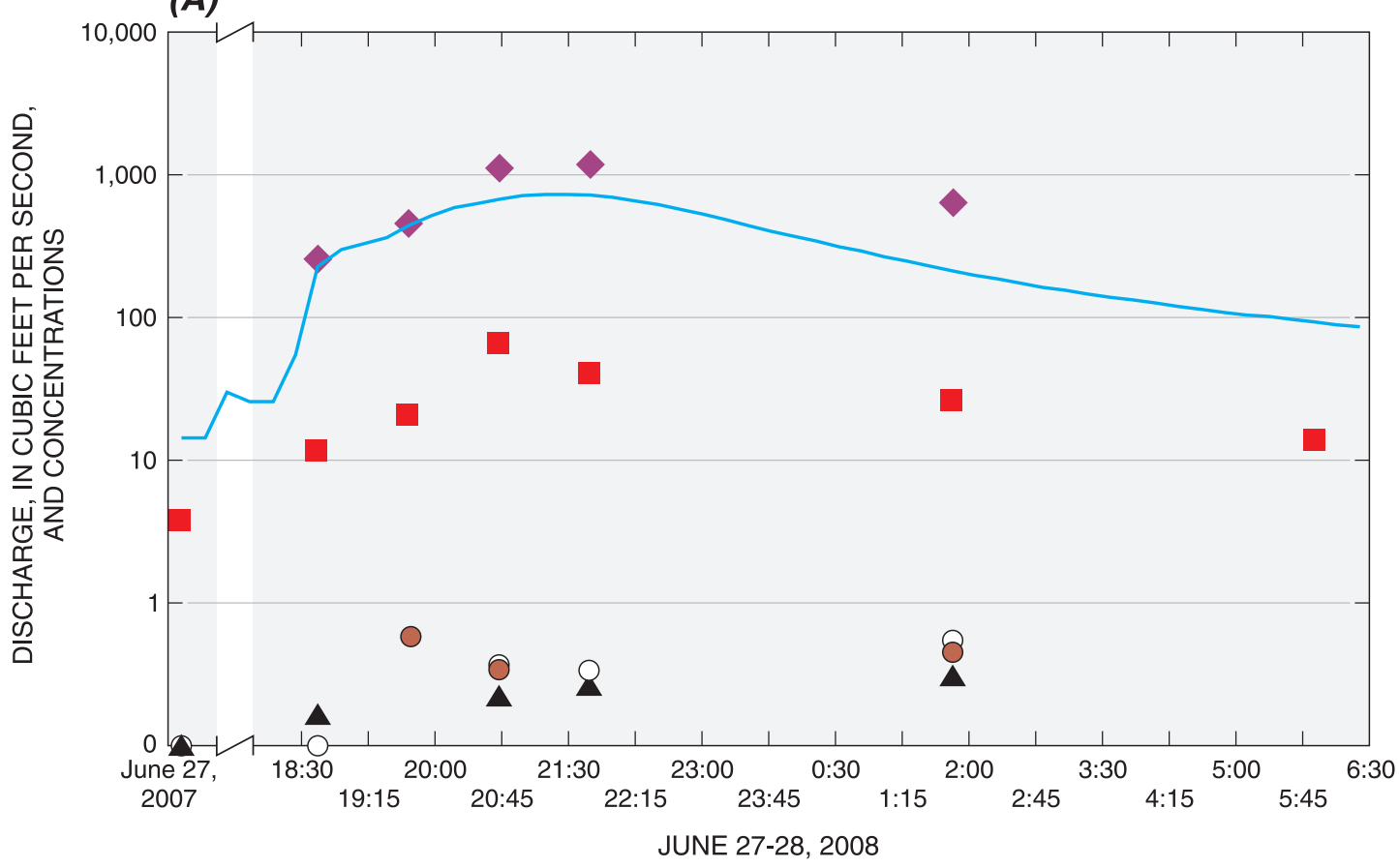

(B)

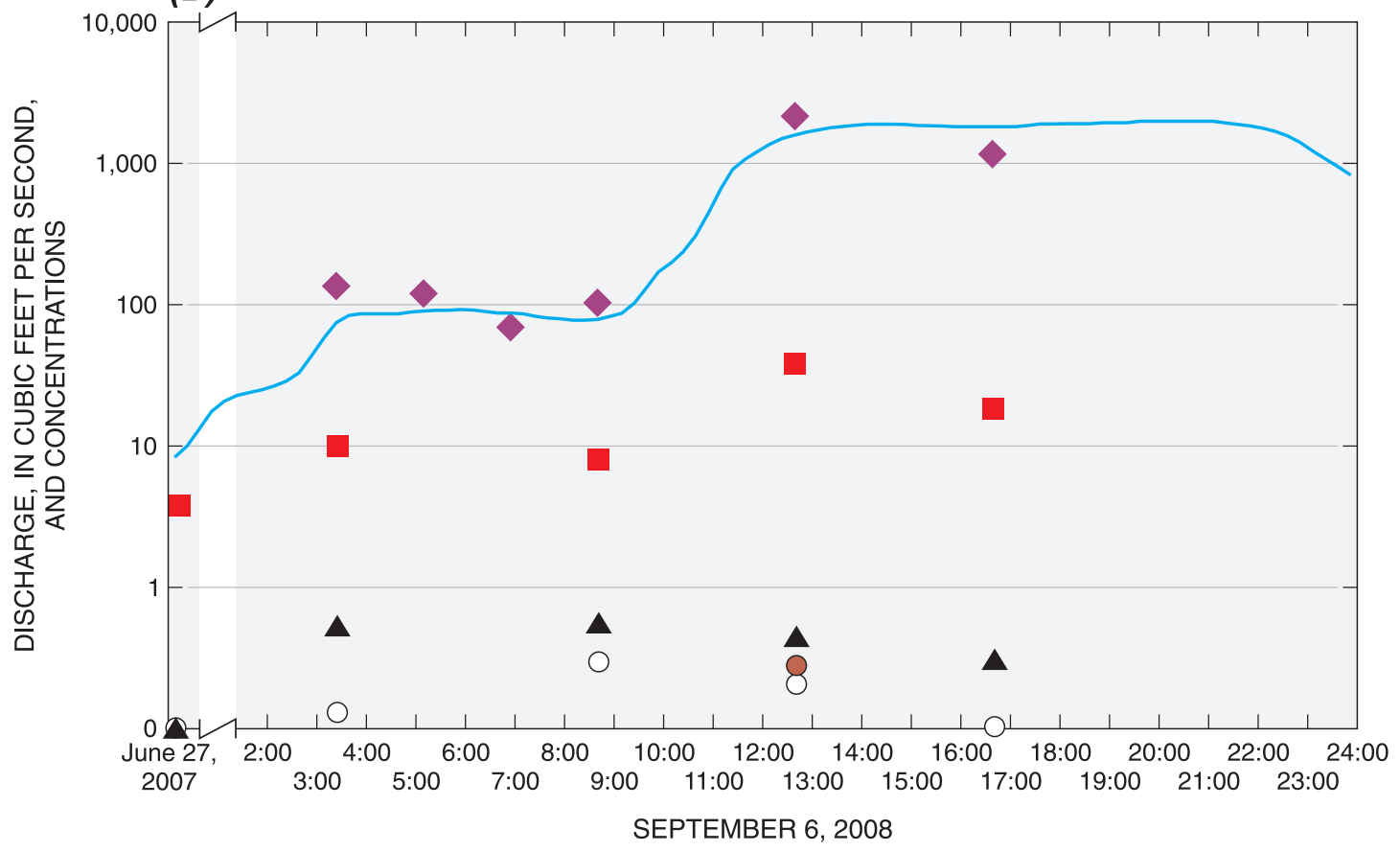

EXPLANATION

DISCHARGE (cubic feet per second)

TOTAL ORGANIC CARBON, TOC (milligrams per liter)

- $\quad N, N$-Diethyl-meta-toluamide [DEET], DISSOLVED (micrograms per liter)
CAFFEINE, DISSOLVED (micrograms per liter)

- CAFFEINE, TOTAL (micrograms per liter)

SEDIMENT (milligrams per liter)

Figure 6. Discharge and concentrations of total organic carbon (TOC), suspended sediment, caffeine, and DEET from Rock Creek at Joyce Road, Washington, D.C., (A) June 27-28, 2008 and (B) September 6, 2008. (Concentrations measured on a base-flow sample collected on June 27, 2007 are shown for comparison.) 
Occurrence and Distribution of Organic Wastewater Compounds in Rock Creek Park, Washington, D.C., 2007-08

of the seven bed-sediment sites in this study, and at each of the three sediment sites in the Anderson (2002) study. In this study, carbazole was detected in about one third of the dissolved stormwater samples, in each of the whole-water storm samples at Joyce Road, but at only 1 of the 23 base-flow sampling sites - at the storm-sewer outfall below Fenwick Branch. The SPMD samplers showed concentrations of carbazole at three of the five passive-sampler sites, including the stormsewer outfall below Fenwick Branch (Appendix F).

Fluoranthene and pyrene, PAHs found in coal tars and asphalts, were detected in all of the storm samples at Joyce Road, in samples from each of the seven sediment sites, and in about one third of the dissolved base-flow samples. High concentrations of each were accumulated in all five SPMD passive samplers over the period of five storms in July 2008 (table 11). Phenanthrene, also a PAH found in coal tars and asphalts, was detected at each sediment site, and had high concentrations accumulated at each of the SPMD sites. Phenanthrene was not detected in dissolved samples during the first storm, but was detected in most of the dissolved samples during the second storm and in each of the whole-water samples from both storms.

PAHs were consistently found in the stormwater samples at Joyce Road, and are ubiquitous contaminants in Rock Creek Park. Each of the individual PAHs was found in higher concentrations in either sediment or whole-water samples than in the dissolved samples collected during base-flow conditions at the 23 synoptic sites, or in the Joyce Road stormwater samples. Sources of PAHs include combustion of fossil fuels, particles from tire wear, lubricating oils, and asphalts and coal tar sealants. Mahler and others (2005) suggested that coal tar sealants that are used on driveways and parking lots are a dominant source of PAHs in urban watersheds, but a detailed analysis of PAH sources in Rock Creek was not conducted as part of this study.

Isophorone is an organic solvent used in a wide variety of applications, and was detected in all the stormwater samples at Joyce Road, but in only 3 of the 23 samples analyzed for dissolved compounds at the base-flow sites, and in none of the whole-water analyses or bottom-sediment samples.

The USGS currently samples $E$. coli bacteria at the Rock Creek at Joyce Road gaging station as part of another study in cooperation with Montgomery County, Maryland. From March through September 2008, 34 water samples were collected, primarily during storms, and analyzed for concentrations of $E$. coli bacteria. The USEPA-recommended (1986) geometric mean densities for E. coli for freshwater recreational areas are not to exceed 126 colony forming units (CFU) per $100 \mathrm{~mL}$ (criteria vary by state). Of the 34 samples collected during that time period, the concentration in only 1 water sample collected at Joyce Road was below the criterion, and the median concentration was 12,000 MPN (most probable number of colonies per $100 \mathrm{~mL}$; U.S. Geological Survey, 2009).

\section{Summary and Conclusions}

The U.S. Geological Survey, and the National Park Service Police Aviation Group, conducted a high-resolution, low altitude aerial thermal infrared survey of the Washington, D.C. section of Rock Creek Basin within the Park boundaries to identify specific locations where warm water from seeps or pipes was discharging to the creek. Twenty-three stream sites in Rock Creek Park were selected based on the thermal infrared images. The 23 sites were sampled during June 2007 and samples were analyzed for concentrations of organic wastewater compounds (OWCs). Two sets of stormwater samples were collected at the Rock Creek at Joyce Road gaging station using an automated refrigerated sampler that began sampling when a specified stage threshold value was exceeded. The first set of storm samples was collected on June 27-28, 2008, and the second set of samples was collected on September 6, 2008. Passive-sampler devices, which accumulate organic wastewater compounds and pesticides over the duration of deployment, were placed in July 2008 at the five locations that had the greatest number of detections of OWCs from the June 2007 base-flow sampling.

During the 2007 base-flow synoptic sampling, there were frequent detections at estimated concentrations of dissolved organic wastewater indicator compounds such as DEET (insect repellant), caffeine (stimulant), HHCB (galaxolide, a common fragrance in cosmetics and detergents), and organophosphate flame retardants at over half of the 23 sites sampled in Rock Creek Park. Concentrations of DEET and caffeine in the tributaries were variable, but in the main stem of Rock Creek, the concentrations were essentially the same throughout the length of the creek, indicating no increase in concentrations with distance downstream. HHCB, an indicator of wastewater, was detected in 10 of the tributaries, but not at the main-stem Rock Creek sites. Organophosphate flame retardants also were commonly detected in tributaries at concentrations less than 1 microgram per liter, but some samples had concentrations up to 5.6 micrograms per liter. Concentrations of organophosphate flame retardants in the main stem of Rock Creek were detected at estimated concentrations of 0.2 micrograms per liter or less and generally did not increase with distance downstream.

Samples collected at 7 of the 23 sites for whole-water analysis showed similar patterns for the presence of DEET and organophosphate flame retardants, but caffeine and HHCB were detected at only one or two of the seven sites sampled for whole-water analyses. Cholesterol and coprostanol (indicators of wastewater) were detected more often in the whole-water samples than in the dissolved samples, but at similar concentrations. Overall, concentrations of most wastewater indicators in whole-water samples in the Park were similar to the concentrations found at the upstream sampling station at the Maryland/Washington, D.C. boundary, indicating little change in concentration with distance downstream in the Park. 
Carbaryl is an insecticide that was detected at three surface-water sites in the Park in 2000 at concentrations above the water-quality criterion for the protection of aquatic life; however, it was not detected in any of the base-flow samples, stormwater samples, or samples from passive samplers during this investigation, possibly indicating a decrease in usage.

Caffeine, an indicator of wastewater, and DEET were detected at most of the base-flow sampling sites, and in all of the stormwater samples at Joyce Road, indicating these compounds are nearly ubiquitous in the hydrologic system. Polycyclic aromatic hydrocarbons were the dominant class of organic compounds in the stormwater samples at Joyce Road. Each of the polycyclic aromatic hydrocarbons was found in higher concentrations in either sediment or whole-water samples than in the dissolved samples from the base-flow sampling at the 23 synoptic sites, or in the Joyce Road stormwater samples.

Creek-bottom samples were collected from the same seven sites from which whole-water samples were also collected, and were analyzed for concentrations of OWCs. The main compounds found in samples collected from bed sediments were polycyclic aromatic hydrocarbons, and these occurred at concentrations that were similar to those found in earlier studies in Rock Creek.

The passive-sampling devices that were installed at the five sites with the highest number of detections during the base-flow sampling consistently collected numerous indicators of wastewater including caffeine, plastic degradates and byproducts of plastic manufacturing, perfumes, detergents and detergent degradates, pesticides, and pharmaceuticals. Some of the compounds were similar to those found in the water samples and indicate that there are likely low-level sources of wastewater entering the stream, particularly at the storm-sewer outfall below Fenwick Branch.

\section{Acknowledgments}

The authors thank Sergeant Ronald Galey, formerly of the National Park Police Aviation Department, Washington, D.C., for planning and organizing the TIR overflight of Rock Creek Park. The authors also thank Officer Keaton Wright, who piloted the Park Police helicopter, and Officer Eric Haapapuro, who operated the TIR camera aboard the helicopter and supplied the images to the USGS. The authors also thank Terri Spencer of EST Labs in St. Joseph, Missouri, for exceptional technical assistance and for her help with the preparation and extraction in the lab of the SPMD and POCIS samplers, and David Alvarez and Edward Furlong of the USGS for guidance in the interpretation of the SPMD and POCIS data. Bill Yeaman, Natural Resource Specialist of Rock Creek Park, and Doug Curtis, Research Hydrologist of the National Park Service, National Capital Region, are thanked for technical assistance during the investigations within the Park.

\section{References Cited}

Alvarez, D.A., Cranor, W.L., Perkins, S.D., Schroeder, V.L., Iwanowicz, L.R., Clark, R.C., Guy, C.P., Pinkney, A.E., Blazer, V.S., and Mullican, J.E., 2009, Reproductive health of bass in the Potomac, USA, drainage: Part 2, Seasonal occurrence of persistent and emerging organic contaminants: Environmental Toxicology and Chemistry, v. 28, no. 5 , p. $1,084-1,095$.

Alvarez, D.A., Huckins, J.N., Petty, J.D., Jones-Lepp, T.L., Stuer-Lauridsen, F., Getting, D.T., Goddard, J.P., and Gravell, A., 2007, Tool for monitoring hydrophilic contaminants in water: Polar organic chemical integrative sampler (POCIS), in Greenwood, R., Mills, G., and Vrana, B., eds., Passive sampling techniques: Amsterdam, Elsevier, Comprehensive Analytical Chemistry, v. 48., p. 171-197.

Alvarez, D.A., Petty, J.D., Huckins, J.N., Jones-Lepp, T.L., Getting, D.T., Goddard, J.P., and Manahan, S.E., 2004, Development of a passive, in situ, integrative sampler for hydrophilic organic contaminants in aquatic environments: Environmental Toxicology and Chemistry, v. 23, no. 7, p. $1,640-1,648$.

Anderson, A.L., Miller, C.V., Olsen, L.D., Doheny, E.J., and Phelan, D.J., 2002, Water quality, sediment quality, and stream-channel classification of Rock Creek, Washington, D.C., 1999-2000: U.S. Geological Survey Water-Resources Investigations Report 02-4067, 91 p., available online at: http://pubs.er.usgs.gov/usgspubs/wri/wri024067.

Ator, S.W., Denver, J.M., and Brayton, M.J., 2004, Hydrologic and geochemical controls on pesticide and nutrient transport to two streams on the Delmarva Peninsula: U.S. Geological Survey Scientific Investigations Report 2004-5050, 34 p.

Banks, W.S.L., Paylor, R.L., and Hughes, W.B., 1996, Using thermal-infrared imagery to delineate ground-water discharge: Ground Water, v. 34, no. 3, p. 434-443.

Barber, L.B., Murphy, S.F., Verplanck, P.L., Sandstrom, M.W., Taylor, H.E., and Furlong, E.T., 2006, Chemical loading into surface water along a hydrological, biogeochemical, and land use gradient: A holistic watershed approach: Environmental Science \& Technology, v. 40, no. 2, p. $475-486$.

Barnes, K.K., Kolpin, D.W., Furlong, E.T., Zaugg, S.D., Meyer, M.T., and Barber, L.B., 2008, A national reconnaissance of pharmaceuticals and other organic wastewater contaminants in the United States-I) Groundwater: Science of the Total Environment, v. 402, nos. 2 and 3, p. 192-200. 
Bradley, P.M., Barber, L.B., Kolpin, D.W., McMahon, P.B., and Chapelle, F.H., 2007, Biotransformation of caffeine, cotinine, and nicotine in stream sediments - Implications for use as wastewater indicators: Environmental

Toxicology and Chemistry, v. 26, no. 6, p. 1,116-1,121, doi: 10.1897/06-483R.1.

Brayton, M.J., Denver, J.M., Delzer, G.C., and Hamilton, P.A., 2007, Organic compounds in Potomac River water used for public supply near Washington, D.C., 2003-05: U.S. Geological Survey Fact Sheet 2007-3085, 6 p., available online at http://pubs.usgs.gov/fs/2007/3085/.

Buerge I.J., Buser, Hans-Rudolf, Müller, M.D., and Poiger, Thomas, 2003, Behavior of the polycyclic musks HHCB and AHTN in lakes, two potential anthropogenic markers for domestic wastewater in surface waters: Environmental Science \& Technology, v. 37, no. 24, p. 5,636-5,644.

Buerge, I.J., Kahle, Maren, Buser, Hans-Rudolf, Müller, M.D., and Poiger, Thomas, 2008, Nicotine derivatives in wastewater and surface waters: Application as chemical markers for domestic wastewater: Environmental Science \& Technology, v. 42 , no. 17 , p. $6,354-6,360$.

Buerge, I.J., Poiger, Thomas, Müller, M.D., and Buser, Hans-Rudolf, 2006, Combined sewer overflows to surface waters detected by the anthropogenic marker caffeine: Environmental Science \& Technology, v. 40, no. 13, p. 4,096-4,102.

Canadian Council of Ministers of the Environment (CCME), 2007, Canadian water quality guidelines for the protection of aquatic life - summary table, in Canadian environmental quality guidelines, 2007: Winnipeg, Canada, Canadian Council of Ministers of the Environment, 9 p.

CH2M HILL, 1977, Rock Creek stormwater and water quality management study, prepared for the Montgomery County Planning Board: CH2M Hill, 409 p.

CH2M HILL, 1979, Rock Creek Basin conservation study, prepared for the National Park Service: CH2M Hill, 366 p.

Childress, C.J.O., Foreman, W.T., Connor, B.F., and Maloney, T.J., 1999, New reporting procedures based on long-term method detection levels and some considerations for interpretations of water-quality data provided by the U.S. Geological Survey National Water Quality Laboratory: U.S. Geological Survey Open-File Report 99-193, 19 p.

Clesceri, L.S., Greenberg, A.E., and Eaton, A.D., eds., 1999, Standard methods for the examination of water and wastewater: Baltimore, Maryland, United Book Press, Inc., American Public Health Association, American Water Works Association, and Water Environment Federation, $1,325 \mathrm{p}$.
Darton, N.H., 1950, Configuration of the bedrock surface of the District of Columbia and vicinity: U.S. Geological Survey Professional Paper 217, 42 p.

District of Columbia Water and Sewer Authority, 2002, WASA's Recommended combined sewer system long term control plan-Control plan highlights, accessed September

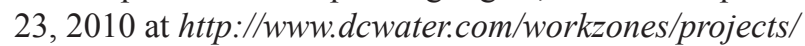
pdfs/ltcp/Control_Plan_Highlights.pdf.

Duigon, M.T., Bolton, D.W., and Cooper, B.F., 2000, The influence of ground water on nitrate loads of streams in the upper Rock Creek Basin, Montgomery County, Maryland: Maryland Geological Survey Open-File Report 2000-02-13, $53 \mathrm{p}$.

Fleming, A.H., Drake, A.A., Jr., and McCartan, Lucy, 1994, Geologic map of the Washington West Quadrangle, District of Columbia, Montgomery and Prince Georges Counties, Maryland, and Arlington and Fairfax Counties, Virginia: U.S. Geological Survey Geologic Quadrangle Map GQ-1748, 1 sheet.

Focazio, M.J., Kolpin, D.W., Barnes, K.K., Furlong, E.T., Meyer, M.T., Zaugg, S.D., Barber, L.B., and Thurman, M.E., 2008, A national reconnaissance for pharmaceuticals and other organic wastewater contaminants in the United States-II) Untreated drinking water sources: Science of the Total Environment, v. 402, nos. 2-3, p. 201-216.

Glassmeyer, S.T., Furlong, E.T., Kolpin, D.W., Cahill, J.D., Zaugg, S.D., Werner, S.L., Meyer, M.T., and Kryak, D.D., 2005, Transport of chemical and microbial contaminants from known wastewater discharges: Potential for use as indicators of human fecal contamination: Environmental Science and Technology, v. 39, no. 14, p. 5,157-5,169.

Huckins J.N., Petty J.D., and Booij, K., 2006, Monitors of organic chemicals in the environment-Semipermeable Membrane Devices: New York, Springer, 223 p.

Huckins, J.N., Petty, J.D., Prest, H.F., Clark, R.C., Alvarez, D.A., Orazio, C.E., Lebo, J.A., Cranor, W.L., and Johnson, B.T., 2002, A guide for the use of semipermeable membrane devices (SPMD) as samplers of waterborne hydrophobic organic contaminants: Washington D.C., Report for the American Petroleum Institute (API), API publication number 4690 .

International Joint Commission of United States and Canada, 1989, Great Lakes water quality agreement of 1978, accessed July 30, 2009, at http://www.ijc.org/rel/agree/ quality. html. 
Kolpin, D.W., Furlong, E.T., Meyer, M.T., Thurman, E.M., Zaugg, S.D., Barber, L.B., and Buxton, H.T., 2002, Pharmaceuticals, hormones, and other organic wastewater contaminants in U.S. streams, 1999-2000-A national reconnaissance: Environmental Science and Technology, v. 36 , no. 6 , p. 1,202-1,211.

Kolpin, D.W., Skopec, M., Meyer, M.T., Furlong, E.T., and Zaugg, S.D., 2004, Urban contribution of pharmaceuticals and other organic wastewater contaminants to streams during different flow conditions: Science of the Total Environment, v. 328, p. 119-130.

Mahler, B.J., Van Metre, P.C., Bashara, T.J., Wilson, J.T., and Johns, D.A., 2005, Parking lot sealcoat: An unrecognized source of urban polycyclic aromatic hydrocarbons: Environmental Science and Technology, v. 39, no. 15, p. 5,560-5,566.

Majcher, E.H., Phelan, D.J., Lorah, M.M., and McGinty, A.L., 2007, Characterization of preferential ground-water seepage from a chlorinated hydrocarbon-contaminated aquifer to West Branch Canal Creek, Aberdeen Proving Ground, Maryland, 2003-04: U.S. Geological Survey Scientific Investigations Report 2006-5233, 191 p., available online at http://pubs.usgs.gov/sir/2006/5233/.

Maryland-National Capital Park and Planning Commission, 1999, Environmental resources inventory for the upper Rock Creek Basin: Silver Spring, Maryland, MarylandNational Capital Park and Planning Commission, 70 p.

Meyer, M.T., Lee, E.A., Ferrell, G.F., Bumgarner, J.E., and Varns, Jerry, 2007, Evaluation of offline tandem and online solid-phase extraction with liquid chromatography/electrospray ionization-mass spectrometry for analysis of antibiotics in ambient water and comparison to an independent method: U.S. Geological Survey Scientific Investigations Report 2007-5021, 28 p., available online at http://pubs. usgs.gov/sir/2007/5021/pdf/SIR20075021.pdf.

Miller, C.V., Weyers, H.S., Blazer, V.S., and Freeman, M.E., 2006, Chemical and ecological health of white sucker (Catostomus commersoni) in Rock Creek Park, Washington, D.C., 2003-04: U.S. Geological Survey Scientific Investigations Report 2006-5140, 37 p., available online at http://pubs.usgs.gov/sir/2006/5140.

Phillips, P.J., and Chalmers, A.T., 2009, Wastewater effluent, combined sewer overflows, and other sources of organic compounds to Lake Champlain: Journal of the American Water Works Association, v. 45, no. 1, p. 45-57.

Portnoy, J.W., Nowicki, B.L., Roman, C.T., and Urish, D.W., 1998, The discharge of nitrate-contaminated groundwater from developed shoreline to marsh-fringed estuary: Water Resources Research, v. 34, no. 11, p. 3,095-3,104.
Sherman, L.K., and Horner, W.W., 1935, Report on measure and elimination of pollution of Rock Creek and its tributaries in Washington, Federal Project Number 607: U.S. Department of the Interior, National Park Service, $74 \mathrm{p}$.

Stackelberg, P.E., Gibs, Jacob, Furlong, E.T., Meyer, M.T., Zaugg, S.D., and Lippincott, R.L., 2007, Efficiency of conventional drinking-water-treatment processes in removal of pharmaceuticals and other organic compounds: Science of the Total Environment 377, available online at: http://www. neiwpcc.org/ppcpconference/ppcp-docs/PaulStackelberg/ Stackelberg\%20et\%20al\%202007.pdf, p. 255-272.

Torgersen, C.E., Faux, R.N., McIntosh, B.A., Poage, N.J., and Norton, D.J., 2001, Airborne thermal remote sensing for water temperature assessment in rivers and streams: Remote Sensing of the Environment, v. 76, no. 3, p. 386-398.

U.S. Environmental Protection Agency, 1986, Ambient water quality criteria for bacteria: Office of Water, Publication Number EPA440/5-84-002, 18 p.

U.S. Environmental Protection Agency, 1999, National recommended water-quality criteria-correction: Office of Water, Publication Number EPA 822-Z-99-007, 25 p.

U.S. Environmental Protection Agency, 2009, National recommended water-quality criteria, 21 p., available online at: http://www.epa.gov/waterscience/criteria/wqctable/nrwqc2009.pdf.

U.S. Geological Survey, 2009, Annual water data report, water year 2008, Maryland-Delaware-District of Columbia, Rock Creek at Sherill Drive data are available online at $h t t p: / / w d r$. water.usgs.gov/wy2008/pdfs/01648000.2008.pdf (accessed 8/12/2008), [variously paged].

Van Metre, P.C., and Mahler, B.J., 2005, Trends in hydrophobic organic contaminants in urban and reference lake sediments across the United States, 1970-2001: Environmental Science and Technology, v. 39, no. 15, p. 5,567-5,574.

Weigel, S., Berger, U., Jensen, E., Kallenborn, R., Thorensen, H., and Hühnerfuss, H., 2004, Determination of selected pharmaceuticals and caffeine in sewage and seawater from Tromso, Norway with emphasis on ibuprofen and its metabolites: Chemosphere, v. 56, no. 6, p. 583-592.

York, T.H., and Herb, W.J., 1978, Effects of urbanization on streamflow and sediment transport in the Rock Creek and Anacostia River Basins, Montgomery County, Maryland, 1962-74: U.S. Geological Survey Professional Paper 1003, $71 \mathrm{p}$. 
Zaugg, S.D., Smith, S.G., and Schroeder, M.P., 2006, Methods of analysis by the U.S. Geological Survey National Water Quality Laboratory-Determination of wastewater compounds in whole water by continuous liquid-liquid extraction and capillary-column gas chromatography/mass spectrometry: U.S. Geological Survey Techniques and Methods, book 5, chap. B4, $30 \mathrm{p}$.

Zaugg, S.D., Smith, S.G., Schroeder, M.P., Barber, L.B., and Burkhardt, M.R., 2006, Methods of analysis by the U.S. Geological Survey National Water Quality LaboratoryDetermination of wastewater compounds by polystyrenedivinylbenzene solid-phase extraction and capillary-column gas chromatography/mass spectrometry: U.S. Geological Survey Water-Resources Investigations Report 01-4186, 37 p., available online at http://pubs.usgs.gov/wri/ wri014186/. 


\section{Appendixes A-G}


Appendix A. Selected images from thermal infrared flyover of Rock Creek Park, Washington, D.C., at dawn, January $31,2007$.

\begin{tabular}{cccl}
\hline Image number & $\begin{array}{c}\text { Approximate location } \\
\text { from fig. 2 }\end{array}$ & $\begin{array}{c}\text { U.S. Geological Survey } \\
\text { station number }\end{array}$ & \multicolumn{1}{c}{$\begin{array}{c}\text { U.S. Geological Survey } \\
\text { station name/location of image }\end{array}$} \\
\hline $\mathbf{1}$ & $\mathrm{E}$ & 0164799790 & Storm-sewer inflow to Rock Creek below Fenwick Branch \\
$\mathbf{2}$ & $\mathrm{F}$ & 01648001 & Whittier Run above Rock Creek \\
$\mathbf{3}$ & $\mathrm{J}$ & 0164800550 & Inflow upstream from Rock Creek tributary near Bingham Drive \\
$\mathbf{4}$ & $\mathrm{L}$ & 01648011 & Upstream end of Luzon Branch at Joyce Road \\
\hline
\end{tabular}

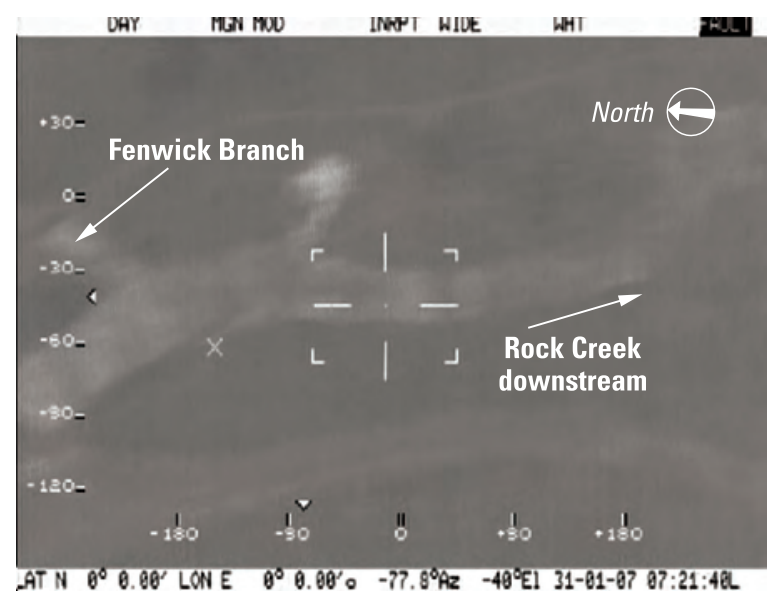

Image 1. Storm-sewer inflow to Rock Creek below Fenwick Branch.

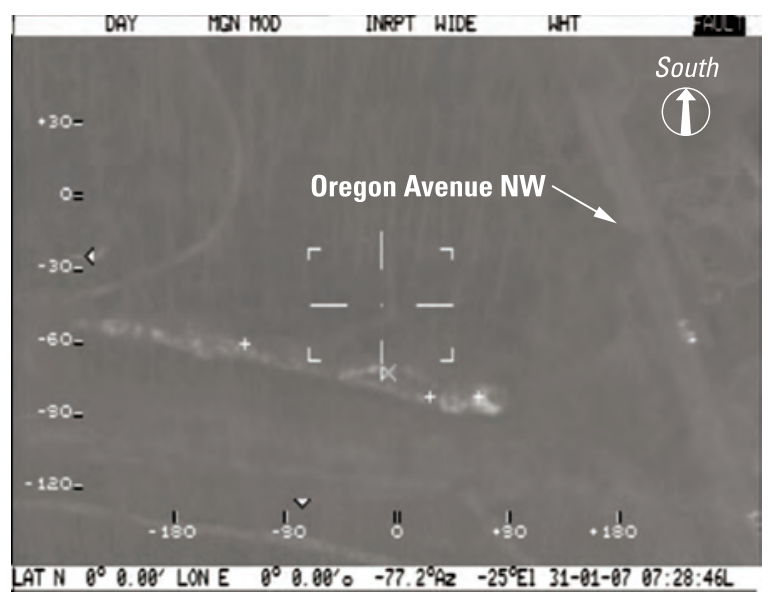

Image 3. Inflow upstream from Rock Creek tributary near Bingham Drive.

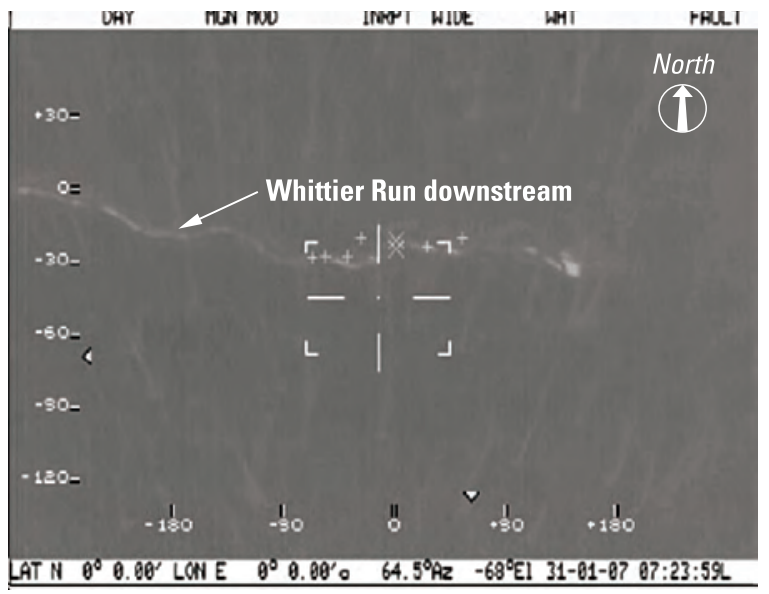

Image 2. Whittier Run above Rock Creek.

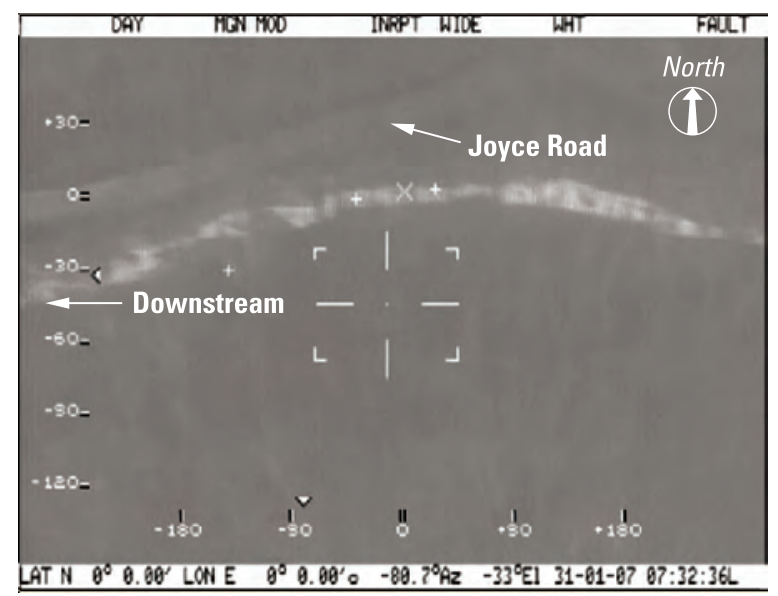

Image 4. Upstream end of Luzon Branch at Joyce Road. 
Appendix A. Selected images from thermal infrared flyover of Rock Creek Park, Washington, D.C., at dawn, January 31, 2007. -Continued

\begin{tabular}{cccc}
\hline Image number & $\begin{array}{c}\text { Approximate location } \\
\text { from fig. 2 }\end{array}$ & $\begin{array}{c}\text { U.S. Geological Survey } \\
\text { station number }\end{array}$ & $\begin{array}{c}\text { U.S. Geological Survey } \\
\text { station name/location of image }\end{array}$ \\
\hline $\mathbf{6}$ & $\mathrm{R}$ & 01648390 & Normanstone Creek above Rock Creek \\
\hline $\mathbf{8}$ & $\mathrm{V}$ & 01649000 & Pipe inflow to Rock Creek below P Street \\
\hline
\end{tabular}

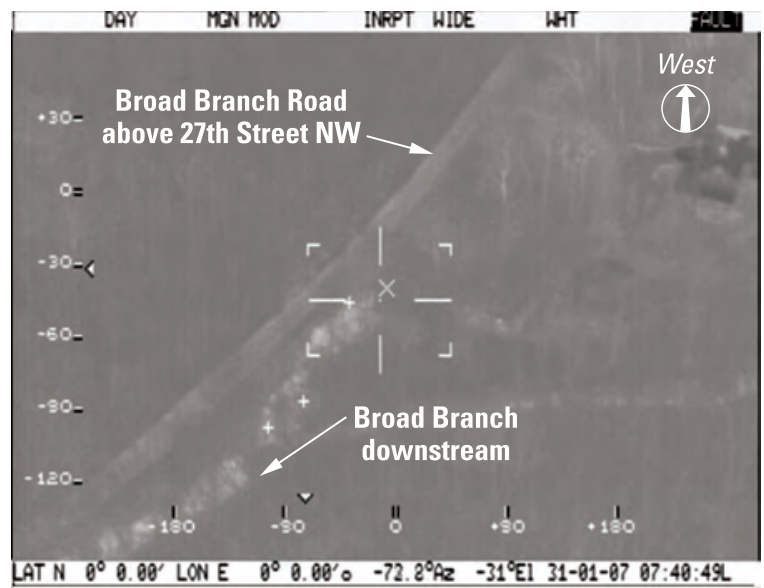

Image 5. Upstream end of Broad Branch above Soapstone Valley.

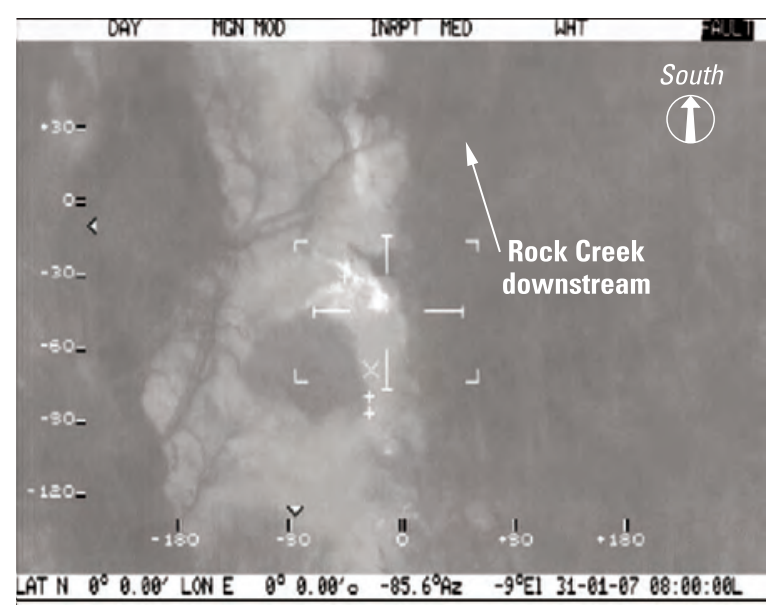

Image 7. Upstream from Rock Creek at Q Street.

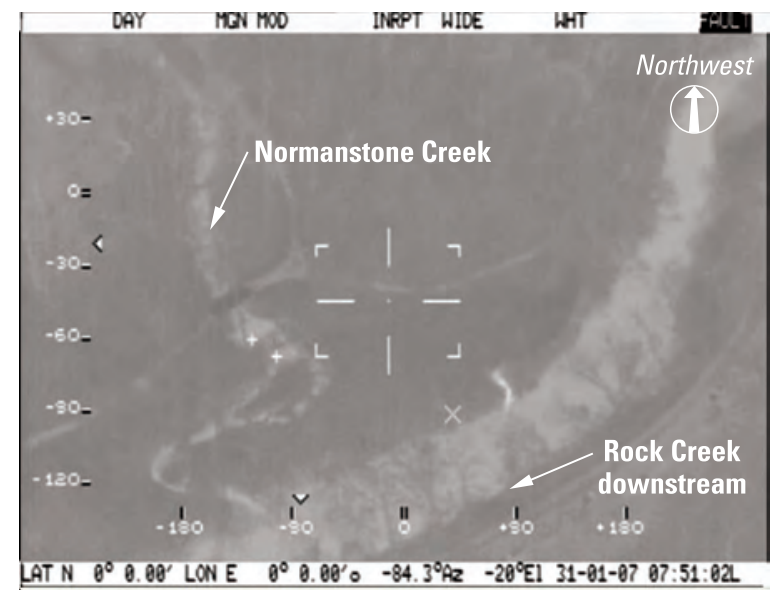

Image 6. Normanstone Creek above Rock Creek.

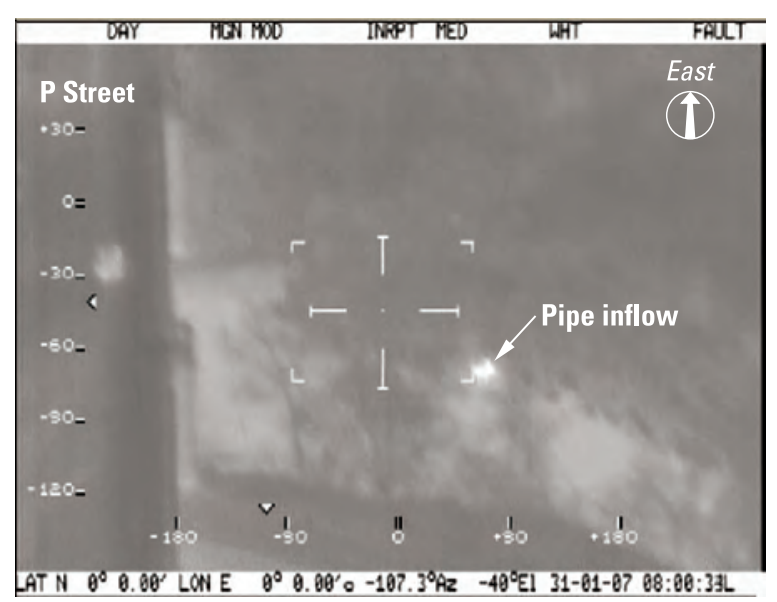

Image 8. Pipe inflow to Rock Creek below P Street. 
Appendix B. Organic wastewater compounds analyzed in filtered surface-water samples from Rock Creek Park, Washington, D.C., June 27-28, 2007.

[Compounds detected are shown in bold. Detected concentrations shown in table 2; LRL, lower reporting limits for each compound are given after the compound, in micrograms per liter; U, result deleted by lab; analyzed by the U.S. Geological Survey National Water Quality Laboratory, Denver, CO, Schedule 1433]

\begin{tabular}{|c|c|c|c|c|c|}
\hline Compound & LRL & Compound & LRL & Compound & LRL \\
\hline Anthraquinone & 0.16 & $N, N,-$ Diethyl-meta-toluamide [DEET] & 0.2 & 5-Methyl-1H-benzotriazole & 0.08 \\
\hline Acetophenone & 0.1 & Diazinon & 0.16 & 3-Methyl-1H-indone [Skatol] & 0.08 \\
\hline Anthracene & 0.08 & Diethoxynonylphenol & 5.0 & Monoethoxyoctylphenol & 1.0 \\
\hline beta-Stigmastanol & 2.0 & Ethoxyoctylphenol & 1.0 & 4-Octylphenol & 0.16 \\
\hline Bromacil & 0.4 & Fluoranthene & 0.08 & 4-tert-Octylphenol & 0.1 \\
\hline 3-Butyl-4-hydroxyanisole [BHA] & 0.6 & $\begin{array}{l}\text { Hexahydrohexamethylcyclopentaben- } \\
\text { zopyran [HHCB] }\end{array}$ & 0.5 & Phenanthrene & 0.1 \\
\hline Carbazol & 0.08 & Isopropylbenzene [Cumene] & 0.1 & beta-Sitosterol & 2.0 \\
\hline Chlorpheniramine & 0.04 & Isoquinoline & 0.4 & Tetrachloroethylene & 0.2 \\
\hline Chlorpyrifos & 0.2 & $d$-Limonene & 0.1 & Tribromomethane & 0.1 \\
\hline Cholesterol & 1.0 & Metalaxyl & 0.2 & Tributyl phosphate & 0.2 \\
\hline 3-beta-Coprostanol & 1.6 & Metaxalone & 4.0 & Tris(2-butoxyethyl)phosphate & 0.05 \\
\hline Bisphenol A & $\mathrm{U}$ & Methadone & 0.4 & Triclosan & 0.2 \\
\hline Butalbital & 0.4 & 1-Methylnaphthalene & 0.1 & $\begin{array}{l}\text { Tris(2-chloroethyl)phosphate } \\
\text { [FYROL CEF] }\end{array}$ & 0.2 \\
\hline Cotinine & 0.4 & 2-Methylnaphthalene & 0.08 & $\begin{array}{l}\text { Tris(dichloroisopropyl)phos- } \\
\text { phate [FYROL PCF] }\end{array}$ & 0.2 \\
\hline
\end{tabular}


Appendix C. Organic wastewater compounds for which surface-water samples were analyzed in unfiltered water in Rock Creek Park, Washington, D.C., June 27-28, 2007.

[Compounds detected for total analysis are shown in bold; see table 6 for concentrations of detected compounds; LRL, lower reporting limits for each compound are given after the compound, in micrograms per liter; analyzed by the U.S. Geological Survey National Water Quality Laboratory, Denver, CO, Schedule 4433]

\begin{tabular}{|c|c|c|c|c|c|}
\hline Compound & LRL & Compound & LRL & Compound & LRL \\
\hline Acetophenone & 0.4 & Dichlorvos & 0.2 & Monoethoxyoctylphenol [OP1EO] & 1 \\
\hline $\begin{array}{l}\text { Acetyl hexamethyltetrahydronaphthalene } \\
\text { [AHTN] }\end{array}$ & 0.2 & Diethoxyoctylphenol [OP2EO] & 0.32 & Naphthalene & 0.2 \\
\hline Anthracene & 0.2 & Diethyl phthalate & 0.2 & para-Nonylphenol total & 1.6 \\
\hline Anthraquinone & 0.2 & $\begin{array}{l}N, N,- \text { Diethyl-meta-toluamide } \\
\quad[\text { DEET] }\end{array}$ & 0.2 & Phenanthrene & 0.2 \\
\hline Benzo[a]pyrene & 0.2 & 2,6-dimethylnaphthalene & 0.2 & 4-n-Octylphenol & 0.2 \\
\hline Benzophenone & 0.2 & Fluoranthene & 0.2 & 4-tert-Octylphenol & 0.2 \\
\hline Bisphenol A & 0.4 & $\begin{array}{l}\text { Hexahydrohexamethylcyclo- } \\
\text { pentabenzopyran [HHCB] }\end{array}$ & 0.2 & Pentachlorophenol & 0.8 \\
\hline Camphor & 0.2 & Isopropylbenzene [Cumene] & 0.2 & beta-Stigmastanol & 0.8 \\
\hline Carbaryl & 0.2 & Isoquinoline & 0.2 & bis-(2-Ethylhexyl)phthalate [DEHP] & 2 \\
\hline Carbazole & 0.2 & d-Limonene & 0.2 & $\begin{array}{l}\text { 3-tert-Butyl-4-hydroxyanisole } \\
\text { [BHA] }\end{array}$ & 0.2 \\
\hline Chlorpyrifos & 0.2 & Menthol & 0.2 & 2,2',4,4'-tetrabromodiphenyl ether & 0.2 \\
\hline Cholesterol & 0.8 & Methylaxyl & 0.2 & Tetrachloroethylene & 0.4 \\
\hline 3-beta-Coprostanol & 0.8 & 5-Methyl-1H-benzotriazole & 1.6 & Tris(2-butoxyethyl)phosphate & 0.2 \\
\hline Cotinine & 0.8 & 1-Methylnaphthalene & 0.2 & Tributyl phosphate & 0.2 \\
\hline para-Cresol & 0.2 & 2-Methylnapthalene & 0.2 & $\begin{array}{l}\text { Tris(2-chloroethyl)phosphate } \\
\text { [FYROL CEF] }\end{array}$ & 0.2 \\
\hline
\end{tabular}


Appendix D. Organic wastewater compounds for which creek-bottom-sediment samples were analyzed in Rock Creek Park, Washington, D.C., June 27-28, 2007.

[Compounds detected are shown in bold; see table 7 for concentrations of detected compounds; LRL range, either the lower reporting limit, or the range ( $\mathrm{min} / \mathrm{max}$ ) of lower reporting limits for each compound are given after the compound, in micrograms per kilogram; analyzed by the U.S. Geological Survey National Water Quality Laboratory, Denver, CO, Schedule 5433]

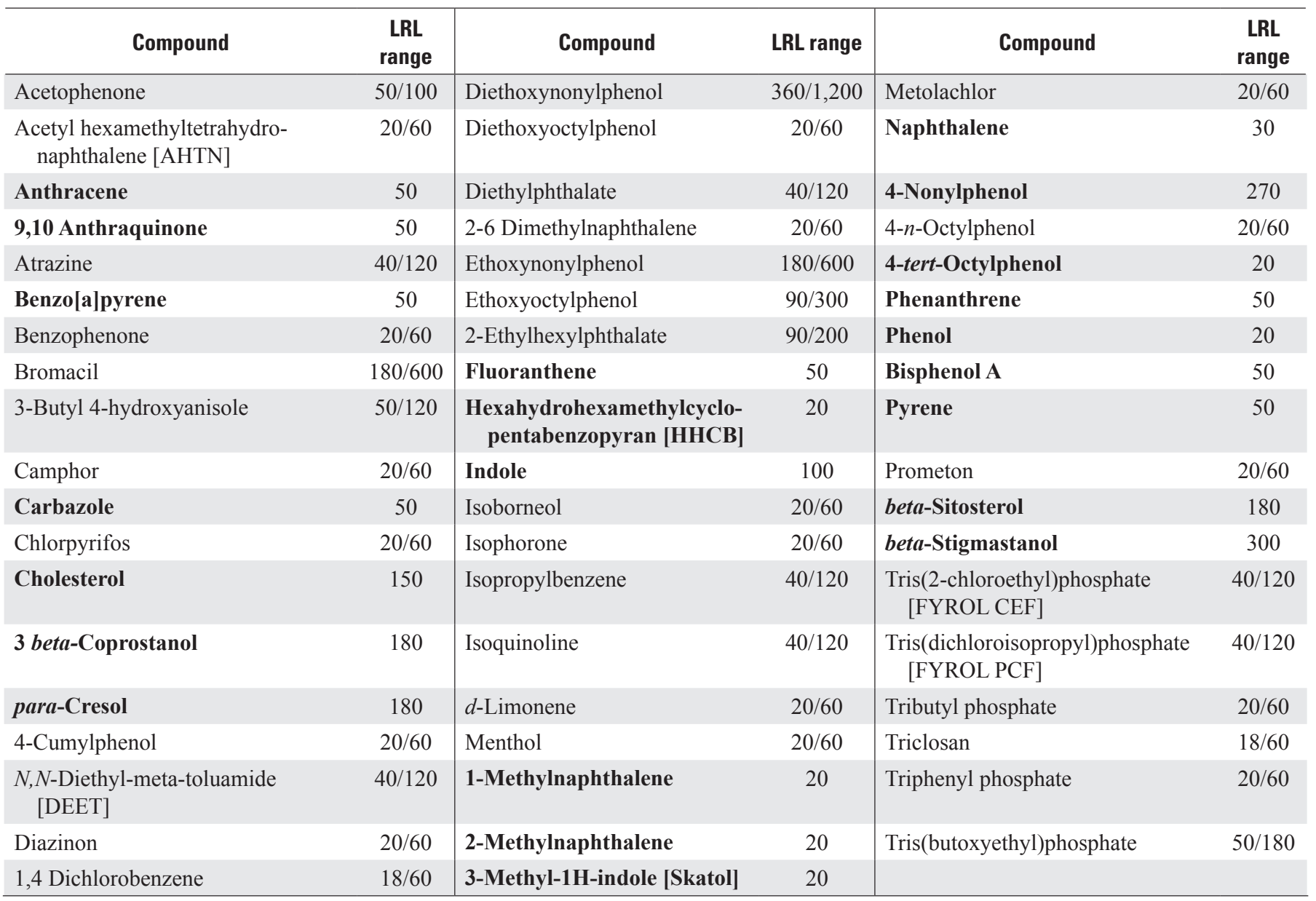




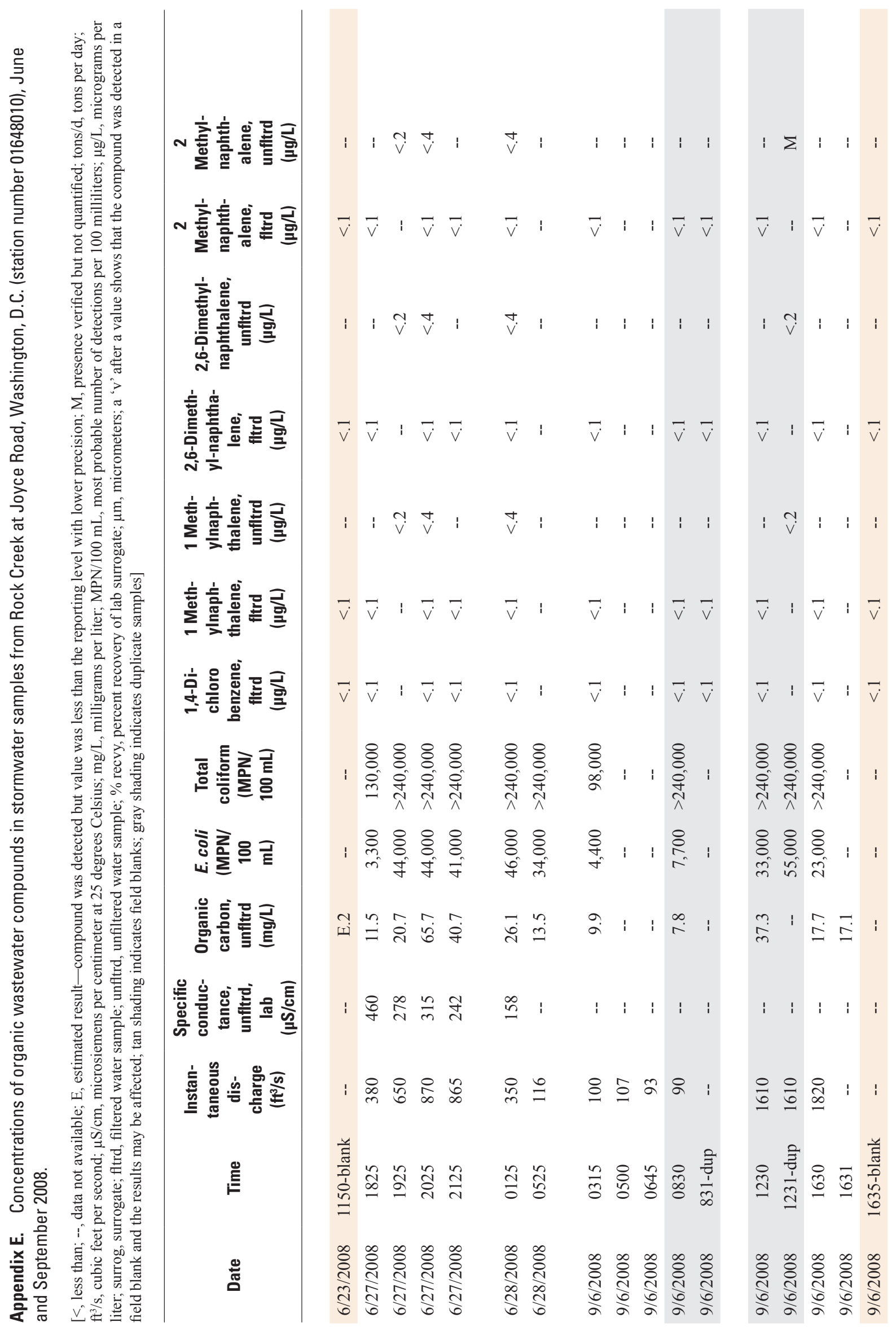




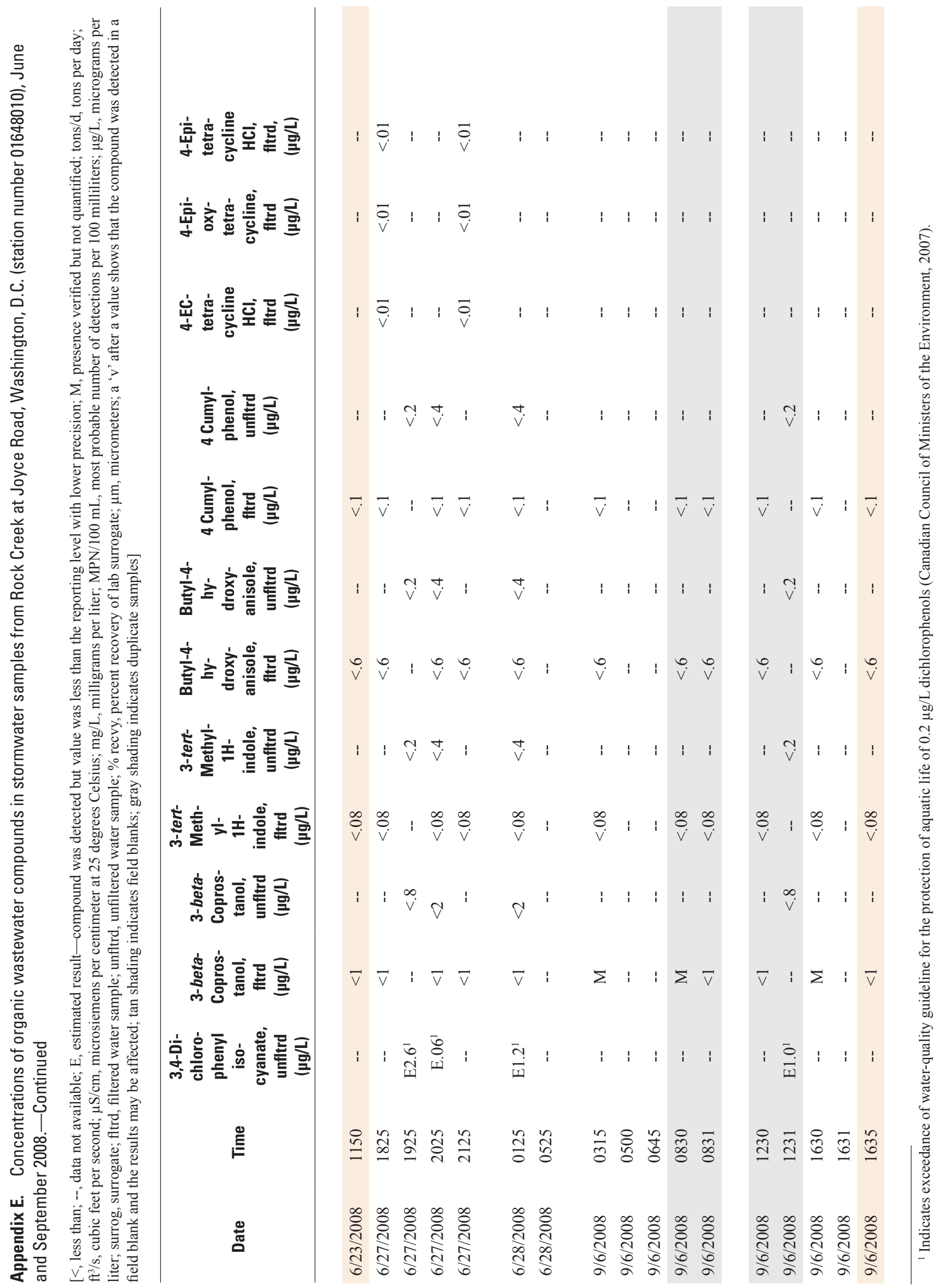




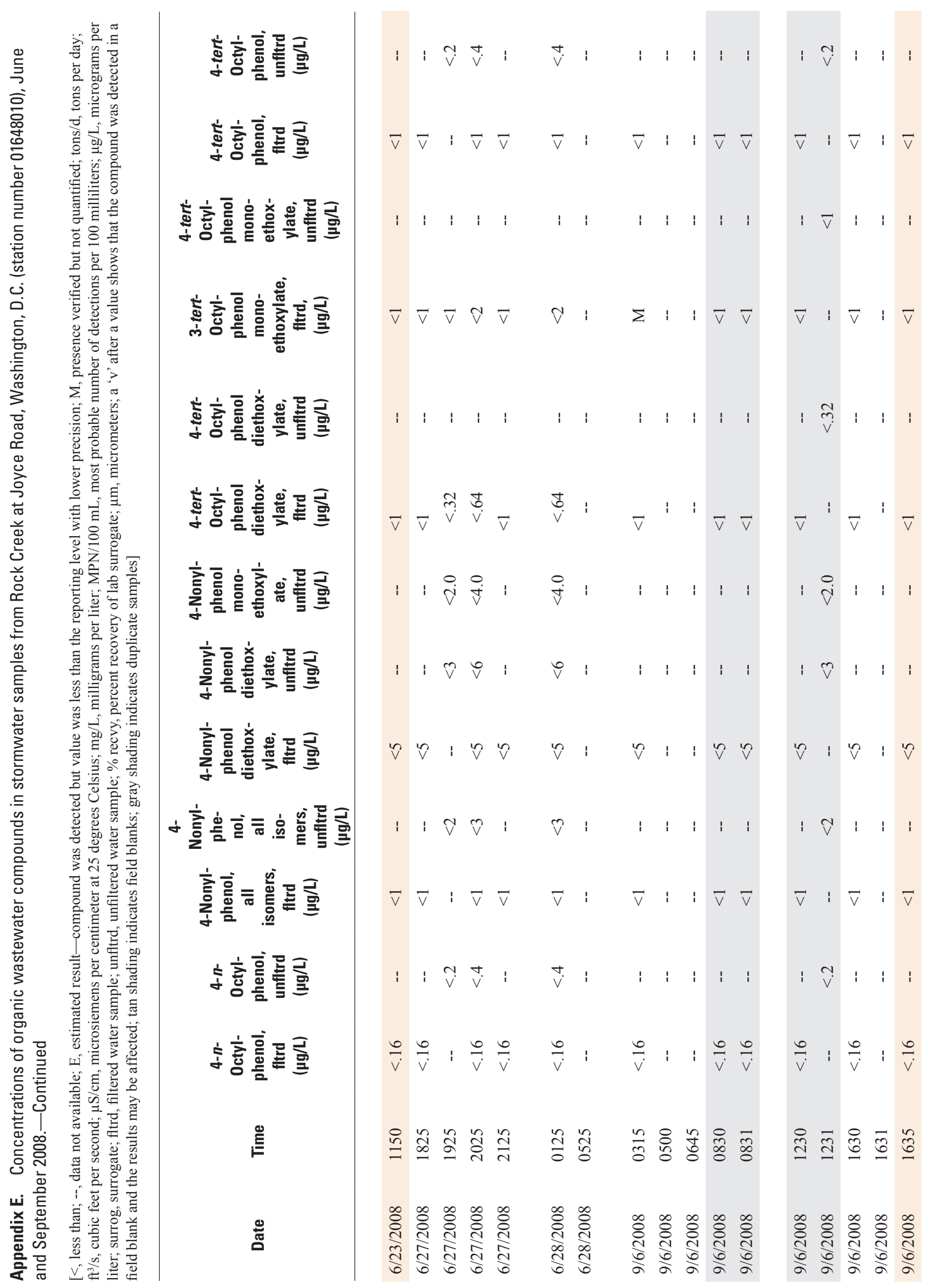




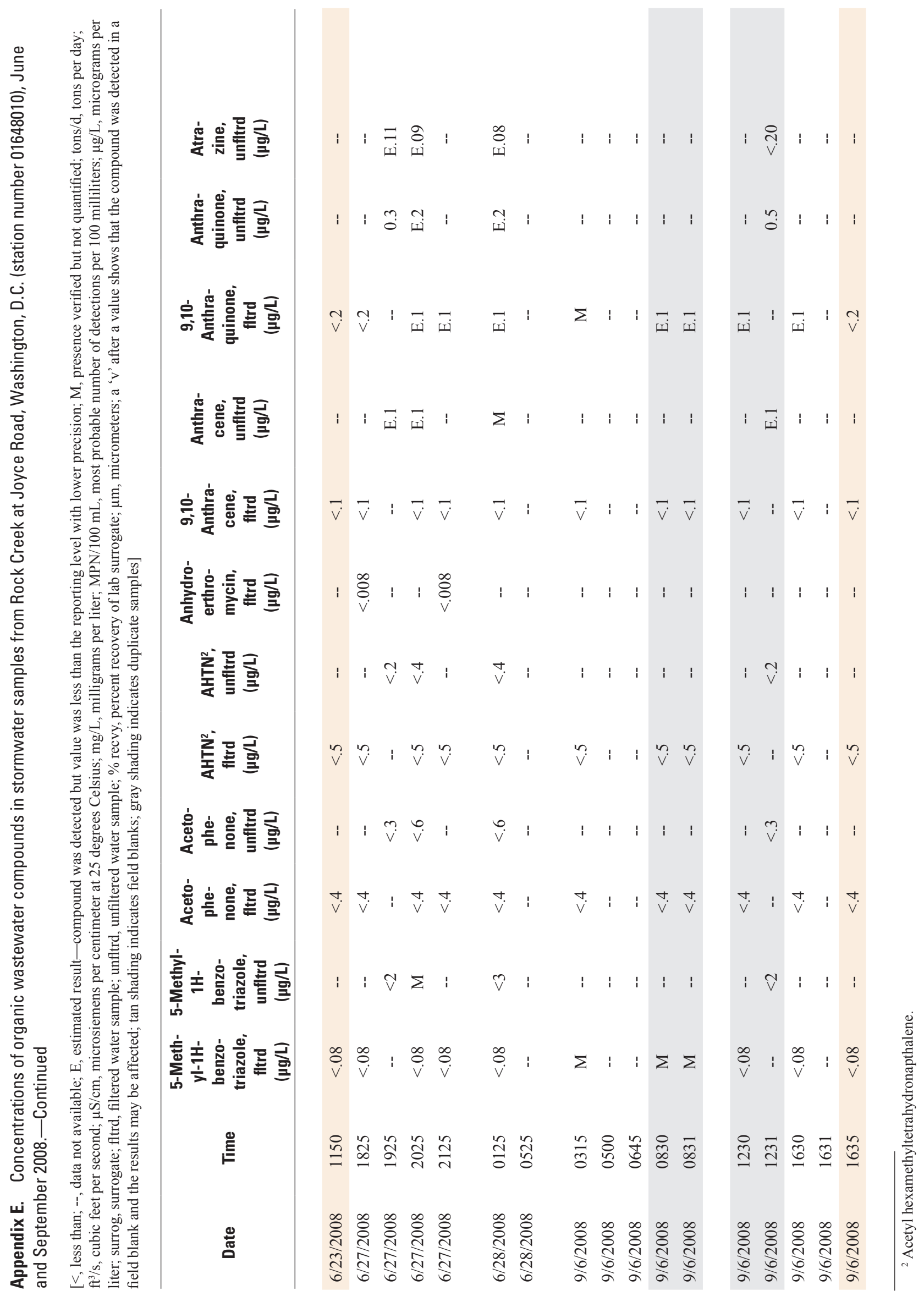




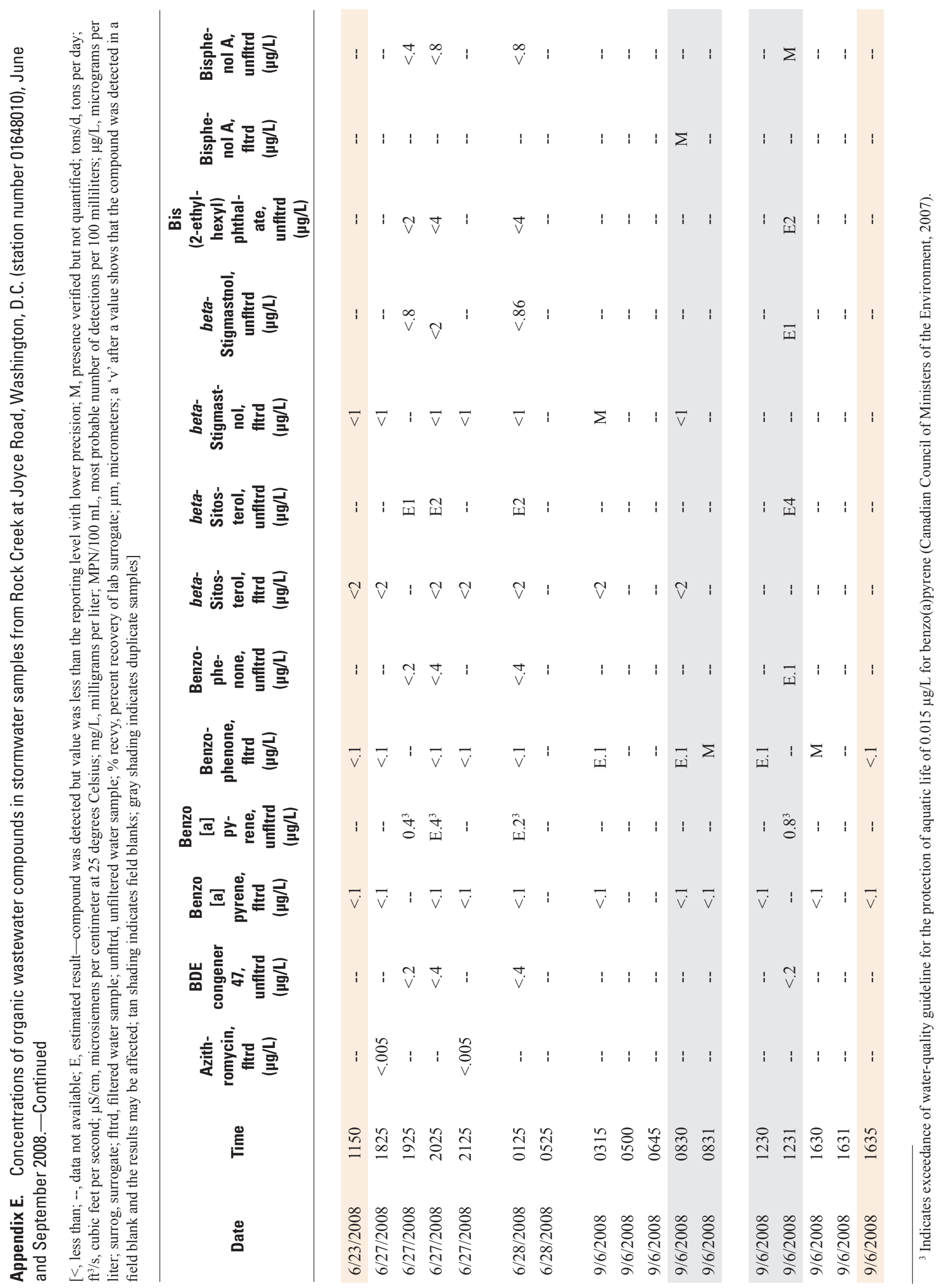




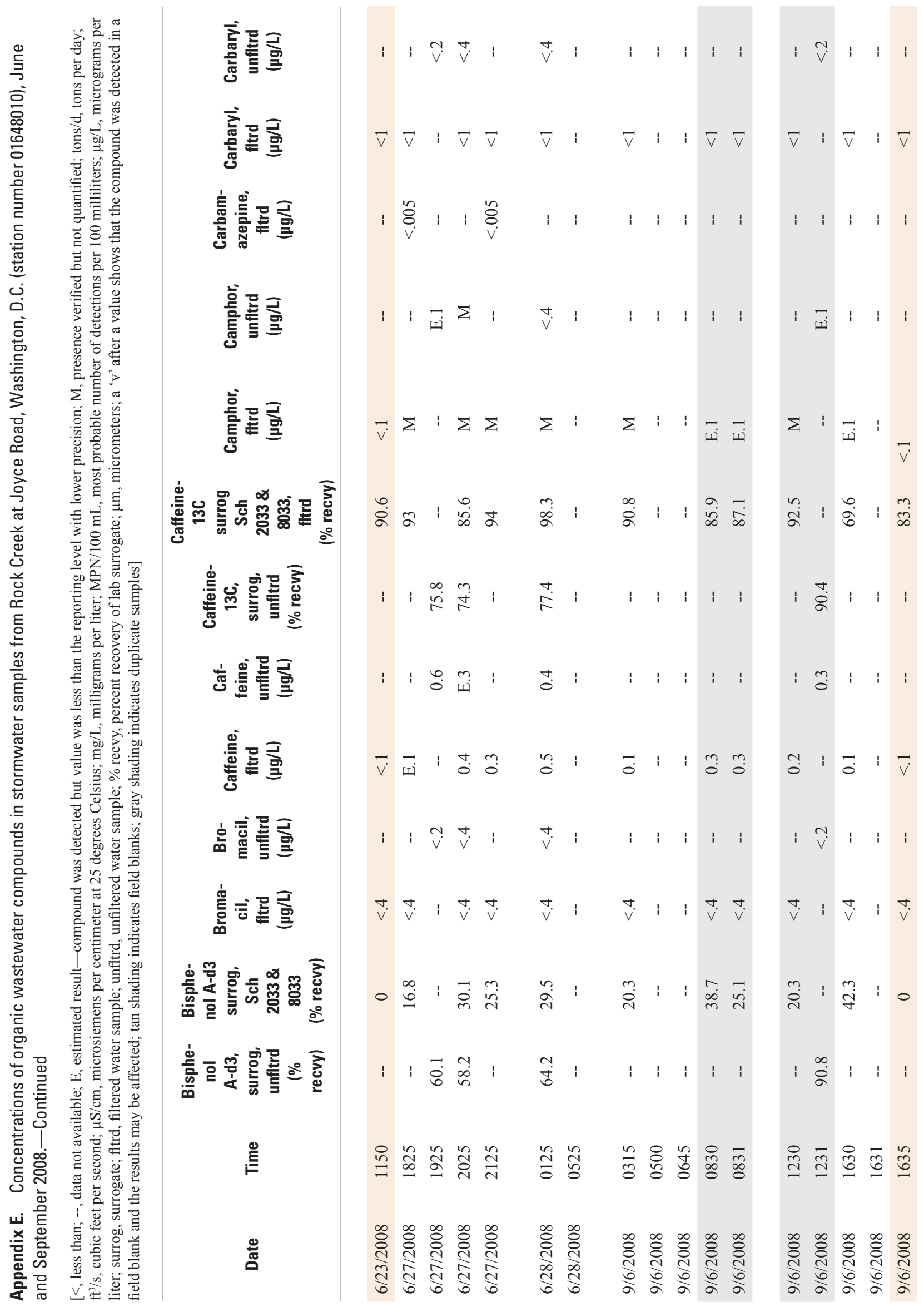




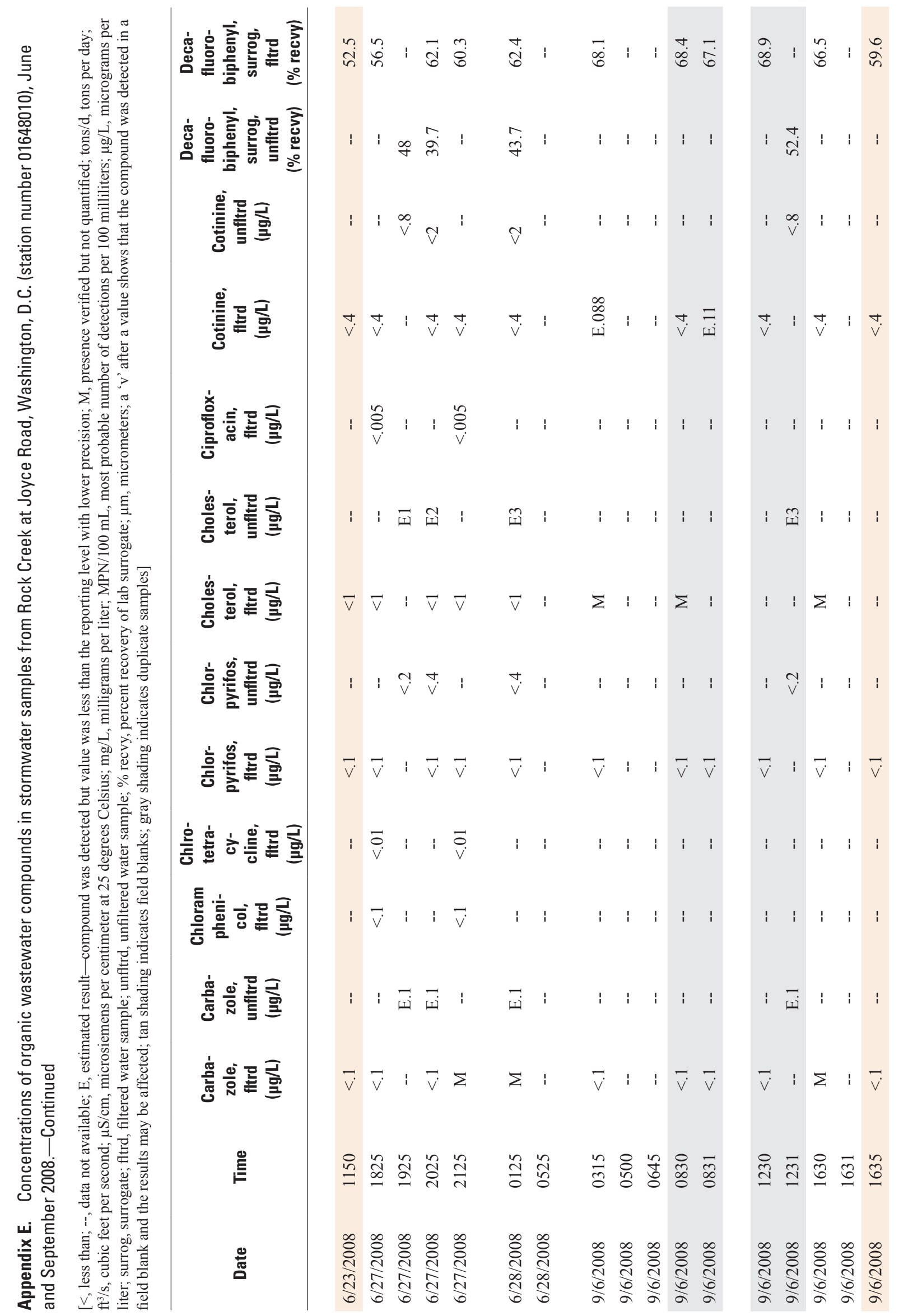




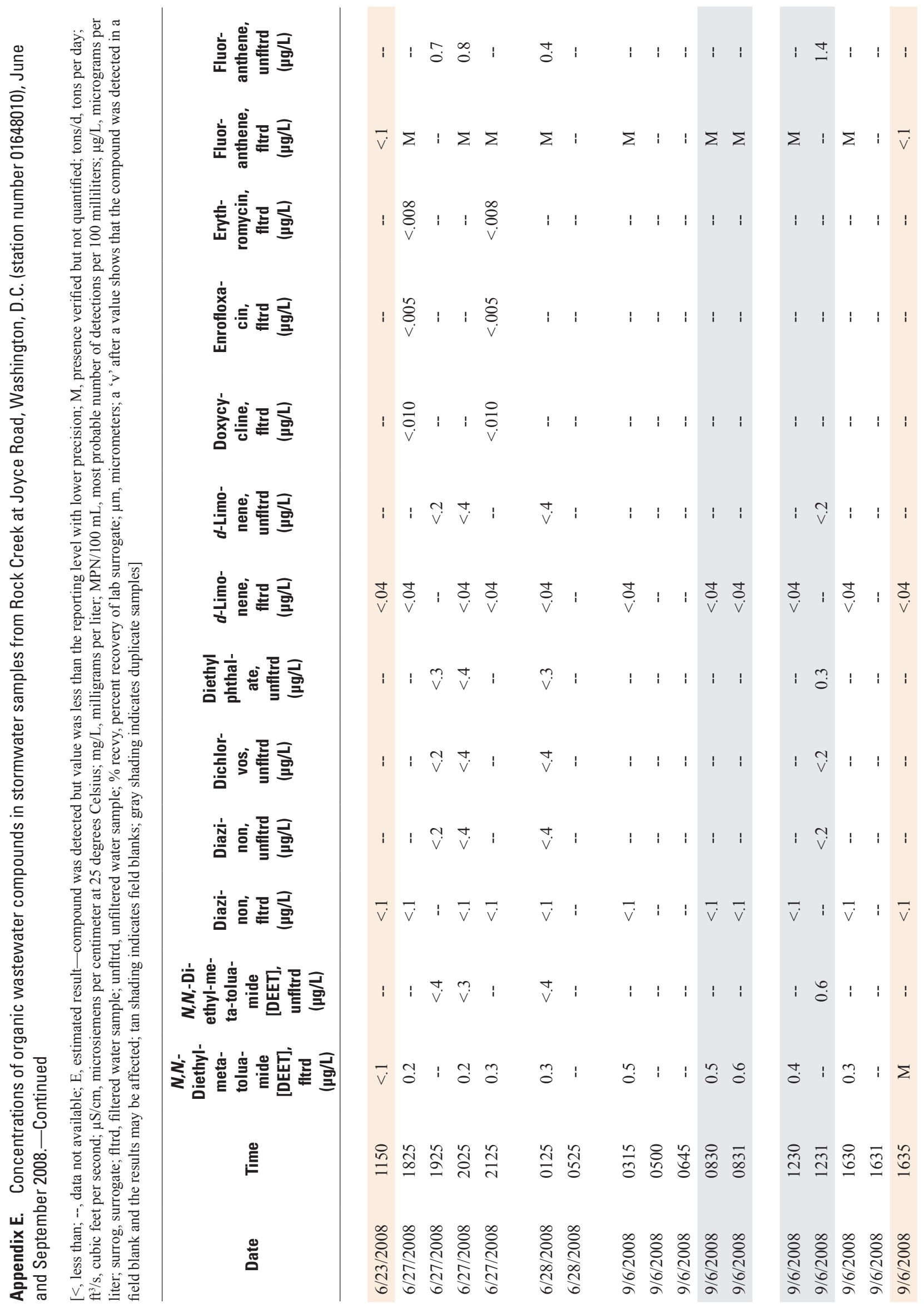




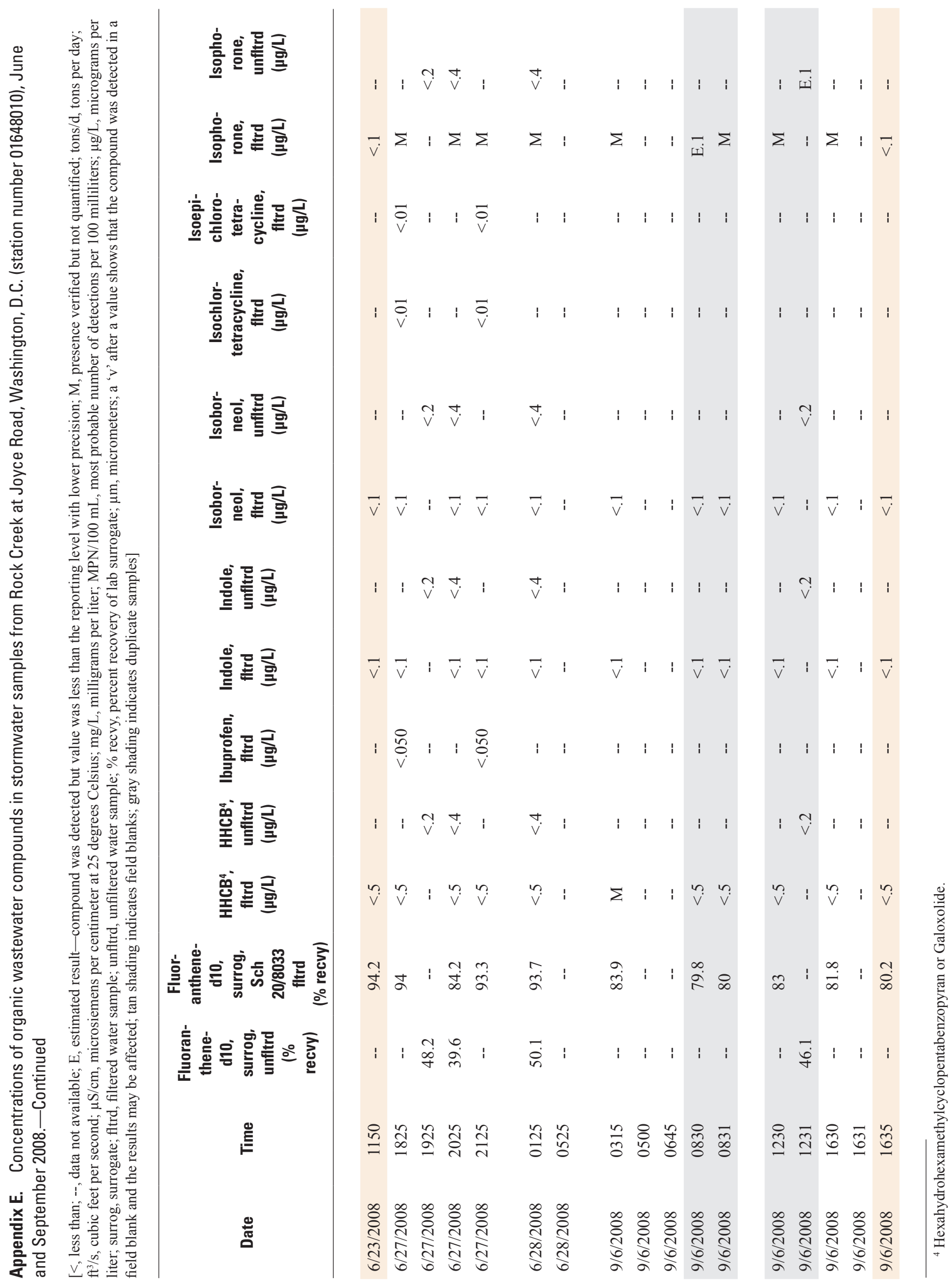




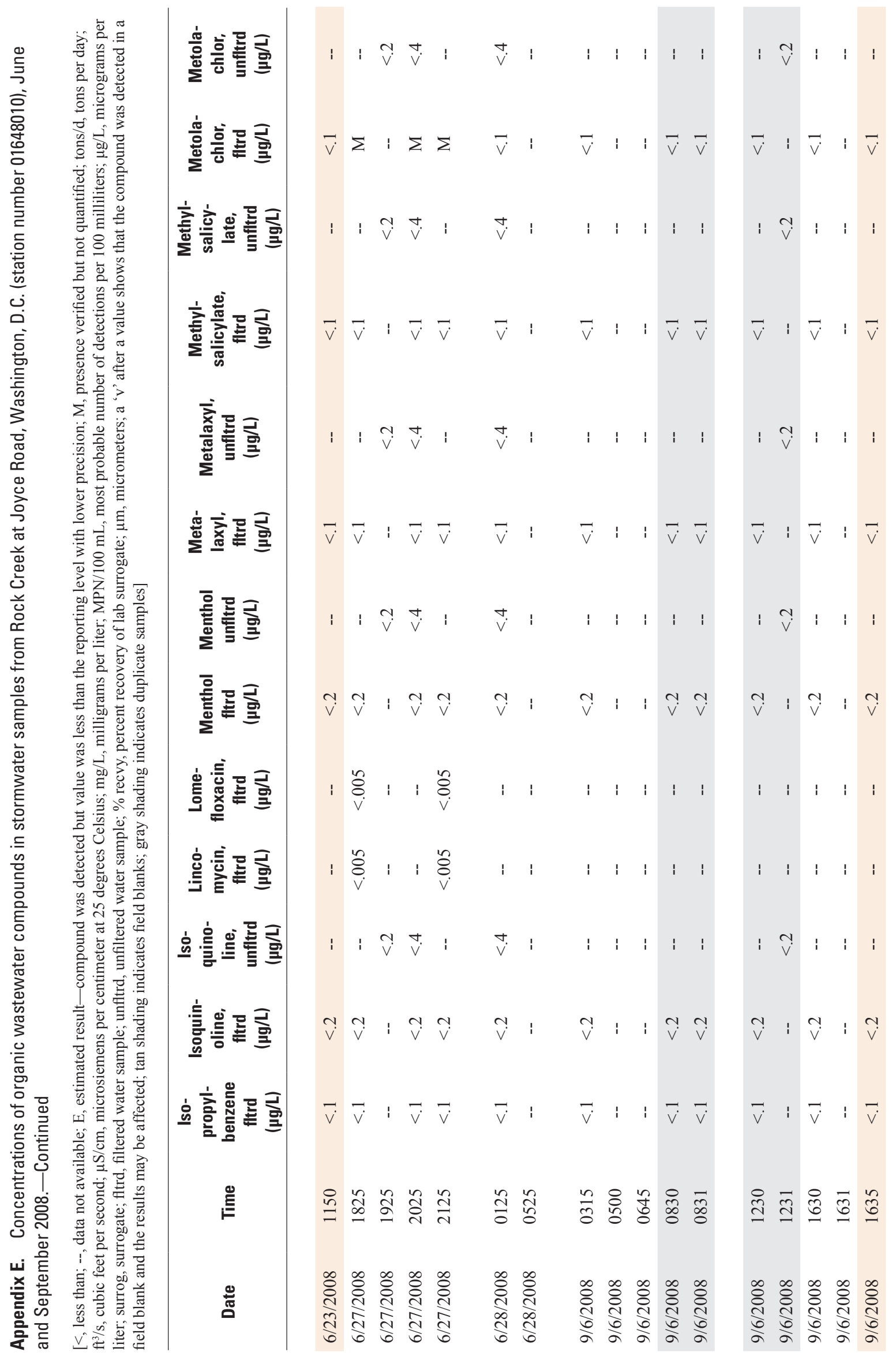




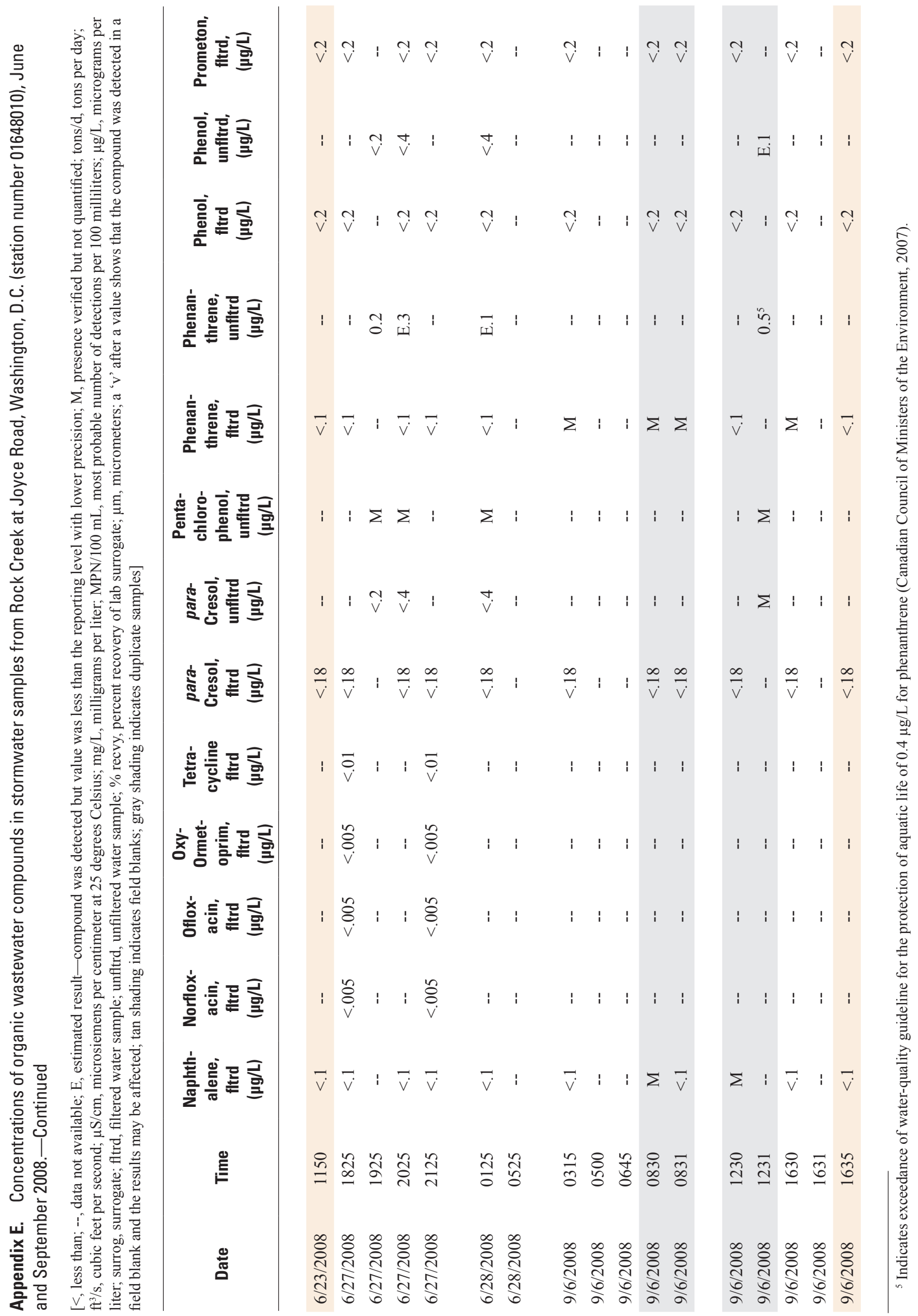




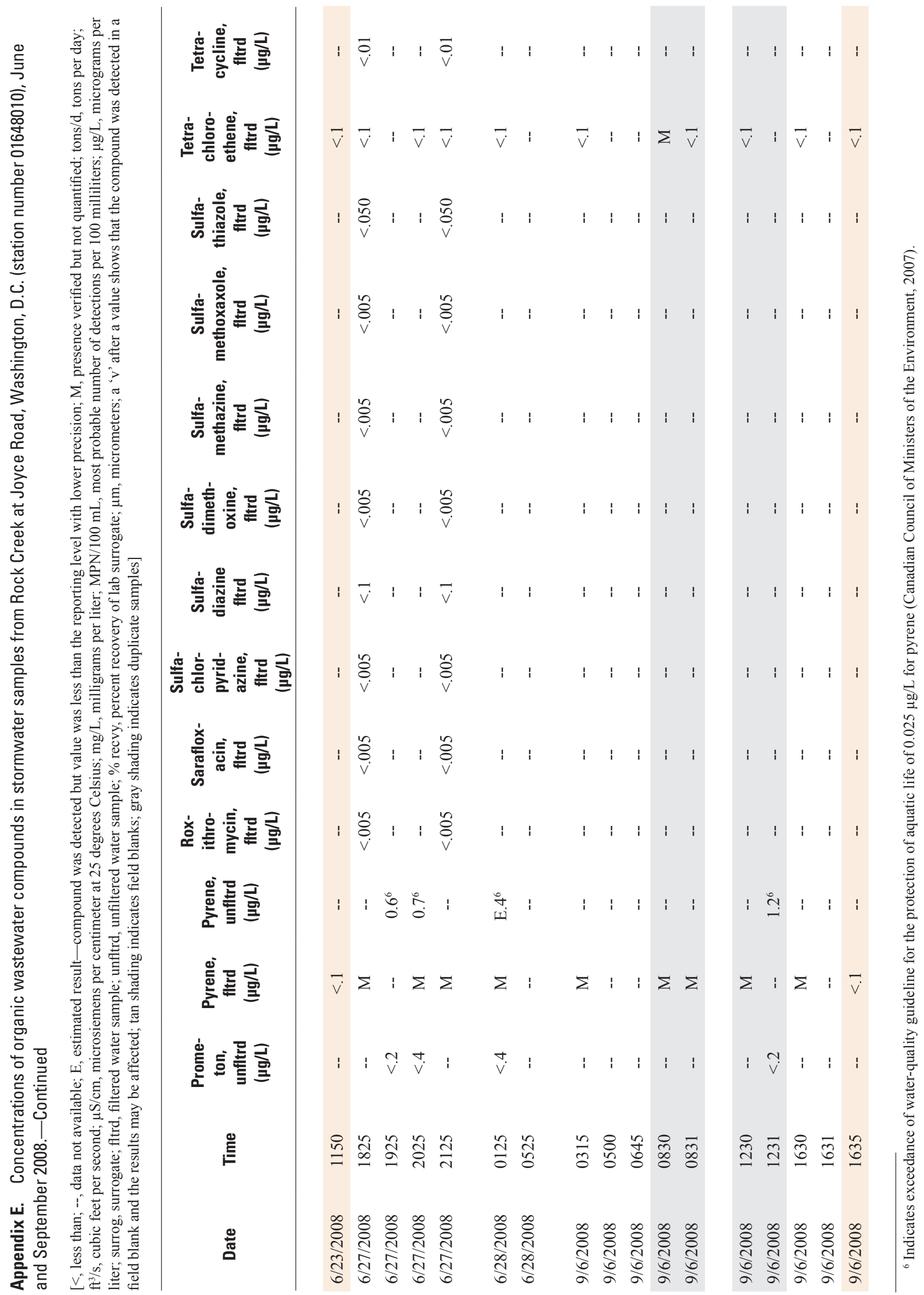




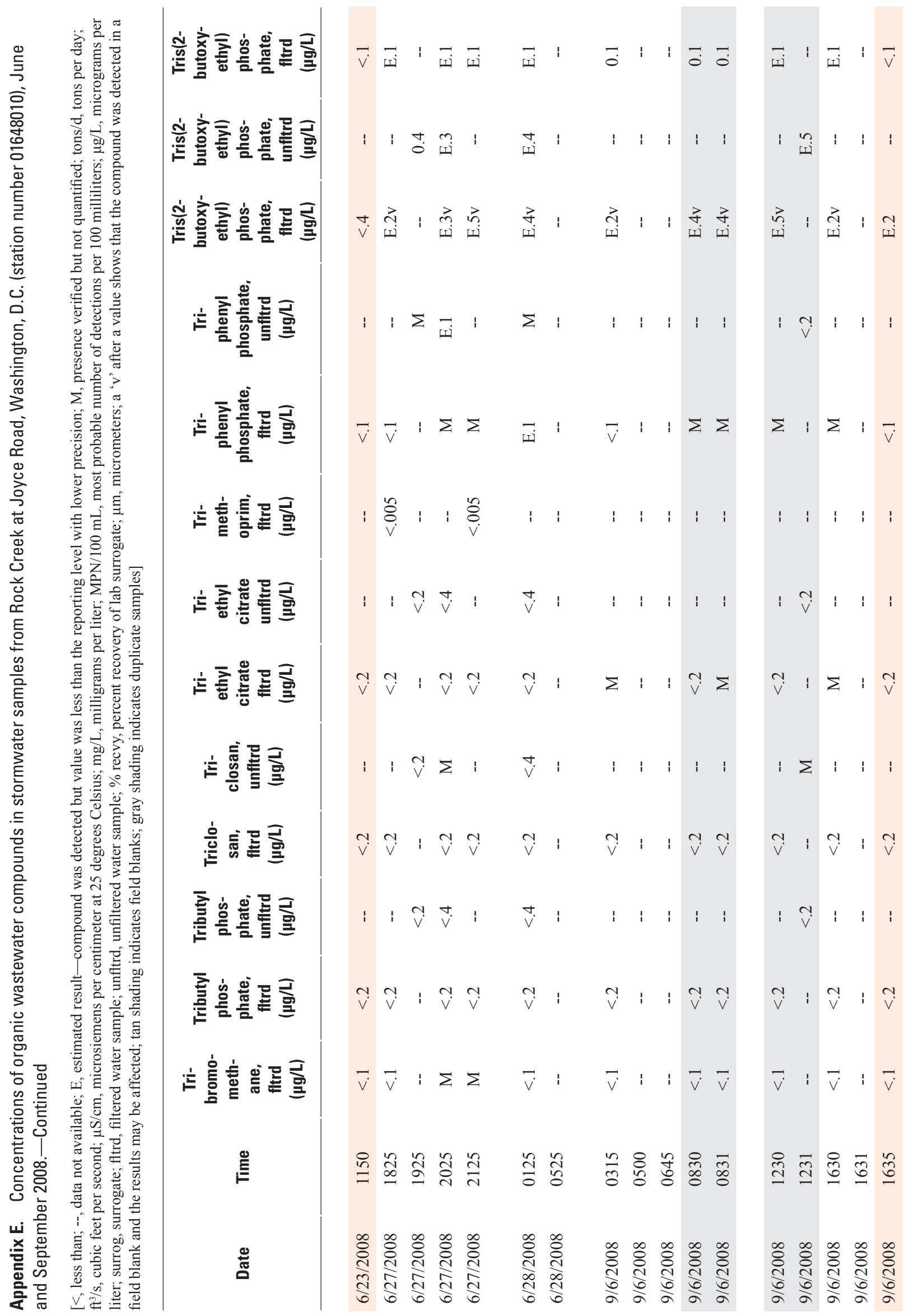




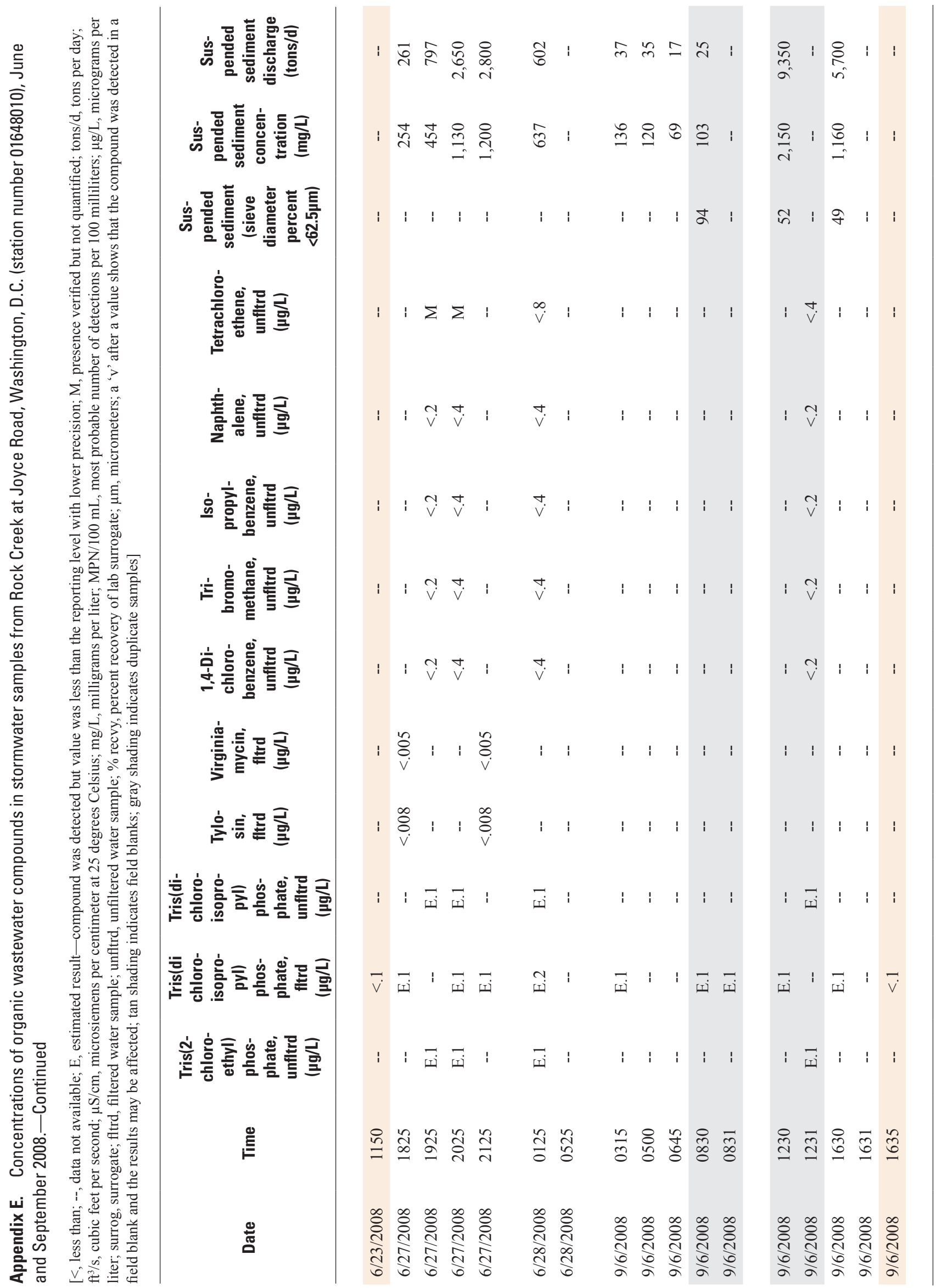




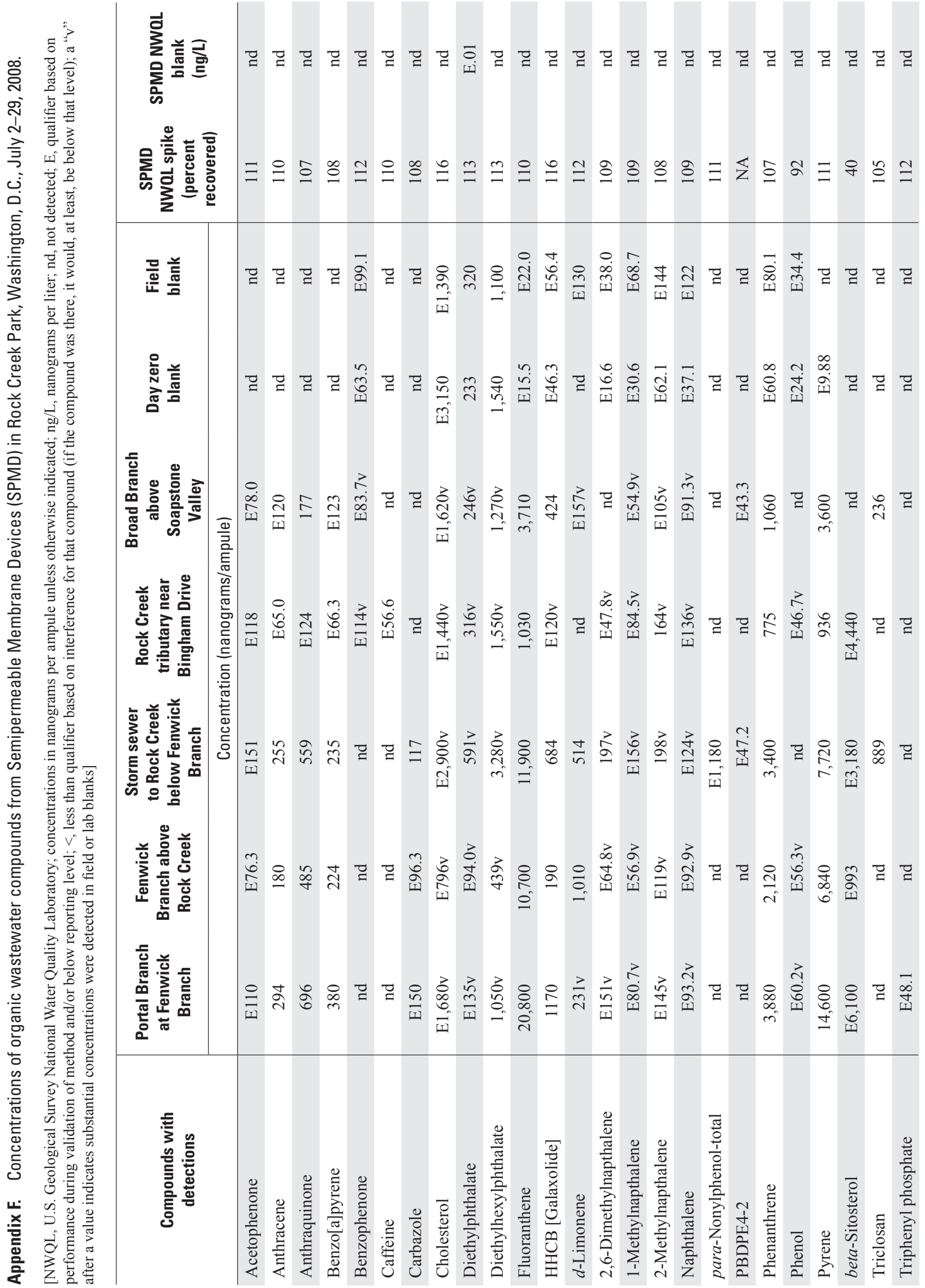




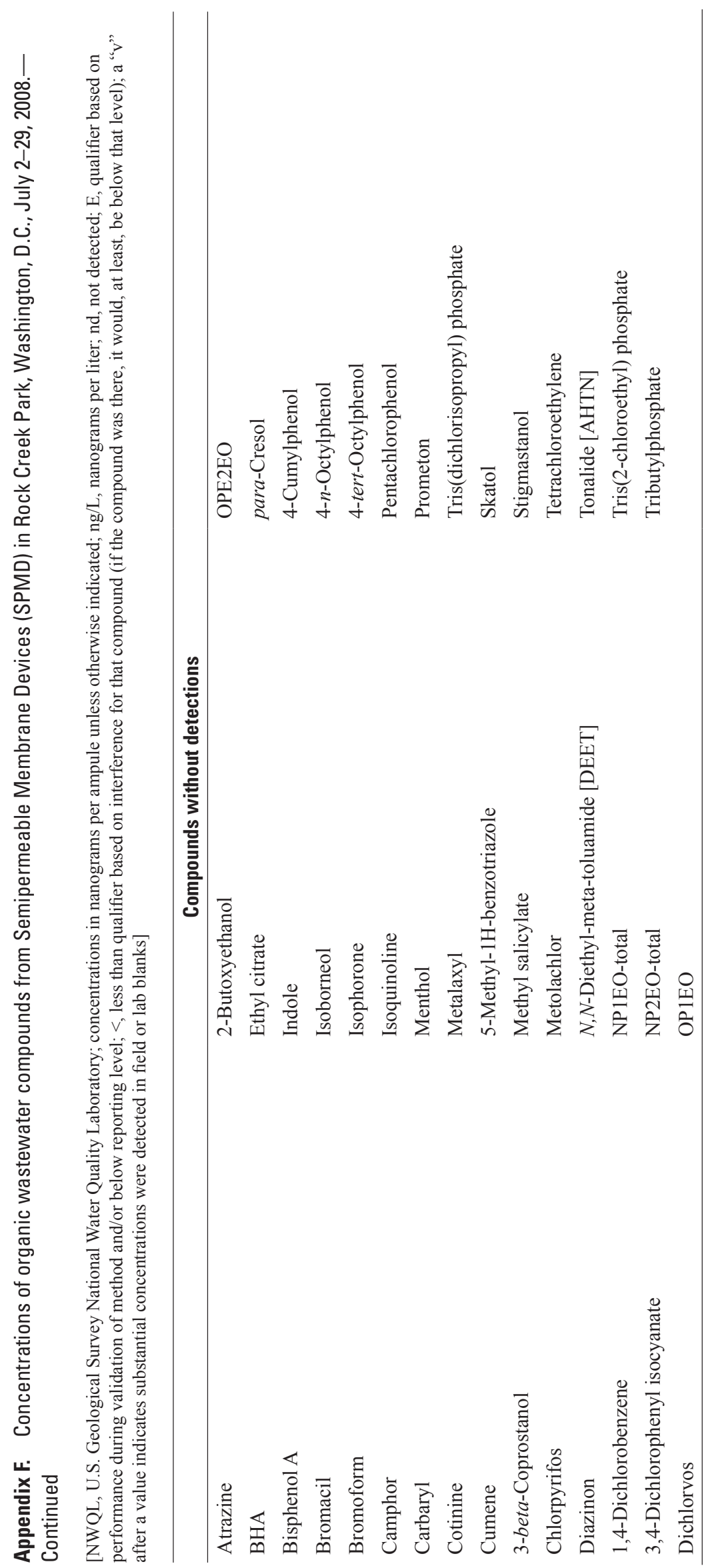




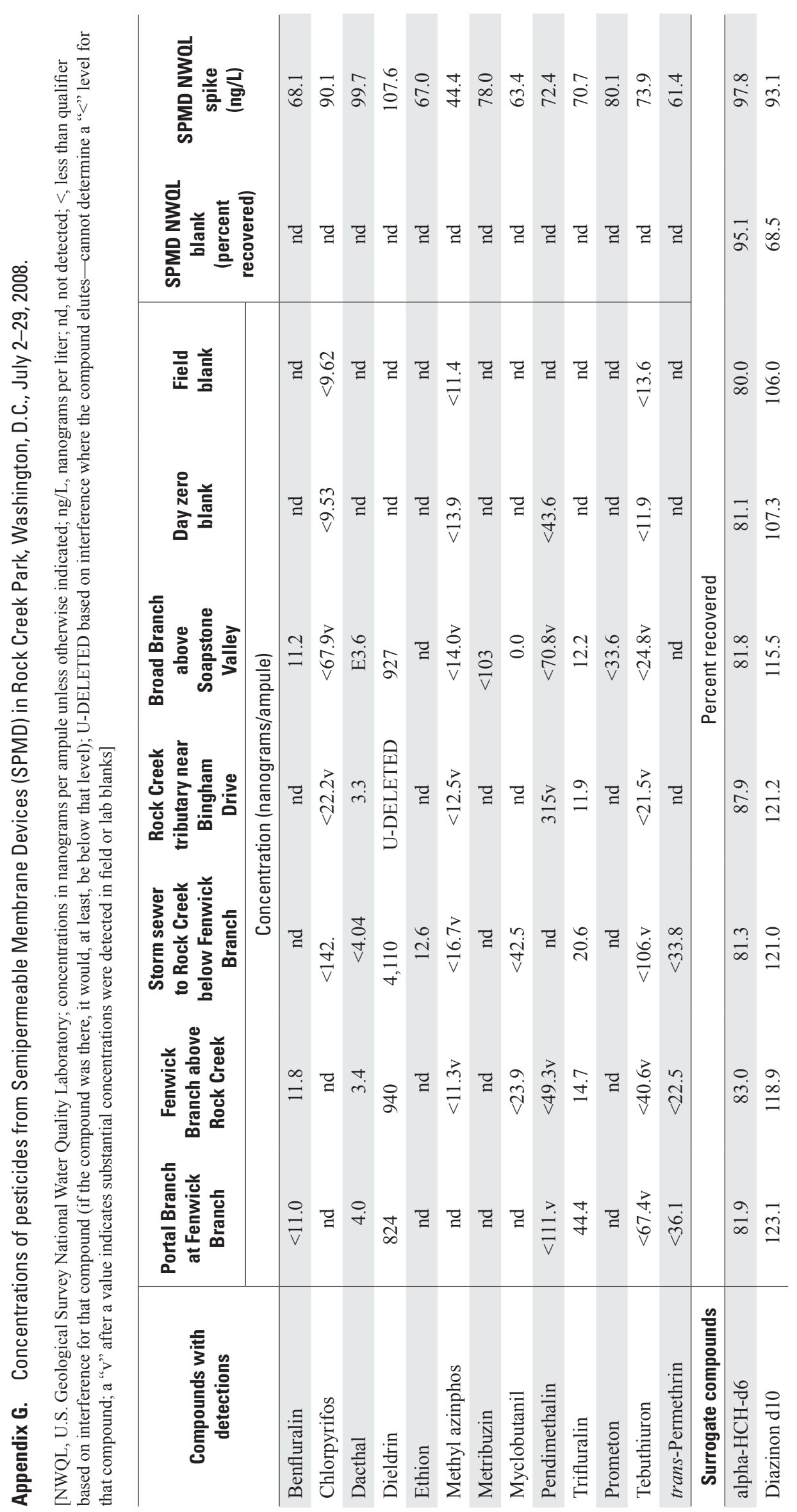




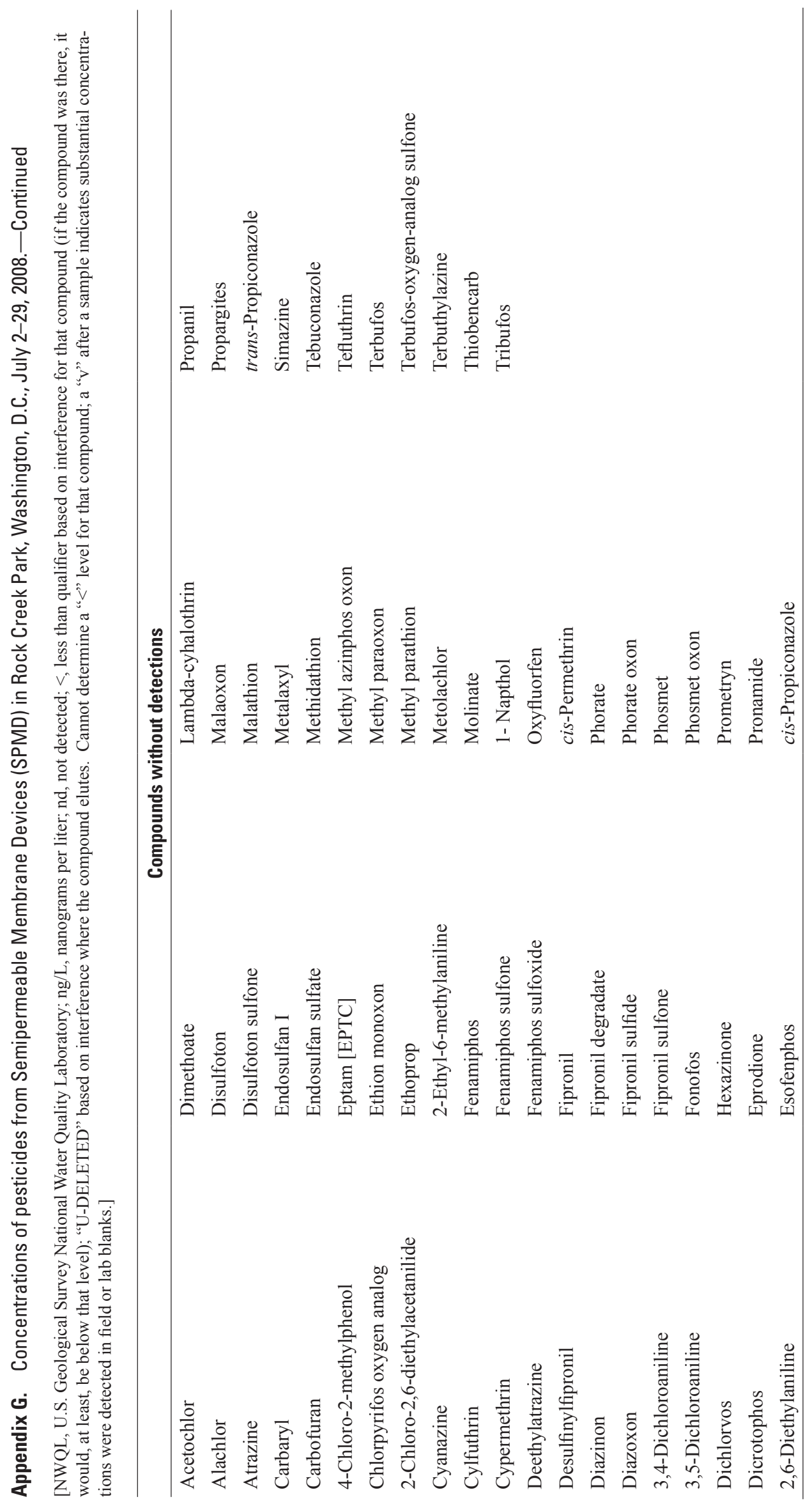


Prepared by USGS West Trenton Publishing Service Center. Edited by Valerie M. Gaine.

Graphics and layout by Timothy W. Auer.

For additional information, contact:

Director, MD-DE-DC Water Science Center

U.S. Geological Survey

5522 Research Park Drive

Baltimore, MD 21228

or visit our Web site at: http://md.water.usgs.gov 
